\title{
Chlorine partitioning near the polar vortex edge observed with ground-based FTIR and satellites at Syowa Station, Antarctica, in 2007 and 2011
}

\author{
Hideaki Nakajima $^{1,2}$, Isao Murata ${ }^{2}$, Yoshihiro Nagahama ${ }^{1}$, Hideharu Akiyoshi ${ }^{1}$, Kosuke Saeki ${ }^{2, a}$, Takeshi Kinase ${ }^{3}$, \\ Masanori Takeda $^{2}$, Yoshihiro Tomikawa ${ }^{4,5}$, Eric Dupuy ${ }^{1}$, and Nicholas B. Jones ${ }^{6}$ \\ ${ }^{1}$ National Institute for Environmental Studies, Tsukuba, Ibaraki, 305-8506, Japan \\ ${ }^{2}$ Graduate School of Environmental Studies, Tohoku University, Sendai, Miyagi, 980-8572, Japan \\ ${ }^{3}$ Meteorological Research Institute, Tsukuba, Ibaraki, 305-0052, Japan \\ ${ }^{4}$ National Institute of Polar Research, Tachikawa, Tokyo, 190-8518, Japan \\ ${ }^{5}$ The Graduate University for Advanced Studies, Tachikawa, Tokyo, 190-8518, Japan \\ ${ }^{6}$ University of Wollongong, Wollongong, New South Wales, 2522, Australia \\ anow at: Weathernews Inc., Chiba, 261-0023, Japan
}

Correspondence: Hideaki Nakajima (nakajima@nies.go.jp)

Received: 10 May 2019 - Discussion started: 12 June 2019

Revised: 3 December 2019 - Accepted: 10 December 2019 - Published: 27 January 2020

\begin{abstract}
We retrieved lower stratospheric vertical profiles of $\mathrm{O}_{3}, \mathrm{HNO}_{3}$, and $\mathrm{HCl}$ from solar spectra taken with a ground-based Fourier transform infrared spectrometer (FTIR) installed at Syowa Station, Antarctica $\left(69.0^{\circ} \mathrm{S}\right.$, $39.6^{\circ} \mathrm{E}$ ), from March to December 2007 and September to November 2011. This was the first continuous measurement of chlorine species throughout the ozone hole period from the ground in Antarctica. We analyzed temporal variation of these species combined with $\mathrm{ClO}, \mathrm{HCl}$, and $\mathrm{HNO}_{3}$ data taken with the Aura MLS (Microwave Limb Sounder) satellite sensor and $\mathrm{ClONO}_{2}$ data taken with the Envisat MIPAS (the Michelson Interferometer for Passive Atmospheric Sounding) satellite sensor at 18 and $22 \mathrm{~km}$ over Syowa Station. An $\mathrm{HCl}$ and $\mathrm{ClONO}_{2}$ decrease occurred from the end of May at both 18 and $22 \mathrm{~km}$, and eventually, in early winter, both $\mathrm{HCl}$ and $\mathrm{ClONO}_{2}$ were almost depleted. When the sun returned to Antarctica in spring, enhancement of $\mathrm{ClO}$ and gradual $\mathrm{O}_{3}$ destruction were observed. During the $\mathrm{ClO}$-enhanced period, a negative correlation between $\mathrm{ClO}$ and $\mathrm{ClONO}_{2}$ was observed in the time series of the data at Syowa Station. This negative correlation was associated with the relative distance between Syowa Station and the edge of the polar vortex. We used MIROC3.2 chemistry-climate model (CCM) results to investigate the behavior of whole chlorine and related species inside the polar vortex and the boundary region in more de-
\end{abstract}

tail. From CCM model results, the rapid conversion of chlorine reservoir species $\left(\mathrm{HCl}\right.$ and $\left.\mathrm{ClONO}_{2}\right)$ into $\mathrm{Cl}_{2}$, gradual conversion of $\mathrm{Cl}_{2}$ into $\mathrm{Cl}_{2} \mathrm{O}_{2}$, increase in $\mathrm{HOCl}$ in the winter period, increase in $\mathrm{ClO}$ when sunlight became available, and conversion of $\mathrm{ClO}$ into $\mathrm{HCl}$ were successfully reproduced. The $\mathrm{HCl}$ decrease in the winter polar vortex core continued to occur due to both transport of $\mathrm{ClONO}_{2}$ from the subpolar region to higher latitudes, providing a flux of $\mathrm{ClONO}_{2}$ from more sunlit latitudes into the polar vortex, and the heterogeneous reaction of $\mathrm{HCl}$ with $\mathrm{HOCl}$. The temporal variation of chlorine species over Syowa Station was affected by both heterogeneous chemistries related to polar stratospheric cloud (PSC) occurrence inside the polar vortex and transport of a $\mathrm{NO}_{x}$-rich air mass from the polar vortex boundary region, which can produce additional $\mathrm{ClONO}_{2}$ by reaction of $\mathrm{ClO}$ with $\mathrm{NO}_{2}$. The deactivation pathways from active chlorine into reservoir species $\left(\mathrm{HCl}\right.$ and/or $\left.\mathrm{ClONO}_{2}\right)$ were confirmed to be highly dependent on the availability of ambient $\mathrm{O}_{3}$. At $18 \mathrm{~km}$, where most ozone was depleted, most $\mathrm{ClO}$ was converted to $\mathrm{HCl}$. At $22 \mathrm{~km}$ where some $\mathrm{O}_{3}$ was available, an additional increase in $\mathrm{ClONO}_{2}$ from the prewinter value occurred, similar to the Arctic. 


\section{Introduction}

Discussion of the detection of the recovery of the Antarctic ozone hole as the result of chlorofluorocarbon (CFC) regulations has been attracting attention. The occurrence of the Antarctic ozone hole is predicted to continue at least until the middle of this century. The world's leading chemistryclimate models (CCMs) indicate that the multimodel mean time series of the springtime Antarctic total column ozone will return to 1980 levels shortly after the midcentury (about 2060) (WMO, 2019). In fact, the recovery time predicted by CCMs has a large uncertainty, and the observed ozone hole magnitude also shows year-to-year variability (e.g., see Figs. 4-6 in WMO, 2019). Although Solomon et al. (2016) and de Laat et al. (2017) reported signs of healing in the Antarctic ozone layer only in September, there is no statistically conclusive report on the Antarctic ozone hole recovery (Yang et al., 2008; Kuttippurath et al., 2010; WMO, 2019).

To understand ozone depletion processes in polar regions, understanding the behavior and partitioning of active chlorines $\left(\mathrm{ClO}_{x}=\mathrm{Cl}+\mathrm{Cl}_{2}+\mathrm{ClO}+\mathrm{ClOO}+\mathrm{Cl}_{2} \mathrm{O}_{2}\right)$ and chlorine reservoirs $\left(\mathrm{HCl}\right.$ and $\left.\mathrm{ClONO}_{2}\right)$ is crucial. Recently, the importance of $\mathrm{ClONO}_{2}$ was reviewed by von Clarmann and Johansson (2018). The chlorine reservoir is converted to active chlorine that destroys ozone on polar stratospheric clouds (PSCs) and/or cold binary sulfate through heterogeneous reactions:

$$
\begin{aligned}
& \mathrm{ClONO}_{2}(\mathrm{~g})+\mathrm{HCl}(\mathrm{s}, \mathrm{l}) \rightarrow \mathrm{Cl}_{2}(\mathrm{~g})+\mathrm{HNO}_{3}, \\
& \mathrm{ClONO}_{2}(\mathrm{~g})+\mathrm{H}_{2} \mathrm{O}(\mathrm{s}, \mathrm{l}) \rightarrow \mathrm{HOCl}(\mathrm{g})+\mathrm{HNO}_{3},
\end{aligned}
$$

where g, s, and 1 represent the gas, solid, and liquid phases, respectively (Solomon et al., 1986; Solomon, 1999; Drdla and Müller, 2012; Wegner et al., 2012; Nakajima et al., 2016).

Heterogeneous reactions,

$$
\begin{aligned}
& \mathrm{N}_{2} \mathrm{O}_{5}(\mathrm{~g})+\mathrm{HCl}(\mathrm{s}, \mathrm{l}) \rightarrow \mathrm{ClNO}_{2}(\mathrm{~g})+\mathrm{HNO}_{3} \\
& \mathrm{HOCl}(\mathrm{g})+\mathrm{HCl}(\mathrm{s}, 1) \rightarrow \mathrm{Cl}_{2}(\mathrm{~g})+\mathrm{H}_{2} \mathrm{O}
\end{aligned}
$$

are responsible for additional chlorine activation. When solar illumination is available, $\mathrm{Cl}_{2}, \mathrm{HOCl}$, and $\mathrm{ClNO}_{2}$ are photolyzed to produce chlorine atoms by reactions

$$
\begin{aligned}
& \mathrm{Cl}_{2}+h v \rightarrow \mathrm{Cl}+\mathrm{Cl}, \\
& \mathrm{HOCl}+h v \rightarrow \mathrm{Cl}+\mathrm{OH}, \\
& \mathrm{ClNO}_{2}+h v \rightarrow \mathrm{Cl}+\mathrm{NO}_{2} .
\end{aligned}
$$

The yielded chlorine atoms then start to destroy ozone catalytically through reactions (Canty et al., 2016):

$$
\begin{aligned}
& \mathrm{Cl}+\mathrm{O}_{3} \rightarrow \mathrm{ClO}+\mathrm{O}_{2}, \\
& \mathrm{ClO}+\mathrm{ClO}+M \rightarrow \mathrm{Cl}_{2} \mathrm{O}_{2}+M, \\
& \mathrm{Cl}_{2} \mathrm{O}_{2}+h v \rightarrow \mathrm{Cl}+\mathrm{ClOO}, \\
& \mathrm{ClOO}+M \rightarrow \mathrm{Cl}+\mathrm{O}_{2}+M .
\end{aligned}
$$

There are three types of PSCs, i.e., nitric acid trihydrate (NAT), supercooled ternary solution (STS), and ice PSCs. When the stratospheric temperatures get warmer than NAT saturation temperature (about $195 \mathrm{~K}$ at $50 \mathrm{hPa}$ ) and no PSCs are present, deactivation of chlorine starts to occur. Reformation of $\mathrm{ClONO}_{2}$ and $\mathrm{HCl}$ mainly occurs through reactions (Santee et al., 2008; Grooß et al., 2011; Müller et al., 2018)

$$
\begin{aligned}
& \mathrm{ClO}+\mathrm{NO}_{2}+M \rightarrow \mathrm{ClONO}_{2}+M, \\
& \mathrm{Cl}+\mathrm{CH}_{4} \rightarrow \mathrm{HCl}+\mathrm{CH}_{3}, \\
& \mathrm{CH}_{2} \mathrm{O}+\mathrm{Cl} \rightarrow \mathrm{HCl}+\mathrm{CHO} .
\end{aligned}
$$

The reformation of $\mathrm{ClONO}_{2}$ by Reaction (R12) from active chlorine is much faster than that of $\mathrm{HCl}$ by Reactions (R13) and (R14) if enough $\mathrm{NO}_{x}$ are available (Mellqvist et al., 2002; Dufour et al., 2006). But the formation rates of $\mathrm{ClONO}_{2}$ and $\mathrm{HCl}$ are also related to ozone concentration. Grooß et al. (1997) showed that $\mathrm{HCl}$ increases more rapidly in the Antarctic polar vortex than in the Arctic polar vortex due to lower ozone concentrations in the Antarctic polar vortex. Low ozone reduces the rate of Reaction (R8) and then the $\mathrm{Cl} / \mathrm{ClO}$ ratio increases. Low ozone also reduces the rate of the following reaction:

$\mathrm{NO}+\mathrm{O}_{3} \rightarrow \mathrm{NO}_{2}+\mathrm{O}_{2}$.

This makes the $\mathrm{NO} / \mathrm{NO}_{2}$ ratio high and increases the $\mathrm{Cl} / \mathrm{ClO}$ ratio using the following reaction:

$\mathrm{ClO}+\mathrm{NO} \rightarrow \mathrm{Cl}+\mathrm{NO}_{2}$.

A high $\mathrm{Cl} / \mathrm{ClO}$ ratio leads to rapid $\mathrm{HCl}$ formation by $\mathrm{Re}$ actions (R13) and (R14) and reduces the formation ratio of $\mathrm{ClONO}_{2}$ by Reaction (R12) (Grooß et al., 2011; Müller et al., 2018).

The processes of deactivation of active chlorine are different between typical conditions in the Antarctic and those in the Arctic. In the Antarctic, the temperature cools below the NAT PSC existence threshold (about $195 \mathrm{~K}$ at $50 \mathrm{hPa}$ ) in the whole area of the polar vortex in all years, and almost complete denitrification and chlorine activation occur (WMO, 2007), followed by severe ozone depletion in spring. In the chlorine reservoir recovery phase, $\mathrm{HCl}$ is mainly formed by Reaction (R13) due to the lack of ozone (typically less than $0.5 \mathrm{ppmv}$ ) using the mechanism described in the previous paragraph (Grooß et al., 2011).

On the other hand, in the Arctic, typically less PSC formation occurs in the polar vortex due to generally higher stratospheric temperatures $(\sim 10-15 \mathrm{~K}$ on average) compared with that of Antarctica. Then only partial denitrification and chlorine activation occur in some years (Manney et al., 2011; WMO, 2014). In this case, some ozone and $\mathrm{NO}_{2}$ are available in the chlorine reservoir recovery phase. Therefore, the $\mathrm{ClONO}_{2}$ amount becomes higher than that of $\mathrm{HCl}$ after PSCs have disappeared due to the rapid Reaction (R12) (Michelsen 
et al., 1999; Santee et al., 2003), which results in an additional increase in $\mathrm{ClONO}_{2}$ than the prewinter value at the time of chlorine deactivation in spring (von Clarmann et al., 1993; Müller et al., 1994; Oelhaf et al., 1994). In this way, the partitioning of the chlorine reservoir in springtime is related to temperature, PSC amounts, ozone, and $\mathrm{NO}_{2}$ concentrations (Santee et al., 2008; Solomon et al., 2015).

In the polar regions, the ozone and related atmospheric trace gas species have been intensively monitored by several measurement techniques since the discovery of the ozone hole. These measurements consist of direct observations by high-altitude aircraft (e.g., Anderson et al., 1989; Ko et al., 1989; Tuck et al., 1995; Jaeglé et al., 1997; Bonne et al., 2000), remote-sensing observations by satellites (e.g., Müller et al., 1996; Michelsen et al., 1999; Höpfner et al., 2004; Dufour et al., 2006; Hayashida et al., 2007), remote-sensing observations of $\mathrm{OClO}$ using a UV-visible spectrometer from the ground (Solomon et al., 1987; Kreher et al., 1996), and remote-sensing observations of $\mathrm{ClO}$ by a microwave spectrometer from the ground (de Zafra et al., 1989). Within these observations, ground-based measurements have the characteristic of high temporal resolution. In addition, the Fourier transform infrared spectrometer (FTIR) has the capability of measuring several trace gas species at the same time or in a short time interval (Rinsland et al., 1988). In this paper, we show the results of ground-based FTIR observations of $\mathrm{O}_{3}$ and other trace gas species at Syowa Station in the Antarctic in 2007 and 2011, combined with satellite measurements of trace gas species from the Microwave Limb Sounder on board the Aura satellite (Aura MLS) and Michelson Interferometer for Passive Atmospheric Sounding on board the European Environmental Satellite (Envisat MIPAS), to show the temporal variation and partitioning of active chlorine $\left(\mathrm{ClO}_{x}\right)$ and chlorine reservoirs $\left(\mathrm{HCl}, \mathrm{ClONO}_{2}\right)$ from fall to spring during the ozone hole formation and dissipation period. In order to monitor the appearance of PSCs over Syowa Station, we used the Cloud-Aerosol Lidar with Orthogonal Polarization (CALIOP) data on board the Cloud-Aerosol Lidar and Infrared Pathfinder Satellite Observations (CALIPSO) satellite. The methods of FTIR and satellite measurements are described in Sect. 2. The validation of FTIR measurements is described in Sect. 3. The results of FTIR and satellite measurements and discussion on the behavior of active and inert chlorine species using the MIROC3.2 chemistry-climate model are described in Sect. 4.

\section{Measurements}

\subsection{FTIR measurements}

The Japanese Antarctic Syowa Station $\left(69.0^{\circ} \mathrm{S}, 39.6^{\circ} \mathrm{E}\right)$ was established in January 1957. Since then, several scientific observations related to meteorology, upper atmospheric physics, glaciology, biology, geology, seismology, etc. have been performed. The ozone hole was first detected by Dobson spectrometer and ozonesonde measurements from Syowa Station in 1982 (Chubachi, 1984) and by Dobson spectrometer measurements at Halley Bay (Farman et al., 1985). We installed a Bruker IFS-120M highresolution Fourier transform infrared spectrometer (FTIR) in the observation hut at Syowa Station in March 2007. This was the third high-resolution FTIR site in Antarctica in operation after the USA's South Pole Station $\left(90.0^{\circ} \mathrm{S}\right.$ ) (Goldman et al., 1983, 1987; Murcray et al., 1987), the USA's McMurdo Station, and New Zealand's Arrival Heights facility at the Scott Base station $\left(77.8^{\circ} \mathrm{S}, 166.7^{\circ} \mathrm{E}\right.$ ) (Farmer et al., 1987; Murcray et al., 1989; Kreher et al., 1996; Wood et al., 2002, 2004). The IFS-120M FTIR has a wavenumber resolution of $0.0035 \mathrm{~cm}^{-1}$, with two liquid-nitrogen-cooled detectors (with $\mathrm{InSb}$ and $\mathrm{HgCdTe}$ covering the frequency ranges 2000-5000 and 700-1300 $\mathrm{cm}^{-1}$, respectively) with six optical filters, and is fed by an external solar tracking system. One measurement takes about $10 \mathrm{~min}$. At least six spectra were taken per day, covering each filter region. Since Syowa Station is located at a relatively low latitude $\left(69.0^{\circ} \mathrm{S}\right) \mathrm{com}-$ pared with McMurdo or Scott Base stations $\left(77.8^{\circ} \mathrm{S}\right)$, there is an advantage of the short (about 1 month) polar night period, when we cannot measure atmospheric species using the sun as a light source. Since FTIR measurements at Syowa Station are possible from early spring (late July), FTIR can measure chemical species during ozone hole development. On the other hand, FTIR observations become possible only after September at McMurdo and Scott Base stations. Another advantage of Syowa Station is that it is sometimes located at the vortex boundary as well as inside and outside of the polar vortex, and this enables us to measure chemical species at different regions of polar chemistry related to the ozone hole. From March to December 2007, we made in total $78 \mathrm{~d}$ of FTIR measurements on sunny days. Another $19 \mathrm{~d}$ of FTIR measurements were performed from September to November 2011. After a few more measurements were performed in 2016, the FTIR was brought back to Japan in 2017. In Appendix A, Table A1 shows the days when FTIR measurements were made at Syowa Station with the information inside, in the boundary region, and outside of the polar vortex defined by the method described in Appendix B using ERA-Interim reanalysis data. Strahan et al. (2014) showed the year-to-year variation of $\mathrm{Cl}_{y}$ observed in the lower stratosphere of the Antarctic polar vortex. The $\mathrm{Cl}_{y}$ observed in 2007 ( $2.88 \mathrm{ppbv}$ ) was about $+4.3 \%$ more and that observed in 2011 ( $2.53 \mathrm{ppbv})$ was about $-5.2 \%$ less than the projected $\mathrm{Cl}_{y}$ from Newman et al. (2007) (2.76 ppbv for 2007 and $2.67 \mathrm{ppbv}$ for 2011).

The retrieval of the FTIR spectra was done with the SFIT2 version 3.92 program (Rinsland et al., 1998; Hase et al., 2004). SFIT2 retrieves a vertical profile of trace gases using an optimal estimation formulation of Rodgers (2000), implemented with a semiempirical method which was originally developed for microwave measurements (Parrish et al., 
1992; Connor et al., 1995). The SFIT2 forward model fully describes the FTIR instrument response, with absorption coefficients calculated using the algorithm of Norton and Rinsland (1991). The atmosphere is constructed with 47 layers from the ground to $100 \mathrm{~km}$, using the FSCATM (Gallery et al., 1983) program for atmospheric ray tracing to account for refractive bending. The retrieval parameters for each gas, typical vertical resolution, and typical mean degrees of freedom for signal (DOFS) are shown in Table 1. Temperature and pressure profiles between 0 and $30 \mathrm{~km}$ are taken by the rawinsonde observations flown from Syowa Station on the same day by the Japanese Meteorological Agency (JMA), while values between 30 and $100 \mathrm{~km}$ are taken from the COSPAR International Reference Atmosphere 1986 (CIRA86) standard atmosphere profile (Rees et al., 1990).

We retrieved vertical profiles of $\mathrm{O}_{3}, \mathrm{HCl}$, and $\mathrm{HNO}_{3}$ from the solar spectra. We used monthly averaged ozonesondes profiles $(0-30 \mathrm{~km})$ and Improved Limb Atmospheric Spectrometer-II (ILAS-II) (Nakajima, 2006; Nakajima et al., 2006; Sugita et al., 2006) profiles (30-100 km) for the a priori profiles of $\mathrm{O}_{3}$, monthly averaged profiles from ILASII for $\mathrm{HNO}_{3}$, and monthly averaged profiles from HALOE (Anderson et al., 2000) for HCl. We focus on the altitude range of $15-25 \mathrm{~km}$ in this study. Typical averaging kernels of the SFIT2 retrievals for $\mathrm{O}_{3}, \mathrm{HNO}_{3}$, and $\mathrm{HCl}$ are shown in Fig. 1a, b, and c, respectively.

\subsection{Satellite measurements}

The Earth Observing System (EOS) MLS on board the Aura satellite was launched on 15 July 2004 to monitor several atmospheric chemical species in the upper troposphere to mesosphere (Waters et al., 2006). The Aura orbit is sun-synchronous at $705 \mathrm{~km}$ altitude, with an inclination of $98^{\circ}, 13: 45$ ascending (north-going) Equator-crossing time, and $98.8 \mathrm{~min}$ period. Vertical profiles are measured every $\sim 165 \mathrm{~km}$ along the suborbital track, the horizontal resolution is $\sim 200-600 \mathrm{~km}$ along track and $\sim 3-10 \mathrm{~km}$ across track, and the vertical resolution is $\sim 3-4 \mathrm{~km}$ in the lowerto-middle stratosphere (Froidevaux et al., 2006). $\mathrm{ClO}, \mathrm{HCl}$, and $\mathrm{HNO}_{3}$ profiles used in this study were taken from Aura MLS version 4.2 data (Livesey et al., 2006, 2018; Santee et al., 2011; Ziemke et al., 2011). Only daytime ClO data were used for the analysis. The daily MLS data within $320 \mathrm{~km}$ distance between the measurement location and Syowa Station were selected.

MIPAS is a Fourier transform spectrometer sounding the thermal emission of the earth's atmosphere between 685 and $2410 \mathrm{~cm}^{-1}(14.6-4.15 \mu \mathrm{m})$ in limb geometry (Fischer and Oelhaf, 1996; Fischer et al., 2008). The maximum optical path difference of MIPAS is $20 \mathrm{~cm}$. The field of view of the instrument at the tangent points is about $3 \mathrm{~km}$ in the vertical and $30 \mathrm{~km}$ in the horizontal. In the standard observation mode in one limb scan, 17 tangent points are observed with nominal altitudes $6,9,12,15,18,21,24,27,30,33,36,39$,
$42,47,52,60$, and $68 \mathrm{~km}$. In this mode, about 73 limb scans are recorded per orbit. The measurements of each orbit cover nearly the complete latitude range from about $87^{\circ} \mathrm{S}$ to $89^{\circ} \mathrm{N}$. MIPAS was placed on board Envisat, which was launched on 1 March 2002, and was put into a polar sun-synchronous orbit at an altitude of about $800 \mathrm{~km}$ with an inclination of $98.55^{\circ}$ (von Clarmann et al., 2003). On its descending node, the satellite crosses the Equator at 10:00 local time. Envisat performs 14.3 orbits per day, which results in a good global coverage. The $\mathrm{ClONO}_{2}$ profiles which we used in this study were taken from Envisat MIPAS IMK/IAA version V5R_CLONO2_220 and V5R_CLONO2_222 (Höpfner et al., 2007). The daily MIPAS data within $320 \mathrm{~km}$ distance between the measurement location and Syowa Station were selected.

The CALIPSO satellite was launched on 28 April 2006. On the CALIPSO satellite, the CALIOP instrument was on board to monitor aerosols, clouds, and PSCs (Pitts et al., 2007). CALIOP is a two-wavelength, polarization-sensitive lidar that provides high-vertical-resolution profiles of the backscatter coefficient at 532 and $1064 \mathrm{~nm}$, as well as two orthogonal (parallel and perpendicular) polarization components at $532 \mathrm{~nm}$ (Winker et al., 2007). In order to monitor the appearance of PSCs over Syowa Station, the daily CALIOP PSC data (Pitts et al., 2007, 2009, 2011) within 320 km distance between the measurement location and Syowa Station were selected.

\section{Validation of retrieved profiles from FTIR spectra with other measurements}

We validated retrieved FTIR profiles of $\mathrm{O}_{3}$ with ozonesondes and Aura MLS version 3.3 data (Livesey et al., 2013) for 2007 measurements. Also, retrieved FTIR profiles of $\mathrm{HNO}_{3}$ and $\mathrm{HCl}$ were validated with Aura MLS data. We identified the nearest Aura MLS data from the distance between the Aura MLS tangent point and the point for the direction of the sun from Syowa Station at the time of the FTIR measurement at $20 \mathrm{~km}$. The spatial and temporal collocation criteria used were within a $300 \mathrm{~km}$ radius and $\pm 6 \mathrm{~h}$. The ozonesonde and Aura MLS profiles were interpolated onto a $1 \mathrm{~km}$ grid and then smoothed using a $5 \mathrm{~km}$ wide running mean.

Figure $2 \mathrm{a}-\mathrm{b}$ show absolute and relative differences of $\mathrm{O}_{3}$ profiles retrieved from FTIR measurements and those from model $1 \mathrm{Z}$ ECC-type ozonesonde measurements, respectively, calculated from 14 coincident measurements from 5 September to 17 December 2007. The typical precision and accuracy of the ECC-type ozone sondes are considered to be $\pm(3-5) \%$ and $\pm(4-5) \%$, respectively (Komhyr, 1986). We define the relative percentage difference $D$ as

$D(\%)=100 \cdot($ FTIR - sonde $) /(($ FTIR + sonde $) / 2)$.

The mean absolute difference between 15 and $25 \mathrm{~km}$ was within -0.02 to $0.40 \mathrm{ppmv}$. The mean relative difference $D$ 
Table 1. Retrieval parameters of SFIT2.

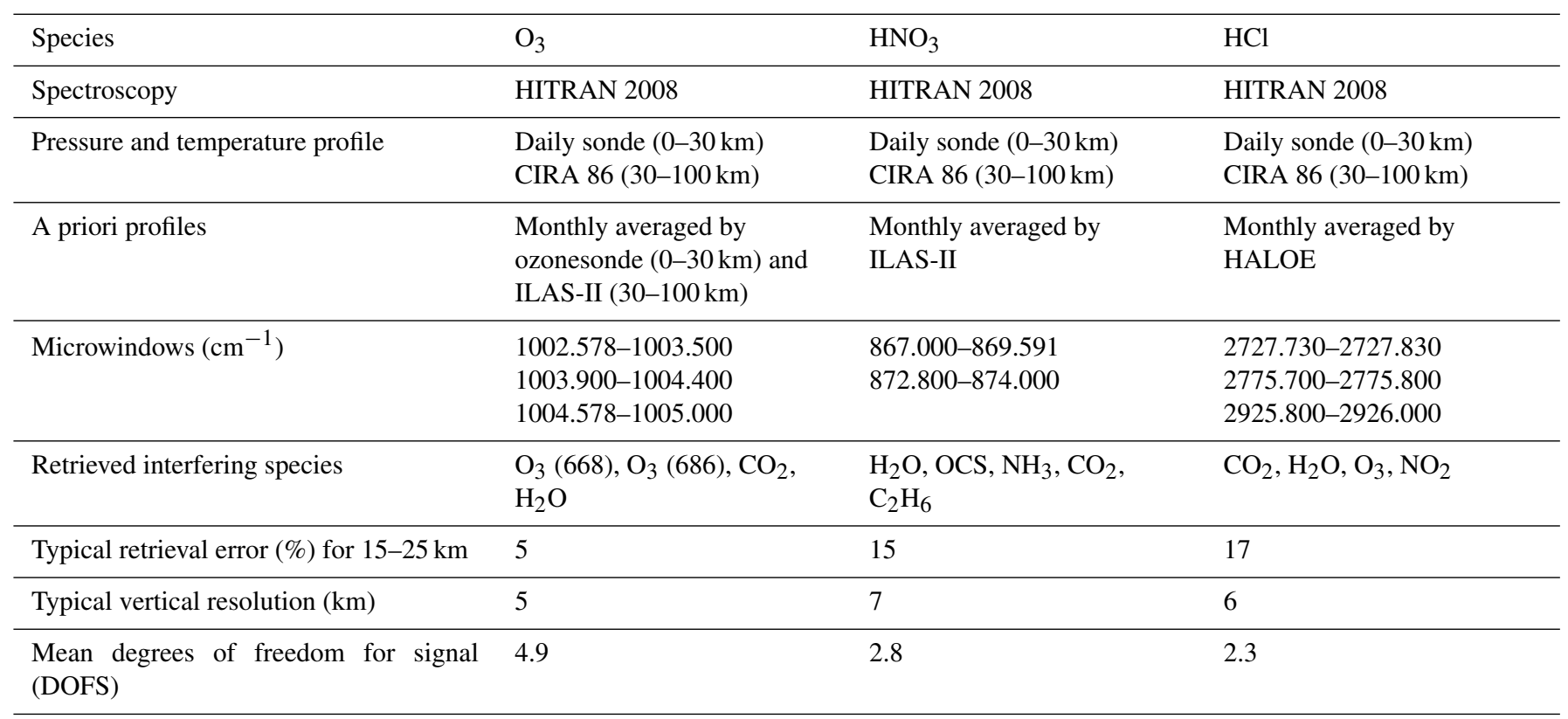
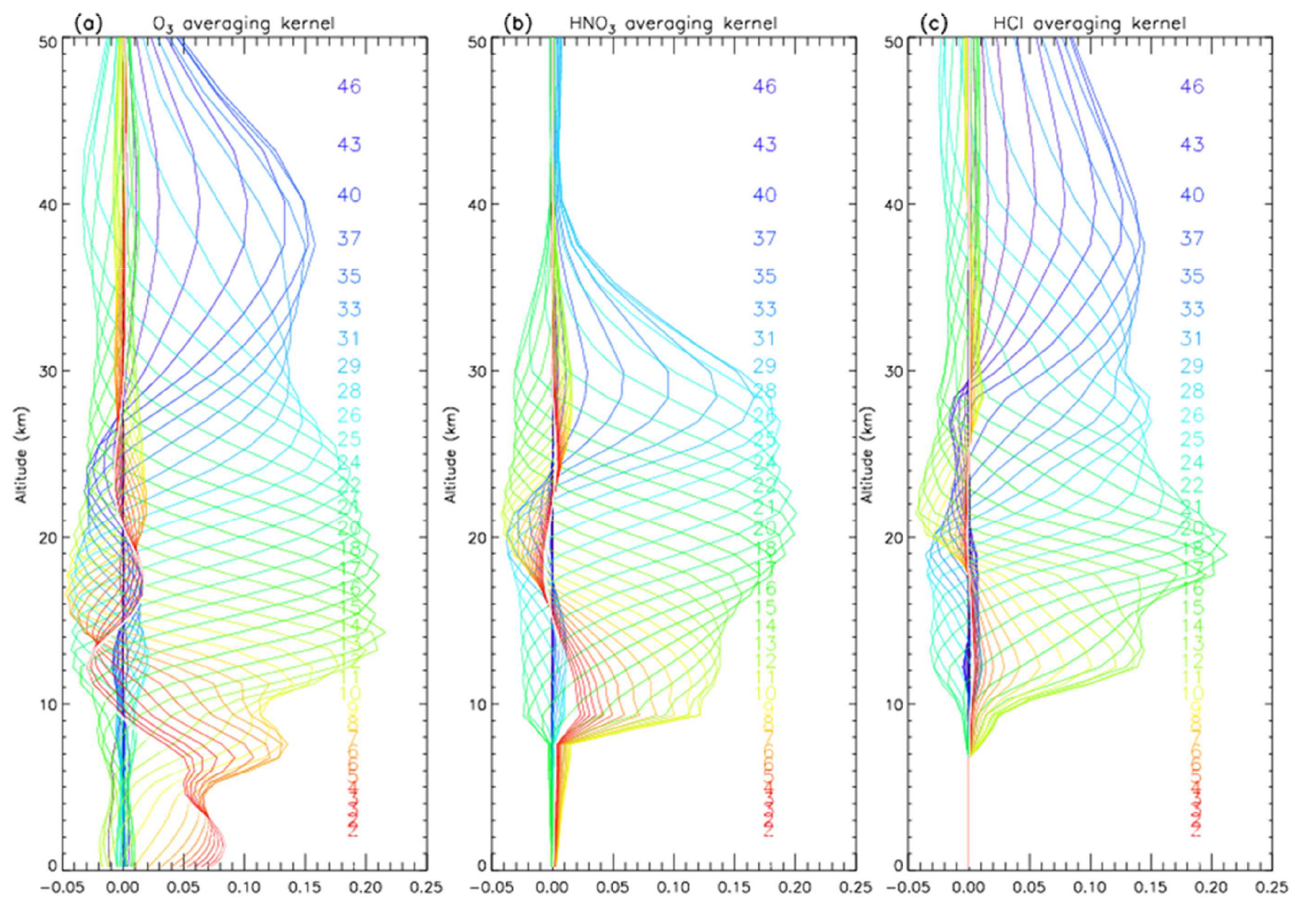

Figure 1. Averaging kernel functions of the SFIT2 retrievals for (a) $\mathrm{O}_{3}$, (b) $\mathrm{HNO}_{3}$, and (c) $\mathrm{HCl}$.

between 15 and $25 \mathrm{~km}$ was within $-10.4 \%$ to $+24.4 \%$. The average of the mean relative differences $D$ of $\mathrm{O}_{3}$ for the altitude of interest in this study $(18-22 \mathrm{~km})$ was $+6.1 \%$, with the minimum of $-10.4 \%$ and the maximum of $+19.2 \%$. FTIR data agree with validation data within root mean squares of typical errors in FTIR and validation data at the altitude of interest. Note that relatively large $D$ values be- tween 16 and $18 \mathrm{~km}$ are due to the small ozone amount in the ozone hole. Our validation results are quite comparable with the validation study at Izaña Observatory by Schneider et al. (2008).

Figure $2 \mathrm{c}-\mathrm{d}$ show absolute and relative differences of $\mathrm{O}_{3}$ profiles retrieved from FTIR measurements and those from Aura MLS measurements, respectively, calculated from 33 

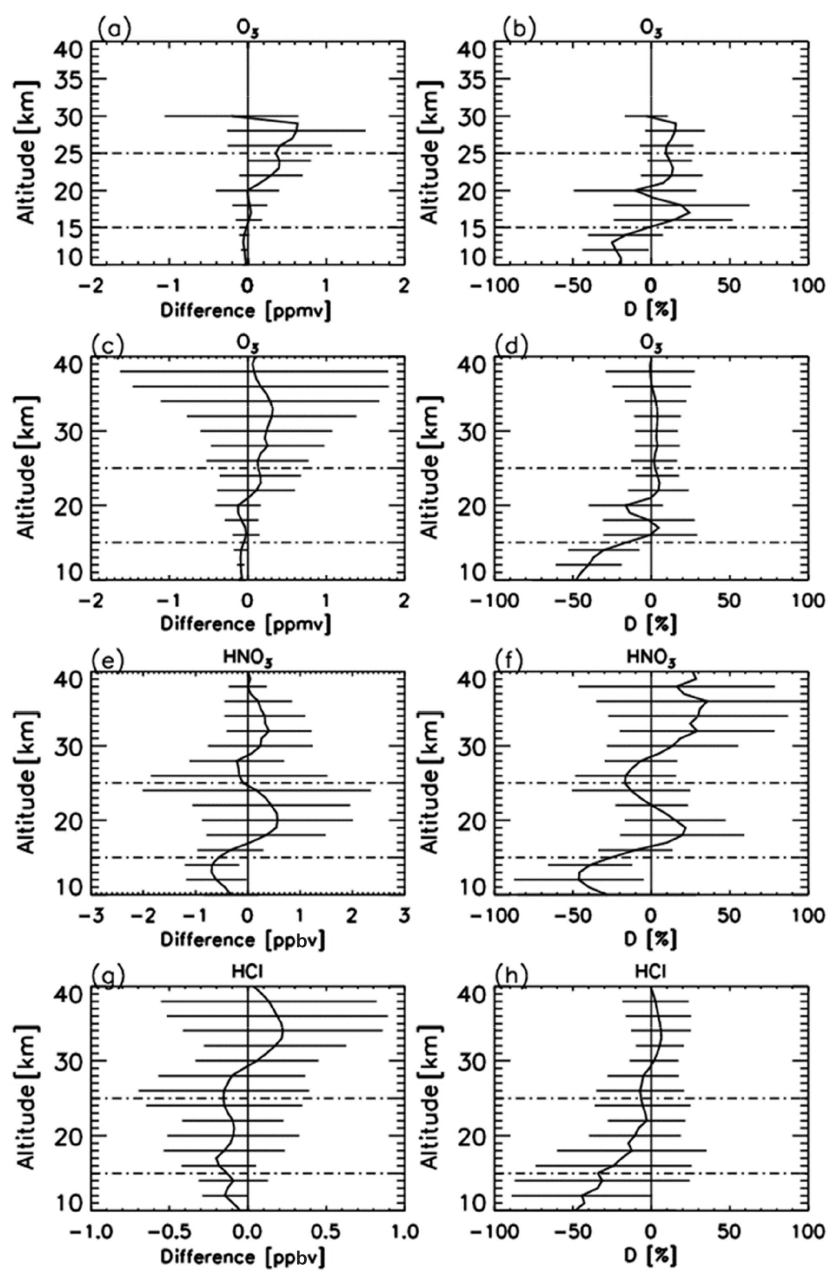

Figure 2. (a) Mean absolute and (b) mean relative differences of $\mathrm{O}_{3}$ profiles retrieved from FTIR measurements minus those from ozonesonde measurements. (c) Mean absolute and (d) mean relative differences of $\mathrm{O}_{3}$ profiles retrieved from FTIR measurements minus those from Aura MLS measurements. (e) Mean absolute and (f) mean relative differences of $\mathrm{HNO}_{3}$ profiles retrieved from FTIR measurements minus those from Aura MLS measurements. (g) Mean absolute and (h) mean relative differences of $\mathrm{HCl}$ profiles retrieved from FTIR measurements minus those from Aura MLS measurements. Horizontal bars indicate the root mean squares of differences at each altitude. Horizontal dashed bars indicate the altitude range of our focus $(15-25 \mathrm{~km})$.

coincident measurements from 1 April to 20 December 2007. The accuracy of MLS $\mathrm{O}_{3}$ data is reported to be $5 \%-8 \%$ between 0.5 and $46 \mathrm{hPa}$ (Livesey et al., 2013). The mean absolute difference between 15 and $25 \mathrm{~km}$ was within -0.13 to +0.16 ppmv. The mean relative difference $D$ between 15 and $25 \mathrm{~km}$ was within $-16.2 \%$ to $+5.2 \%$. The average of the mean relative differences $D$ for $\mathrm{O}_{3}$ for the altitude of interest in this study $(18-22 \mathrm{~km})$ was $-5.5 \%$, with the minimum of $-16.3 \%$ and the maximum of $+4.5 \%$. Froidevaux et al. (2008) showed that Aura MLS is $+8 \%$ higher than the
Atmospheric Chemistry Experiment Fourier transform spectrometer (ACE-FTS) at $70^{\circ} \mathrm{S}$, which may explain the negative bias of FTIR data compared with MLS data.

Figure 2e-f show absolute and relative differences of $\mathrm{HNO}_{3}$ profiles retrieved by FTIR measurements and those from Aura MLS measurements, respectively, calculated from 47 coincident measurements from 25 March to 20 December 2007. The mean absolute difference between 15 and $25 \mathrm{~km}$ was within -0.56 to $+0.57 \mathrm{ppbv}$. The mean relative difference $D$ between 15 and $25 \mathrm{~km}$ was within $-25.5 \%$ to $+21.9 \%$. The average of the mean relative differences $D$ for $\mathrm{HNO}_{3}$ for the altitude of interest in this study (18$22 \mathrm{~km}$ ) was $+13.2 \%$, with the minimum of $+0.2 \%$ and the maximum of $+21.9 \%$. This positive bias of FTIR data is still within the error bars of FTIR measurements. Livesey et al. (2013) showed that Aura MLS version 3.3 data have no bias within errors $(\sim 0.6-0.7 \mathrm{ppbv}(10 \%-12 \%)$ at a pressure level of 100-3.2 hPa) compared with other measurements. Livesey et al. (2018) showed no major differences between Aura MLS version 3.3 and version 4.2 data for $\mathrm{HNO}_{3}$.

Figure $2 \mathrm{~g}-\mathrm{h}$ show absolute and relative differences of $\mathrm{HCl}$ profiles retrieved by FTIR measurements and those from Aura MLS measurements, respectively, calculated from 50 coincident measurements from 25 March to 20 December 2007. The mean absolute difference between 15 and $25 \mathrm{~km}$ was within -0.20 to $-0.09 \mathrm{ppbv}$. The mean relative difference $D$ between 15 and $25 \mathrm{~km}$ was within $-34.1 \%$ to $-3.0 \%$. The average of mean relative differences $D$ for $\mathrm{HCl}$ for the altitude of interest in this study $(18-22 \mathrm{~km})$ is $-9.7 \%$, with a minimum of $-14.6 \%$ and a maximum of $-3.0 \%$. This negative bias of FTIR data is still within the error bars of FTIR measurements. Moreover, Livesey et al. (2013) showed that Aura MLS version 3.3 values are systematically greater than HALOE values by $10 \%-15 \%$ with a precision of $0.2-$ $0.6 \mathrm{ppbv}(10 \%-30 \%)$ in the stratosphere, which may partly explain the negative bias of FTIR data compared with MLS data. Livesey et al. (2018) showed no major differences between Aura MLS version 3.3 and version 4.2 data for $\mathrm{HCl}$.

Table 2 summarizes the validation results of FTIR profiles compared with ozonesonde or Aura MLS measurements, as well as possible Aura MLS biases from the literature.

\section{Results and discussion}

\subsection{Time series of observed species}

Figure 3a shows daytime hours at Syowa Station. Polar night ends at Syowa Station on 14 July (day 195). Figure 3b-e show the time series of temperatures at 18 and $22 \mathrm{~km}$ over Syowa Station using ERA-Interim data (Dee et al., 2011) for 2007 and 2011. Approximate saturation temperatures for NAT $\left(T_{\mathrm{NAT}}\right)$ and ice $\left(T_{\mathrm{ICE}}\right)$ calculated by assuming $6 \mathrm{ppbv}$ $\mathrm{HNO}_{3}$ and 4.5 ppmv $\mathrm{H}_{2} \mathrm{O}$ are also shown in the figures. The dates when PSCs were observed at Syowa Station identi- 
Table 2. Summary of validation results of FTIR profiles compared with ozonesonde and Aura MLS measurements, as well as possible Aura MLS biases from the literature.

\begin{tabular}{|c|c|c|c|c|c|c|}
\hline & $\begin{array}{r}\text { Number of } \\
\text { coincidences }\end{array}$ & $\begin{array}{r}\text { Root mean } \\
\text { squares of } \\
\text { official errors* } \\
(\%) \text { at } 18-22 \mathrm{~km}\end{array}$ & $\begin{array}{l}D(\%) \text { at } \\
18-22 \mathrm{~km}\end{array}$ & $\begin{array}{r}\operatorname{Min} / \max (\%) \\
\text { at } 18-22 \mathrm{~km}\end{array}$ & $\begin{array}{r}\text { Range of mean } \\
\text { absolute differences } \\
\text { for } 15-25 \mathrm{~km} \\
\left(\mathrm{O}_{3}: \mathrm{ppmv}\right. \\
\mathrm{HNO}_{3} \text { and } \mathrm{HCl}: \\
\text { ppbv })\end{array}$ & Literature values \\
\hline $\mathrm{O}_{3}$ (sonde) & 14 & 7.1 & +6.1 & $-10.4 /+19.2$ & -0.02 to +0.40 & \\
\hline $\mathrm{O}_{3}(\mathrm{MLS})$ & 33 & 9.4 & -5.5 & $-16.3 /+4.5$ & -0.13 to +0.16 & $\begin{array}{l}\text { Aura MLS is }+8 \% \text { higher than } \\
\text { ACE-FTS at } 70^{\circ} \mathrm{S} \text { (Froidevoux et } \\
\text { al., 2008) }\end{array}$ \\
\hline $\mathrm{HNO}_{3}$ & 47 & 19.2 & +13.2 & $+0.2 /+21.9$ & -0.56 to +0.57 & $\begin{array}{l}\text { Aura MLS shows no bias with er- } \\
\text { rors } \\
(0.6 \text { ppbv })(\text { Livesey et al., } 2013)\end{array}$ \\
\hline $\mathrm{HCl}$ & 50 & 39.5 & -9.7 & $-14.6 /-3.0$ & -0.20 to +0.09 & $\begin{array}{l}\text { Aura MLS > HALOE by } \\
10 \%-15 \% \text {, precision } 0.2-0.6 \text { ppbv } \\
\text { (Livesey et al., 2013) }\end{array}$ \\
\hline
\end{tabular}

* Root mean squares of official absolute and relative errors given by each data set.

fied by the nearest CALIOP data of that day were indicated by asterisks at the bottom of the figures. Over Syowa Station, PSCs were observed when temperature fell $\sim 4 \mathrm{~K}$ below $T_{\mathrm{NAT}}$. PSCs were often observed at $15-25 \mathrm{~km}$ from the beginning of July (day 183) to late August (day 241) in 2007 and from late June (day 175) to early September (day 251) in 2011.

PSCs were observed only at $18 \mathrm{~km}$ after August, due to the sedimentation of PSCs and downwelling of vortex air in late winter as is seen in Fig. 3. Although temperatures above Syowa Station were sometimes below $T_{\mathrm{NAT}}-4 \mathrm{~K}$ in June and in late September, no PSC was observed during those periods. This may be due to other reasons, such as a different time history of temperature for PSC formation, and/or low $\mathrm{HNO}_{3}$ (denitrification) and/or $\mathrm{H}_{2} \mathrm{O}$ concentration (dehydration), which are needed for PSC formation in the late winter season (Saitoh et al., 2006).

Figures 4-7 show time series of $\mathrm{HCl}, \mathrm{ClONO}_{2}, \mathrm{ClO}$, $\mathrm{Cl}_{y}^{*}, \mathrm{O}_{3}$, and $\mathrm{HNO}_{3}$ over Syowa Station in 2007 and 2011 at altitudes of 18 and $22 \mathrm{~km}$ for all ground-based and satellite-based observations used in this study, respectively. $\mathrm{O}_{3}$ (sonde) is observed with the KC96 ozonesonde for 2007, which is different from the ones that were used for the validation in Sect. 3 and the ECC-1Z ozonesonde for 2011 by JMA (Smit and Straeter, 2004). $\mathrm{HCl}$ and $\mathrm{HNO}_{3}$ observed by Aura MLS and FTIR are plotted by different symbols. Total inorganic chlorine $\mathrm{Cl}_{y}^{*}$ corresponds to the sum of $\mathrm{HCl}, \mathrm{ClONO}_{2}$, and $\mathrm{Cl}_{x}$, where the active chlorine species $\mathrm{Cl}_{x}$ is defined as the sum of $\mathrm{ClO}, \mathrm{Cl}$, and $2 \cdot \mathrm{Cl}_{2} \mathrm{O}_{2}$ (Bonne et al., 2000). It is known that total inorganic chlorine $\mathrm{Cl}_{y}^{*}$ has a compact relationship with $\mathrm{N}_{2} \mathrm{O}$ (Bonne et al., 2000; Schauffler et al., 2003; Strahan et al., 2014). Inferred total inorganic chlorine
$\mathrm{Cl}_{y}^{*}$ is calculated from the $\mathrm{N}_{2} \mathrm{O}$ value (in ppbv) measured by MLS and by using the empirical polynomial equation derived from the correlation analysis of $\mathrm{Cl}_{y}$ and $\mathrm{N}_{2} \mathrm{O}$ from the Photochemistry of Ozone Loss in the Arctic Region in Summer (POLARIS) mission which took place from April to September 1997 (Bonne et al., 2000). In order to compensate for the temporal trends of $\mathrm{Cl}_{y}$ and $\mathrm{N}_{2} \mathrm{O}$ values $(2.90,2.76$, and $2.67 \mathrm{ppbv}$ for $\mathrm{Cl}_{y}$ (Strahan et al., 2014) and 313, 321, and 324 ppbv for $\mathrm{N}_{2} \mathrm{O}$ (WMO, 2007, 2011, 2014) for the years 1997, 2007, and 2011, respectively), we used values 8 and 11 for constant $A$ and 140 and 230 for constant $B$ for years 2007 and 2011 in the following equation, respectively:

$$
\begin{aligned}
\mathrm{Cl}_{y}^{*}(\mathrm{pptv}) & =4.7070 \times 10^{-7}\left(\mathrm{~N}_{2} \mathrm{O}-A\right)^{4} \\
& -3.2708 \times 10^{-4}\left(\mathrm{~N}_{2} \mathrm{O}-A\right)^{3} \\
& +4.0818 \times 10^{-2}\left(\mathrm{~N}_{2} \mathrm{O}-A\right)^{2} \\
& -4.6856\left(\mathrm{~N}_{2} \mathrm{O}-A\right)+3225-B .
\end{aligned}
$$

A transport barrier of minor constituents at the edge of the polar vortex was reported by Lee et al. (2001) and Tilmes et al. (2006). The distribution of minor constituents is quite different among the inside, in the boundary region, and outside of the polar vortex. In Figs. 4-7, the dark shaded area, the light shaded area, and the white area indicate the days when Syowa Station was located outside, in the boundary region, and inside of the polar vortex, respectively. In the Antarctic winter, there are often double peaks in the isentropic potential vorticity (PV) gradient with respect to equivalent latitude at the 450-600 K level (Tomikawa et al., 2015). The method to determine the three polar regions, i.e., inside the polar vortex, in the boundary region of the polar vortex, and outside the polar vortex, is described in Appendix B. Note that the 

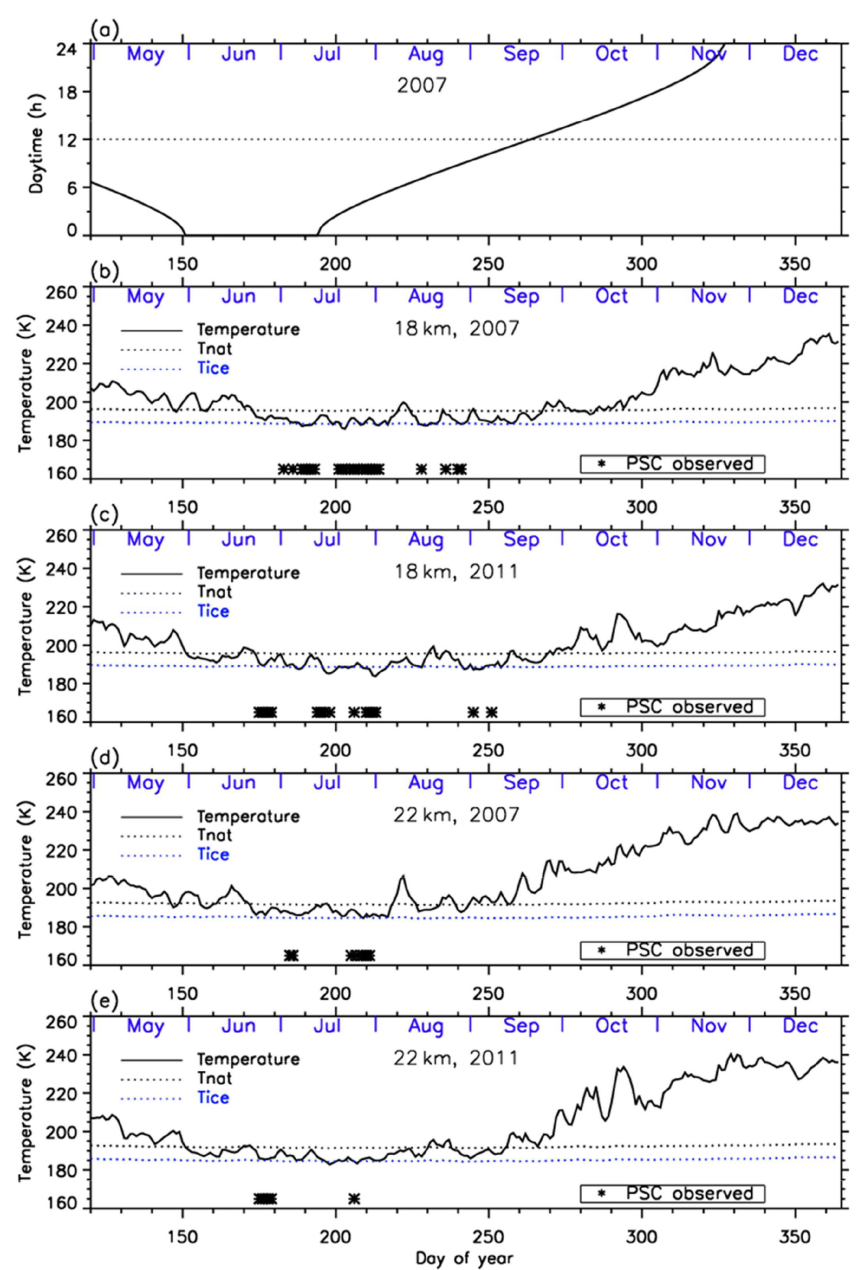

Figure 3. Time series of (a) daytime hour and temperatures at $18 \mathrm{~km}$ in (b) 2007 and (c) 2011 and at $22 \mathrm{~km}$ in (d) 2007 and (e) 2011 over Syowa Station using ERA-Interim data. Approximate saturation temperatures for nitric acid trihydrate $\left(T_{\mathrm{NAT}}\right)$ and ice $\left(T_{\mathrm{ICE}}\right)$ calculated by assuming 6 ppbv $\mathrm{HNO}_{3}$ and 4.5 ppmv $\mathrm{H}_{2} \mathrm{O}$ are also plotted in the figures by dotted lines. Dates when PSCs were observed over Syowa Station are indicated by asterisks on the bottom of the figures.

Syowa Station is often located near the vortex edge, and the temporal variations of chemical species observed over Syowa Station reflect the spatial distributions as well as local chemical evolution. When Syowa Station was located at the boundary region or outside the polar vortex (e.g., day 310-316 in Fig. 4, day 192-195 in Fig. 5, day 309-316 in Fig. 6, and day 276-282 in Fig. 7), chemical species showed different values compared with the ones inside the polar vortex. The lack of data for $\mathrm{ClO}$ and $\mathrm{HCl}$ (MLS) from day 195 to day 219, 2007, and $\mathrm{ClONO}_{2}$ from day 170 to day 216, 2007 (Figs. 4a and 6a), is due to unrealistic large error values in Aura MLS or Envisat MIPAS data products during these periods.

The altitude of $18 \mathrm{~km}$ was selected because it was one of the altitudes where nearly complete ozone loss occurred. The altitude of $22 \mathrm{~km}$, where only about half of the ozone was depleted, was selected to show the difference in the behavior of chemical species from that at $18 \mathrm{~km}$.

The general features of the chemical species observed inside the polar vortex at 18 and $22 \mathrm{~km}$ in 2007 and 2011 are summarized as follows: $\mathrm{HCl}$ and $\mathrm{ClONO}_{2}$ decreased first, and then $\mathrm{ClO}$ started to increase in winter, while $\mathrm{HCl}$ increases and $\mathrm{ClO}$ decreases were synchronized in spring. $\mathrm{HCl}$ was almost zero from late June to early September, and the day-to-day variations were small over this period. $\mathrm{HCl}$ over Syowa Station indicates relatively larger values when it was located outside the polar vortex: for example, early August and the beginning of September at $22 \mathrm{~km}, 2007$, in Fig. 6. $\mathrm{HNO}_{3}$ showed large decreases from June to July and then gradually increased in summer. Day-to-day variations of $\mathrm{HNO}_{3}$ from June to August were large. $\mathrm{O}_{3}$ decreased from July to late September when $\mathrm{ClO}$ concentration was increased. $\mathrm{ClO}$ was enhanced in August and September, and the day-to-day variations were large over this period. $\mathrm{Cl}_{y}^{*}$ gradually increased in the polar vortex from late autumn to spring. The $\mathrm{Cl}_{y}^{*}$ value became larger compared with its mixing ratio outside of the polar vortex in spring.

The following characteristics are evident at $18 \mathrm{~km}$ (Figs. 4 and 5). $\mathrm{O}_{3}$ gradually decreased from values of $2.5-3 \mathrm{ppmv}$ before winter to values less than one-fifth, $0.3-0.5 \mathrm{ppmv}$, in October. The values of $\mathrm{HCl}$ from late June to early September were as small as $0-0.3 \mathrm{ppbv}$. The recovered values of $\mathrm{HCl}$ inside the vortex in spring (October-December) were larger than those before winter and those outside the polar vortex during the same period. $\mathrm{ClONO}_{2}$ inside the vortex kept near zero even after $\mathrm{ClO}$ disappeared and did not recover to the level before winter until spring.

At $22 \mathrm{~km}$ (Figs. 6 and 7), $\mathrm{O}_{3}$ gradually decreased from winter to spring, but the magnitude of the decrease was much smaller than that at $18 \mathrm{~km}$. The values of $\mathrm{HCl}$ from late June to early September were $0-1 \mathrm{ppbv}$, which are larger than those at $18 \mathrm{~km}$. The recovered values of $\mathrm{HCl}$ in spring were nearly the same as those before winter (around $2.2 \mathrm{ppbv}$ ). $\mathrm{ClONO}_{2}$ recovered to larger values than those before winter after $\mathrm{ClO}$ disappeared.

As for the temporal increase in $\mathrm{ClONO}_{2}$ in spring during the $\mathrm{ClO}$ decreasing phase, we can see a peak of $1.5 \mathrm{ppbv}$ at $18 \mathrm{~km}$ in 2011 and at $22 \mathrm{~km}$ in both 2007 and 2011 around 27 September (day 270), but we see no temporal increase in $\mathrm{ClONO}_{2}$ at $18 \mathrm{~km}$ in 2007.

Figure 7 shows that temporal $\mathrm{ClO}$ enhancement and decrease in $\mathrm{O}_{3}, \mathrm{ClONO}_{2}$, and $\mathrm{HNO}_{3}$ occurred in early winter (30 May-19 June; day 150-170) at $22 \mathrm{~km}$ in 2011. This small ozone depletion event before winter may be due to an air mass movement from the polar night area to a sunlit area at lower latitudes. 


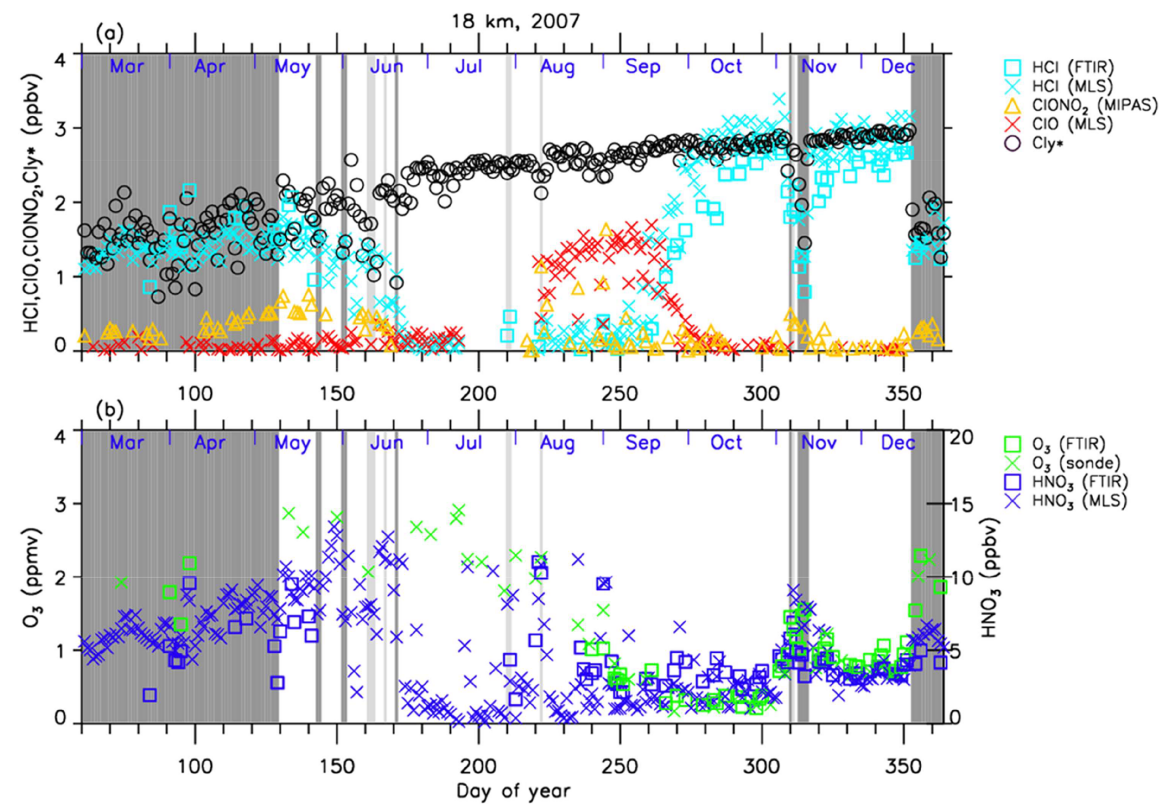

Figure 4. Time series of (a) $\mathrm{HCl}, \mathrm{ClONO}_{2}, \mathrm{ClO}$, and $\mathrm{Cl}_{y}^{*}$ as well as (b) $\mathrm{O}_{3}$ and and $\mathrm{HNO}_{3}$ mixing ratios at $18 \mathrm{~km}$ in 2007 over Syowa Station. $\mathrm{O}_{3}$ (FTIR), $\mathrm{HCl}$ (FTIR), and $\mathrm{HNO}_{3}$ (FTIR) were measured by FTIR at Syowa Station, while $\mathrm{HCl}(\mathrm{MLS}), \mathrm{ClO}(\mathrm{MLS})$, and $\mathrm{HNO}$ (MLS) were measured by Aura MLS. $\mathrm{O}_{3}$ (sonde) was measured by ozonesonde. $\mathrm{ClONO}_{2}$ was measured by Envisat MIPAS. Cl* is calculated from the Aura MLS $\mathrm{N}_{2} \mathrm{O}$ value. See text in detail. The unit of $\mathrm{O}_{3}$ is parts per million by volume (ppmv) and the other gases are parts per billion by volume (ppbv). The dark shaded area, the light shaded area, and the white area indicate the days when Syowa Station was located outside the polar vortex, in the boundary region of the polar vortex, and inside the polar vortex, respectively.

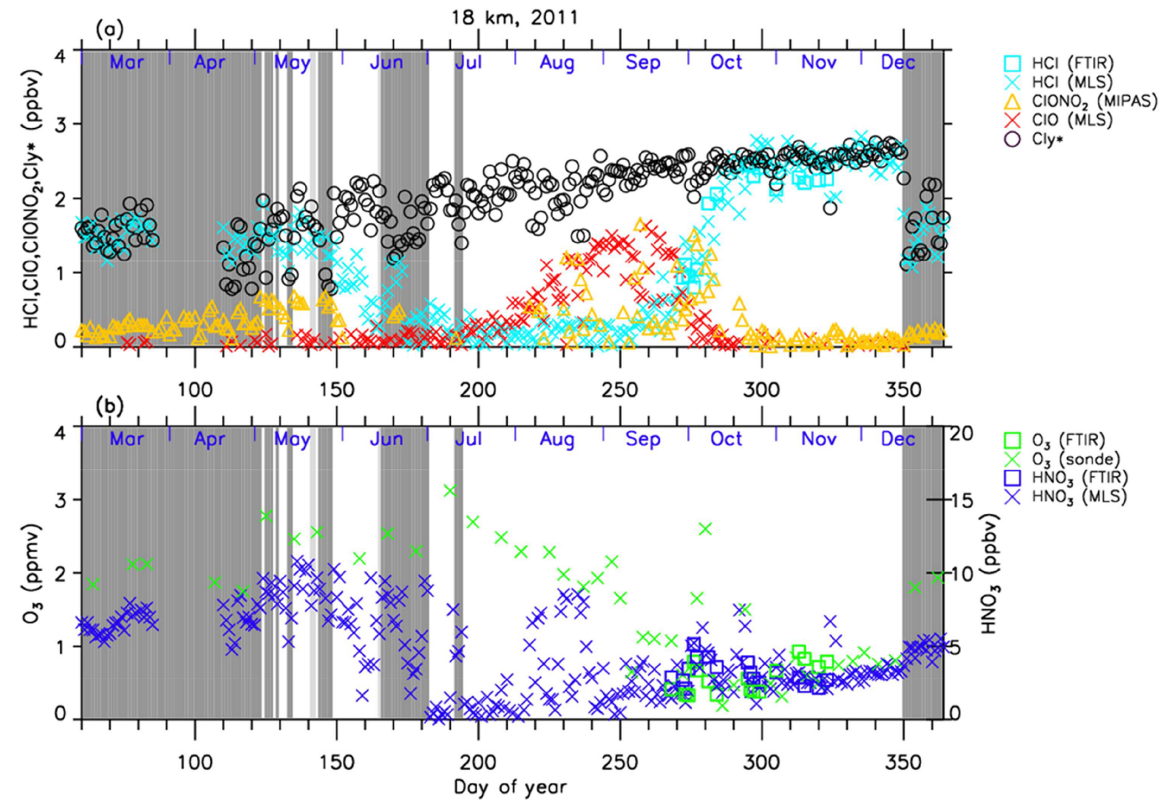

Figure 5. Same as Fig. 4 but in 2011.

\subsection{Time series of ratios of chlorine species}

In order to discuss the temporal variations of the chlorine partitioning, the ratios of observed $\mathrm{HCl}, \mathrm{ClONO}_{2}$, and $\mathrm{ClO}$ with respect to $\mathrm{Cl}_{y}^{*}$ were calculated. Hereafter, we will dis- cuss the ratios of chlorine species only for the cases when Syowa Station was located inside the polar vortex.

Figures 8 and 9 show the time series of the ratios of each chlorine species with respect to $\mathrm{Cl}_{y}^{*}$ in 2007 (a) and in 2011 (b) at 18 and $22 \mathrm{~km}$, respectively. In these plots, $\mathrm{HCl}$ 


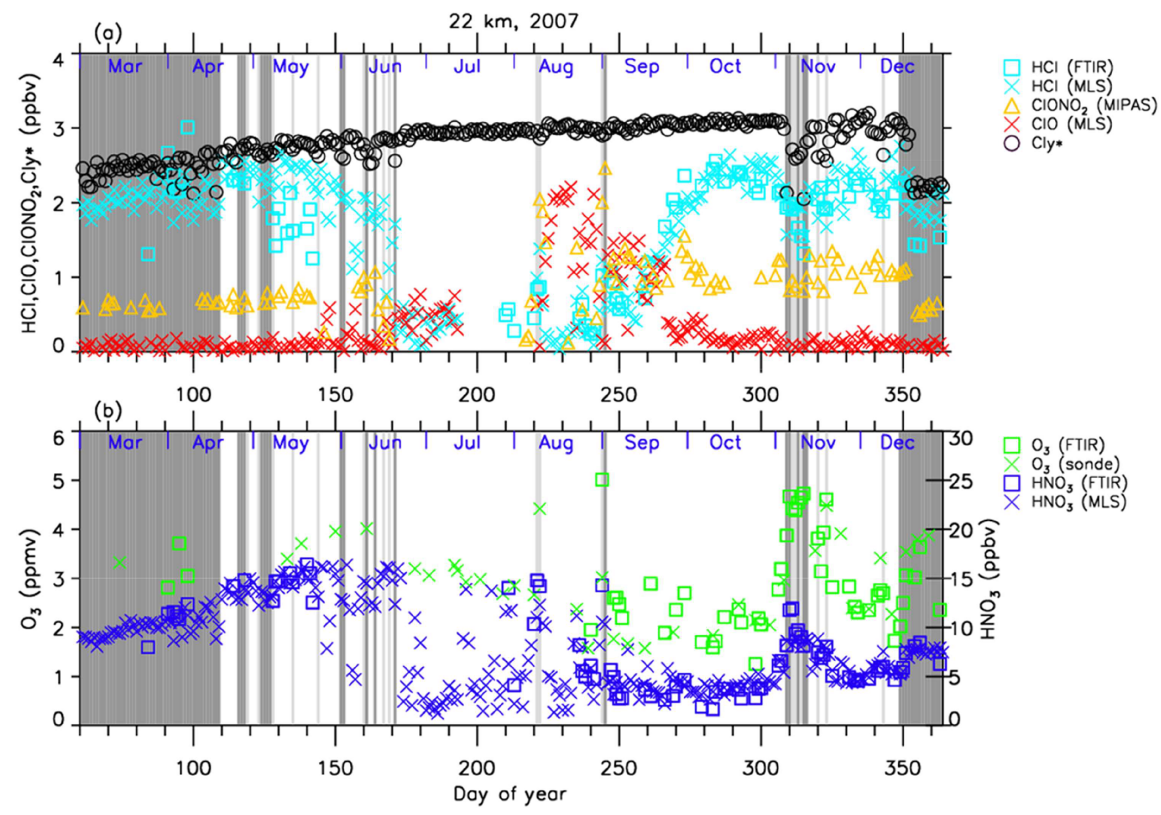

Figure 6. Same as Fig. 4 but at $22 \mathrm{~km}$.

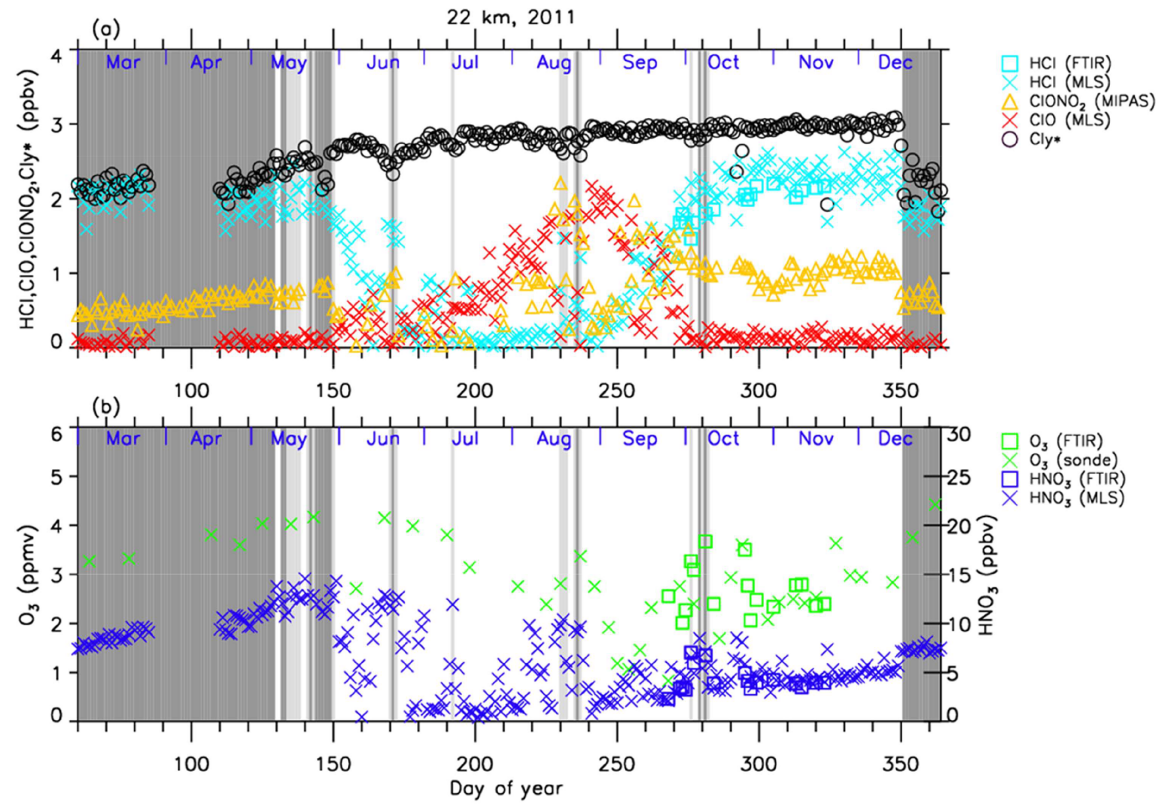

Figure 7. Same as Fig. 5 but at $22 \mathrm{~km}$.

data from Aura MLS were used. Note that light blue in these figures shows that either $\mathrm{ClONO}_{2}$ or $\mathrm{ClO}$ data were missing on that day, while dark blue shows that all three data sets were available on that day. For both 2007 and 2011 at $18 \mathrm{~km}$ (Fig. 8), $\mathrm{HCl} / \mathrm{Cl}_{y}^{*}$ was $0.6-0.8$ and $\mathrm{ClONO}_{2} / \mathrm{Cl}_{y}^{*}$ was $0.2-0.3$ before winter (10-20 May; day 130-140). The ratio of $\mathrm{HCl}$ to $\mathrm{Cl}_{y}^{*}$ was 3 times larger than that of $\mathrm{ClONO}_{2}$ at that time. $\mathrm{ClO} / \mathrm{Cl}_{y}^{*}$ increased to $\sim 0.5$ during the $\mathrm{ClO}$ enhanced period (the period when $\mathrm{ClO}$ values were more than $80 \%$ of its maximum value: 18 August-17 September; day $230-260) . \mathrm{HCl} / \mathrm{Cl}_{y}^{*}$ was $0-0.2$ and $\mathrm{ClONO}_{2} / \mathrm{Cl}_{y}^{*}$ was $0-0.6$ during this same period. $\mathrm{ClONO}_{2}$ shows a negative correlation with $\mathrm{ClO}$, while $\mathrm{HCl}$ remained low even when $\mathrm{ClO}$ was low during this period. This negative correlation is shown in Fig. 10. When $\mathrm{ClO}$ was enhanced, the $\mathrm{O}_{3}$ amount gradually decreased and finally reached $<0.5 \mathrm{ppmv}$ (> $80 \%$ destruction) in October (7 October; day 280) (see Figs. 4 and 5). The ratios to $\mathrm{Cl}_{y}^{*}$ became $0.9-1.0$ for $\mathrm{HCl}$ and 
$0-0.1$ for $\mathrm{ClONO}_{2}$ after the recovery in spring (after 17 October; day 290), indicating that almost all chlorine reservoir species became $\mathrm{HCl}$ via Reactions (R13) and/or (R14), due to the lack of $\mathrm{O}_{3}$ and $\mathrm{NO}_{2}$ during this period. The sum ratios $\left(\mathrm{HCl}+\mathrm{ClONO}_{2}+\mathrm{ClO}\right) / \mathrm{Cl}_{y}^{*}$ were around $0.5-0.8$ at the time of the $\mathrm{ClO}$-enhanced period. The remaining chlorine is thought to be either $\mathrm{Cl}_{2} \mathrm{O}_{2}$ or $\mathrm{HOCl}$, which will be shown in model simulation result in Sect. 4.6. The sum ratio $\left(\mathrm{HCl}+\mathrm{ClONO}_{2}\right) / \mathrm{Cl}_{y}^{*}$ became close to 1 after the recovery period (after 7 October; day 280).

For both 2007 and 2011 at $22 \mathrm{~km}$ (Fig. 9), $\mathrm{HCl} / \mathrm{Cl}_{y}^{*}$ was $0.8-0.9$ and $\mathrm{ClONO}_{2} / \mathrm{Cl}_{y}^{*}$ was $0.2-0.3$ before winter (20 April-20 May; day 110-140). The ratio of $\mathrm{HCl}$ to $\mathrm{Cl}_{y}^{*}$ was 3 to 4 times larger than that of $\mathrm{ClONO}_{2} \cdot \mathrm{ClO} / \mathrm{Cl}_{y}^{*}$ increased to $0.5-0.7$ during the $\mathrm{ClO}$-enhanced period (828 August - day 220-240 in 2007; 18 August-7 September day 230-250 in 2011). $\mathrm{HCl} / \mathrm{Cl}_{y}^{*}$ was $0-0.2$ and $\mathrm{ClONO}_{2} / \mathrm{Cl}_{y}^{*}$ was $0-0.6$ during this period. $\mathrm{ClONO}_{2}$ shows a negative correlation with $\mathrm{ClO}$, while $\mathrm{HCl}$ remained low even when $\mathrm{ClO}$ was low during this period as in the case at $18 \mathrm{~km}$. The $\mathrm{O}_{3}$ amount gradually decreased during the $\mathrm{ClO}$-enhanced period but the concentration remained at more than $1.5 \mathrm{ppmv}$ (less than half destruction) at this altitude (see Figs. 6 and 7). When the $\mathrm{ClO}$ enhancement ended, the increase in both $\mathrm{ClONO}_{2}$ and $\mathrm{HCl}$ occurred simultaneously in early spring (17 September-7 October; day 260-280). Then the ratios to $\mathrm{Cl}_{y}^{*}$ became $0.6-0.7$ for $\mathrm{HCl}$ and $0.3-0.4$ for $\mathrm{ClONO}_{2}$ in spring (after 7 October; day 280). This phenomenon shows that more chlorine deactivation via Reaction (R12) occurred towards $\mathrm{ClONO}_{2}$ at $22 \mathrm{~km}$ rather than at $18 \mathrm{~km}$. This is attributed to the existence of $\mathrm{O}_{3}$ and $\mathrm{NO}_{2}$ during this period at $22 \mathrm{~km}$, which was different from the case at $18 \mathrm{~km}$. The sum ratios $\left(\mathrm{HCl}+\mathrm{ClONO}_{2}+\mathrm{ClO}\right) / \mathrm{Cl}_{y}^{*}$ were around $0.7-$ 1.2 at the time of the $\mathrm{ClO}$-enhanced period. The remaining chlorine is thought to be either $\mathrm{Cl}_{2} \mathrm{O}_{2}$ or $\mathrm{HOCl}$. The sum ratio $\left(\mathrm{HCl}+\mathrm{ClONO}_{2}+\mathrm{ClO}\right) / \mathrm{Cl}_{y}^{*}$ became around 1.2 after the recovery period (after 27 September; day 270). The reason why the observed sum ratio exceeds the calculated $\mathrm{Cl}_{y}^{*}$ value might be because the $\mathrm{N}_{2} \mathrm{O}-\mathrm{Cl}_{y}$ correlation from the one in Eq. (2) is not applicable at this altitude.

In 2011 at $18 \mathrm{~km}$ (Fig. 8), another temporal increase in $\mathrm{ClONO}_{2}$ up to a ratio of 0.4 occurred in early spring (around 2-12 October; day 275-285) in accordance with the $\mathrm{HCl}$ increase, and then the $\mathrm{ClONO}_{2}$ amount gradually decreased to nearly zero after late October (after 27 October; day 300). This temporal increase in $\mathrm{ClONO}_{2}$ could be attributed to the temporal change of the location of Syowa Station with respect to the polar vortex. Although Syowa Station was judged to be inside the polar vortex during 14 July-16 December (day 195-350) by our analysis, the difference between the equivalent latitude over Syowa Station and that at the inner edge became less than $10^{\circ}$ on around 7 October (day 280), while it was typically between 15 and $20^{\circ}$ on other days. $\mathrm{O}_{3}$ and $\mathrm{HNO}_{3}$ showed higher values around 7 October (day 280) (see Fig. 5), indicating that Syowa Station was located close to the boundary region during this period (see Fig. B2 in Appendix $\mathrm{B}$ ). Therefore, the temporal increase in $\mathrm{ClONO}_{2}$ in 2011 at $18 \mathrm{~km}$ was attributed to spatial variation, not to chemical evolution.

\subsection{Correlation between $\mathrm{ClO}$ and $\mathrm{ClONO}_{2}$}

Figure 10 shows the correlation between $\mathrm{ClO}$ and $\mathrm{ClONO}_{2}$ during the $\mathrm{ClO}$-enhanced period ( 8 August-17 September; day 220-260) at $18 \mathrm{~km}$ in 2007 (a) and 2011 (b) and at $22 \mathrm{~km}$ in 2007 (c) and 2011 (d). In this plot, the location of Syowa Station with respect to the polar vortex (inside, in the boundary region, and outside of the polar vortex) is indicated by different symbols. Note that MLS $\mathrm{ClO}$ and MIPAS $\mathrm{ClONO}_{2}$ data were sampled on the same day at the nearest orbit to Syowa Station for both satellites. The maximum differences between these two satellites' observational times and locations are $9.0 \mathrm{~h}$ in time and $587 \mathrm{~km}$ in distance. Mean differences are $6.8 \mathrm{~h}$ in time and $270 \mathrm{~km}$ in distance, respectively. Solid lines show regression lines obtained by reduced major axis (RMA) regression. Negative correlations of slope of about -1.0 between $\mathrm{ClO}$ and $\mathrm{ClONO}_{2}$ are seen in all figures.

The negative correlation between $\mathrm{ClO}$ and $\mathrm{ClONO}_{2}$ at Syowa Station is explained by the difference in the concentration of $\mathrm{ClO}, \mathrm{NO}_{2}, \mathrm{ClONO}_{2}$, and $\mathrm{HNO}_{3}$ inside, outside, and at the boundary region of the polar vortex around the station. Outside of the polar vortex, the $\mathrm{ClO}$ concentration is lower and $\mathrm{NO}_{2}$ concentration is higher than those inside the polar vortex. Inside the polar vortex, $\mathrm{HNO}_{3}$ is taken up by PSCs and removed by the sedimentation of PSCs from the lower stratosphere (denitrification process). The $\mathrm{NO}_{x}$ concentration is low because $\mathrm{HNO}_{3}$ is a reservoir of $\mathrm{NO}_{x}$ through the reactions

$\mathrm{NO}_{2}+\mathrm{OH}+M \rightarrow \mathrm{HNO}_{3}+M$,

$\mathrm{HNO}_{3}+h v \rightarrow \mathrm{NO}_{2}+\mathrm{OH}$,

and

$\mathrm{HNO}_{3}+\mathrm{OH} \rightarrow \mathrm{NO}_{3}+\mathrm{H}_{2} \mathrm{O}$.

The $\mathrm{NO}_{2}$ concentration is low and $\mathrm{ClONO}_{2}$ concentration is also low due to the consumption of $\mathrm{ClONO}_{2}$ by the heterogeneous Reaction (R2) inside the polar vortex. In spring, the $\mathrm{ClO}$ amount increases due to the activation of chlorine species by Reactions (R1)-(R8) inside the polar vortex. At the boundary region, $\mathrm{ClO}$ and $\mathrm{NO}_{2}$ concentrations indicate the value between the inside and outside of the polar vortex; that is, the $\mathrm{ClO}$ concentration is much higher than that outside of the polar vortex and $\mathrm{NO}_{2}$ concentration is much higher than that inside of the polar vortex. Thus, the $\mathrm{ClONO}_{2}$ concentration there is elevated in August-September due to Reaction (R12). This causes the negative correlation between $\mathrm{ClO}$ and $\mathrm{ClONO}_{2}$ due to the relative distance between Syowa Station and the edge of the polar vortex. When Syowa Station was located deep inside the polar vortex, there was more 


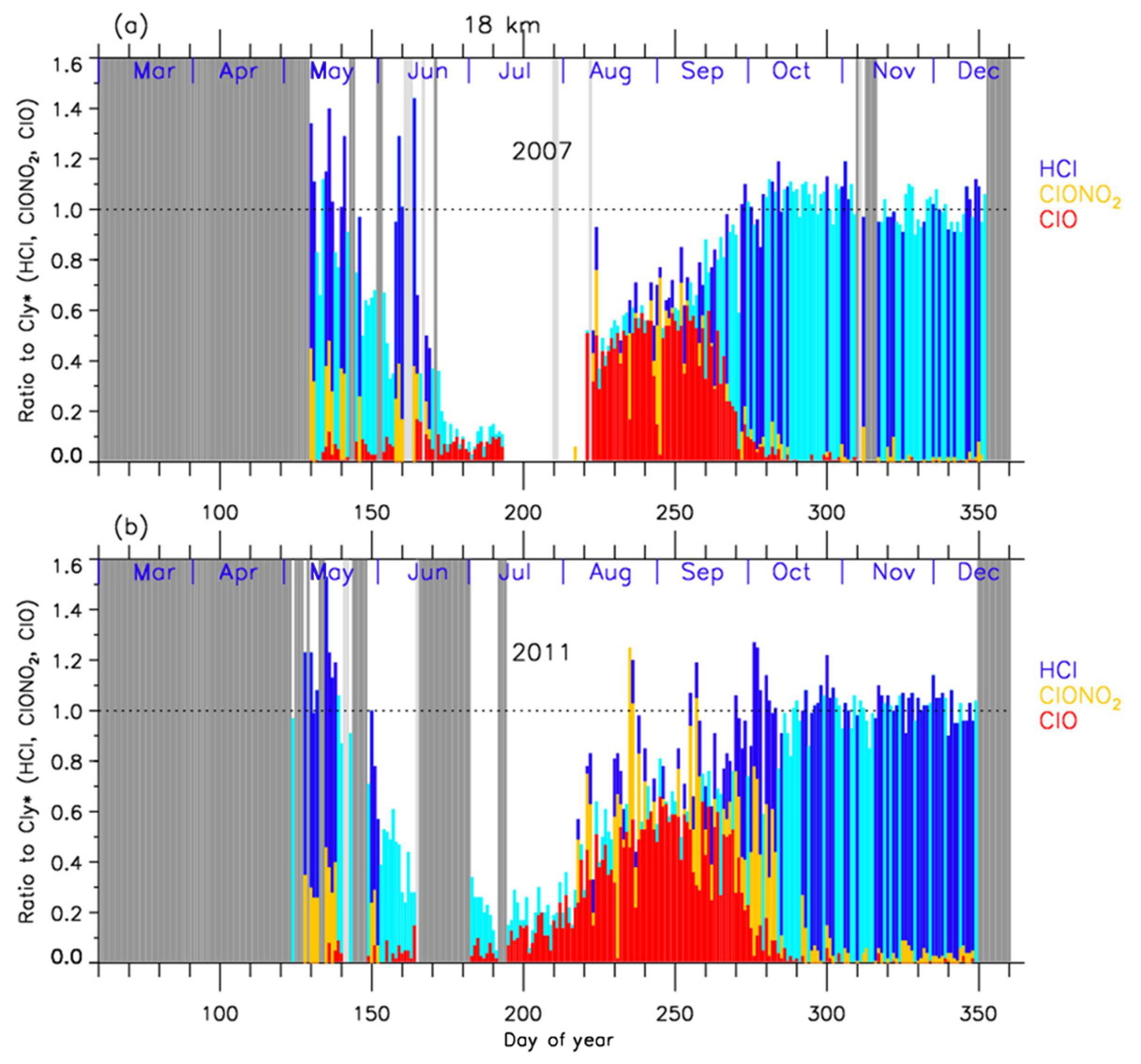

Figure 8. Time series of the ratios of $\mathrm{HCl}$ (dark blue or light blue), $\mathrm{ClONO}_{2}$ (yellow), and $\mathrm{ClO}$ (red) to total chlorine ( $\mathrm{Cl}_{y}^{*}$ ) over Syowa Station at $18 \mathrm{~km}$ in (a) 2007 and in (b) 2011. Light blue shows that either $\mathrm{ClONO}_{2}$ or $\mathrm{ClO}$ data were missing on that day, while dark blue shows that all three data sets were available on that day. Shaded areas are the same as Fig. 4.

$\mathrm{ClO}$ and less $\mathrm{ClONO}_{2}$. On the contrary, when Syowa Station was located near the vortex edge, there was less $\mathrm{ClO}$ and more $\mathrm{ClONO}_{2}$. The equivalent latitude (EL) over Syowa Station was calculated as described in Appendix B for each correlation point. The EL at each correlation point is now shown by the color code in Fig. 10. It generally shows the tendency that warm-colored higher equivalent latitude points are located more towards the bottom right-hand side. This is further confirmed by three-dimensional model simulation as shown later.

\subsection{Comparison with model results}

Figures 11 and 12 show comparisons of daily time series of simulated mixing ratios of $\mathrm{ClO}, \mathrm{HCl}, \mathrm{ClONO}_{2}, \mathrm{Cl}_{y}$, and $\mathrm{O}_{3}$ by the MIROC3.2 chemistry-climate model (Akiyoshi et al., 2016) with FTIR, Aura MLS, and Envisat MIPAS measurements at 18 and $22 \mathrm{~km}$. For a description of the MIROC3.2 CCM, please see Appendix A. In these figures, $\mathrm{Cl}_{y}$ for Aura MLS in the panels (d) and (i) actually represents the $\mathrm{Cl}_{y}^{*}$ value calculated by Eq. (2) using the $\mathrm{N}_{2} \mathrm{O}$ value measured by Aura MLS. $\mathrm{Cl}_{y}$ from the MIROC3.2 CCM is the sum of total reactive chlorines; i.e., $\mathrm{Cl}_{y}=\mathrm{Cl}+2 \cdot \mathrm{Cl}_{2}+\mathrm{ClO}+2 \cdot \mathrm{Cl}_{2} \mathrm{O}_{2}+$ $\mathrm{OClO}+\mathrm{HCl}+\mathrm{HOCl}+\mathrm{ClONO}{ }_{2}+\mathrm{ClNO}_{2}+\mathrm{BrCl}$. Note that we plotted modeled values at 12:00 UTC $(\sim$ 15:00 local time of Syowa Station) calculated by the MIROC3.2 CCM in order to compare the daytime measurements of FTIR and satellites. In Fig. $11 \mathrm{~b}, \mathrm{~d}, \mathrm{~g}$, and $\mathrm{i}$, modeled $\mathrm{HCl}$ and $\mathrm{Cl}_{y}$ are systematically smaller by $20 \%-40 \%$ compared with FTIR or MLS measurements. The cause of this discrepancy may be partly due to either smaller downward advection and/or faster horizontal mixing of an air mass across the subtropical barrier in MIROC3.2 CCM (Akiyoshi et al., 2016). Nevertheless, evolutions of measured $\mathrm{ClO}$ and $\mathrm{ClONO}_{2}$ for the period are well simulated by the MIROC3.2 CCM. Modeled $\mathrm{O}_{3}$ were in very good agreement with FTIR and/or MLS measurements throughout the year in both altitudes for both years. Hereafter, the result of MIROC3.2 CCM at $50 \mathrm{hPa}(\sim 18 \mathrm{~km})$ is discussed.

\subsection{Polar distribution of minor species}

Figure 13 shows distributions of temperature from the model nudged toward the ERA-Interim data and simulated mix- 


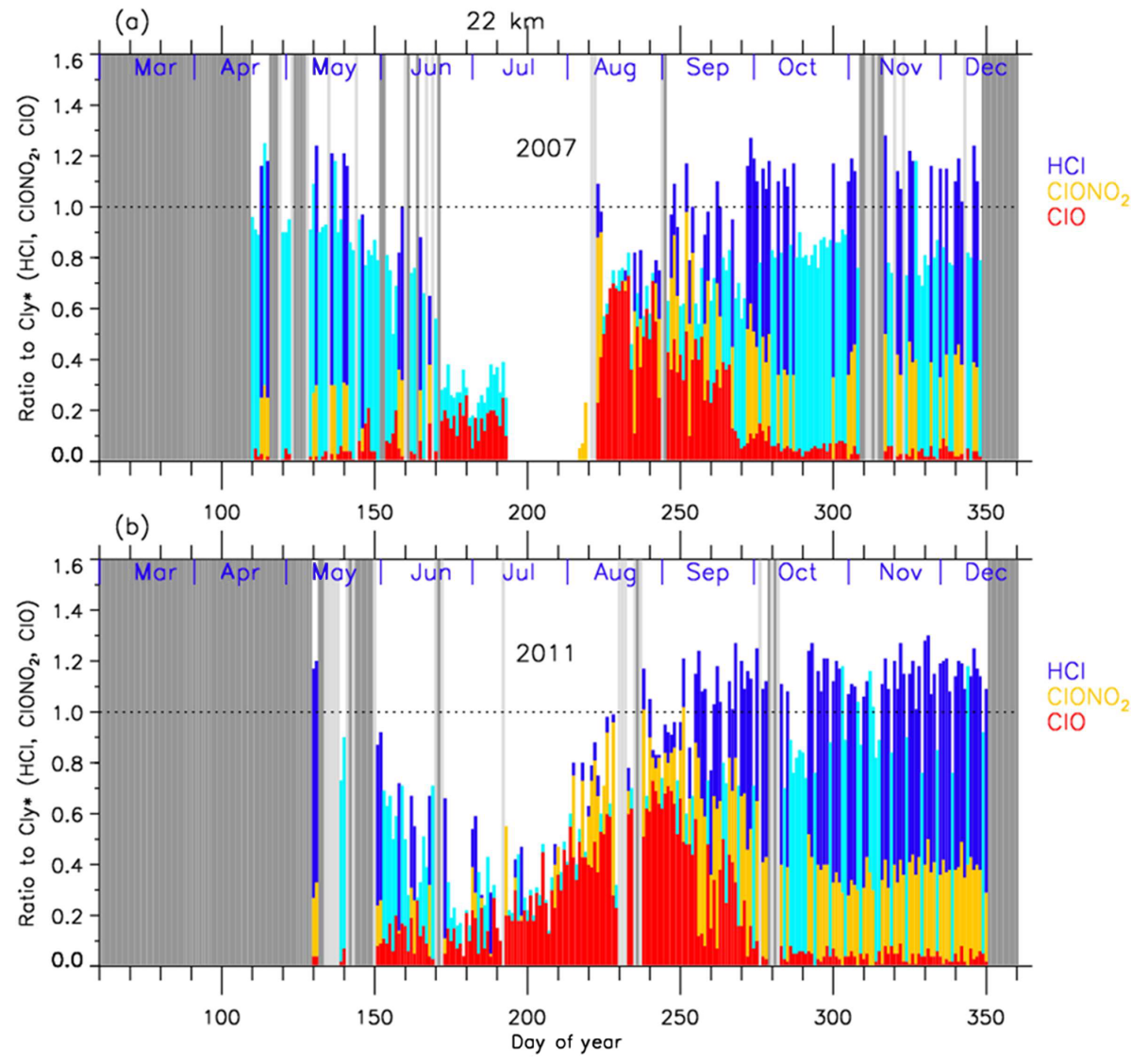

Figure 9. Same as Fig. 8 but at $22 \mathrm{~km}$.

ing ratios of $\mathrm{O}_{3}, \mathrm{NO}_{2}, \mathrm{HNO}_{3}, \mathrm{ClO}, \mathrm{HCl}$, and $\mathrm{ClONO}_{2}$ by the MIROC3.2 CCM at $50 \mathrm{hPa}$ for 24 June (day 175), 2 September (day 245), 6 September (day 249), and 6 October (day 279) in 2007. Polar vortex edges defined by the method described in Appendix B were plotted with white outlines. The location of Syowa Station is shown by a white star in each panel. On 24 June (day 175), stratospheric temperatures over Antarctica were already low enough for the onset of heterogeneous chemistry. Consequently, $\mathrm{NO}_{2}$ was converted into $\mathrm{HNO}_{3}$ via Reaction (R17), and $\mathrm{HNO}_{3}$ in the polar vortex was condensed onto PSCs. Note that the depleted area of $\mathrm{NO}_{2}$ was greater than that of $\mathrm{HNO}_{3}$. This is due to the occurrence of Reaction (R12) that converts $\mathrm{ClO}$ and $\mathrm{NO}_{2}$ into $\mathrm{ClONO}_{2}$ at the edge of the polar vortex, which is shown by the enhanced $\mathrm{ClONO}_{2}$ area at the vortex edge in Fig. 13. Also, $\mathrm{HCl}$ and $\mathrm{ClONO}_{2}$ are depleted in the polar vortex due to the heterogeneous Reactions (R1), (R2), (R3), and (R4) on the surface of PSCs and aerosols. Some $\mathrm{HCl}$ remains near the core of the polar vortex, because the initial amount of the counterpart of the heterogeneous Reaction (R1) $\left(\mathrm{ClONO}_{2}\right)$ was less than that of $\mathrm{HCl}$, as was also shown by CLaMS, SD-WACCM, and TOMCAT/SLIMCAT model simulations by Grooß et al. (2018). The $\mathrm{O}_{3}$ amount was only slightly depleted within the polar vortex on this day.
On 2 September (day 245), amounts of $\mathrm{NO}_{2}, \mathrm{HNO}_{3}, \mathrm{HCl}$, and $\mathrm{ClONO}_{2}$ all show very depleted values in the polar vortex. The amount of $\mathrm{ClO}$ shows some enhanced values inside the polar vortex. The development of ozone depletion was seen in the polar vortex. Note that $\mathrm{ClONO}_{2}$ shows enhanced values around the boundary region of the polar vortex. This might be due to Reaction (R12) at this location. On this day (day 245), Syowa Station was located inside the polar vortex close to the vortex edge, where $\mathrm{ClO}$ was smaller and $\mathrm{ClONO}_{2}$ was greater than the values deep inside the polar vortex as observed and indicated by the upper-left circle with a cross in Fig. 10a.

On 6 September (day 249), most features were the same as on 2 September, but the shape of the polar vortex was different. Consequently, Syowa Station was located deep inside the polar vortex, where $\mathrm{ClO}$ was greater and $\mathrm{ClONO}_{2}$ was smaller than the values around the boundary region of the polar vortex as observed and indicated by the lower-right circle with a cross in Fig. 10a. Hence, the negative correlation between $\mathrm{ClO}$ and $\mathrm{ClONO}_{2}$ seen in Fig. 10 was due to variation of the relative distance between Syowa Station and the edge of the polar vortex.

As for $\mathrm{HCl}$, it remained near zero not only on this day (6 September) but also on 2 September when Syowa Sta- 
(o)

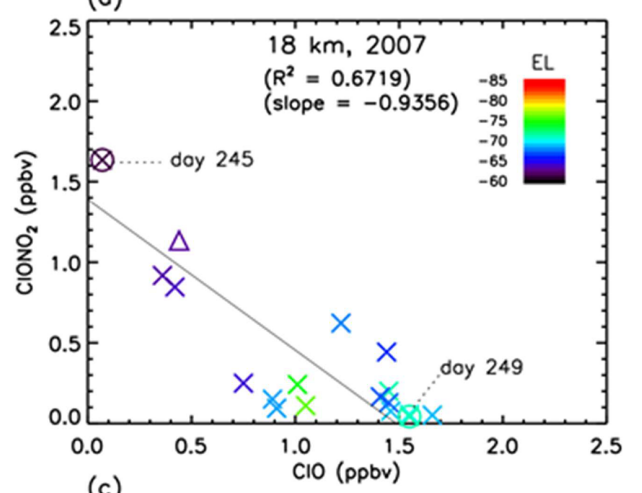

(c)

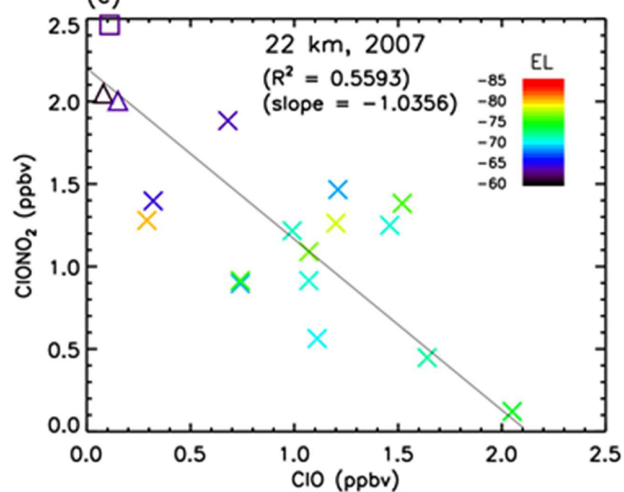

(b)

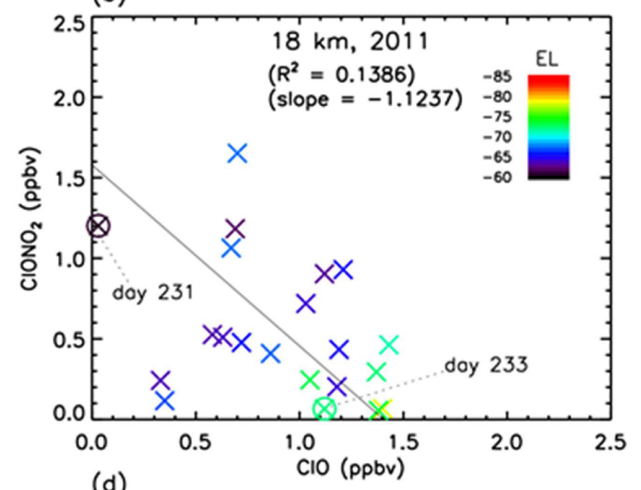

(d)

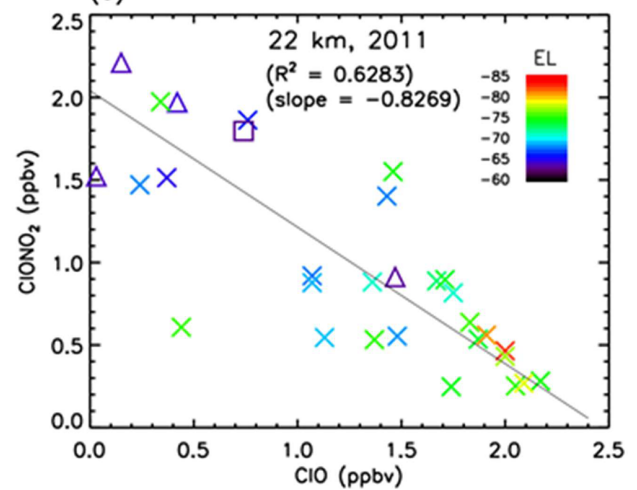

Figure 10. Scatter plot between $\mathrm{ClO}$ (Aura MLS) and $\mathrm{ClONO}_{2}$ (Envisat MIPAS) mixing ratios between 8 August and 17 September (day 220-260) at 18 and $22 \mathrm{~km}$ in 2007 and 2011. Crosses, triangles, and squares represent the data when Syowa Station was located inside the polar vortex, in the boundary region of the polar vortex, and outside the polar vortex, respectively. Solid lines are regression lines obtained by reduced major axis (RMA) regression. Color represents the equivalent latitude over Syowa Station on that day. Circles with crosses represent the days which are shown in Figs. 13 and 14.

tion was located inside the polar vortex close to the vortex edge. Therefore, observed day-to-day variations of $\mathrm{HCl}$ were small and did not show any correlation with $\mathrm{ClO}$ (see Figs. 47). A possible explanation to keep a near zero $\mathrm{HCl}$ value close to the vortex edge is due to so-called " $\mathrm{HCl}$ null cycles", which were started with Reaction (R13), proposed by Müller et al. (2018). This cycle is discussed later.

On 6 October (day 279), $\mathrm{ClO}$ enhancement has almost disappeared. Inside the polar vortex, $\mathrm{O}_{3}, \mathrm{NO}_{2}, \mathrm{HNO}_{3}$, and $\mathrm{ClONO}_{2}$ showed very low values. Ozone was almost fully destroyed at this altitude in the polar vortex. However, the amount of $\mathrm{HCl}$ increased deep inside the polar vortex. This might be due to the recovery of $\mathrm{HCl}$ by Reactions (R13) and/or (R14) deep inside the polar vortex, where there was no $\mathrm{O}_{3}$ or $\mathrm{NO}_{2}$ left and Reactions (R13) and/or (R14) were favored compared with Reaction (R12). Syowa Station was located deep inside the polar vortex, and the simulated and observed amounts of $\mathrm{HCl}$ were both more than 10 times greater than those of $\mathrm{ClONO}_{2}$ on this day (see Fig. 4).

Figure 14 shows distributions of temperature from the model nudged toward the ERA-Interim data and simulated mixing ratios of $\mathrm{O}_{3}, \mathrm{NO}_{2}, \mathrm{HNO}_{3}, \mathrm{ClO}, \mathrm{HCl}$, and $\mathrm{ClONO}_{2}$ by the MIROC3.2 CCM at $50 \mathrm{hPa}$ for 5 July (day 186), $19 \mathrm{Au}-$ gust (day 231), 21 August (day 233), and 9 October (day 282) in 2011. The polar vortex edges and location of Syowa Station were also plotted. On 5 July (day 186), the situation was similar to that of 24 June (day 175) in 2007. Note that the inner edge of the polar vortex was defined on this day. Syowa Station was located deeper inside the polar vortex on 5 July in 2011 than on 24 June in 2007, and the remaining $\mathrm{HCl}$ was observed by MLS (see Fig. 5).

On 19 August (day 231) and 21 August (day 233), the situations were similar to those of 2 September (day 245) and 6 September (day 249) in 2007, respectively. ClO and $\mathrm{ClONO}_{2}$ correlations on these days are also indicated by circles with crosses in Fig. 10b.

On 9 October (day 282), the situation was similar to that of 6 October (day 279) in 2007, but Syowa Station was located inside the polar vortex closer to the inner vortex edge than in 2007. The recovery of $\mathrm{ClONO}_{2}$ by Reaction (R12) was simulated and observed at Syowa Station in addition to the recovery of $\mathrm{HCl}$ by Reaction (R13) (see Fig. 8b), because there were some remaining $\mathrm{O}_{3}$ and $\mathrm{NO}_{2}$ air masses near the inner vortex edge (see Fig. 5). This shows the phenomena described on the last paragraph in Sect. 4.2. 

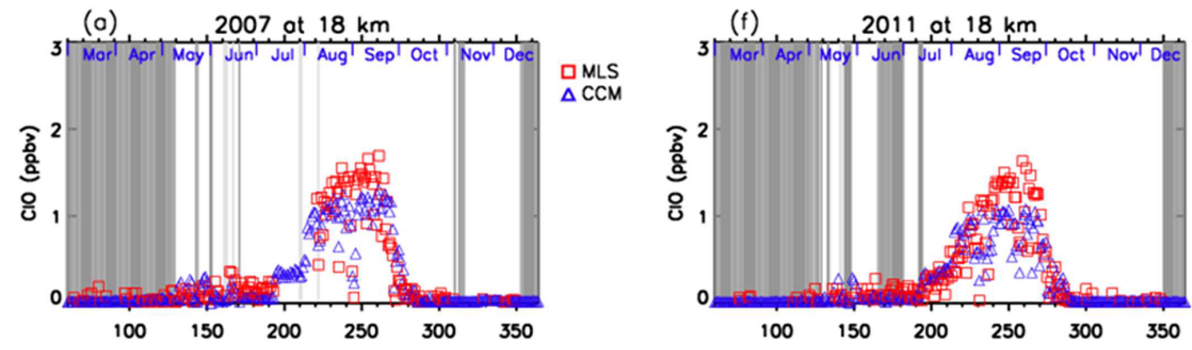

(b)
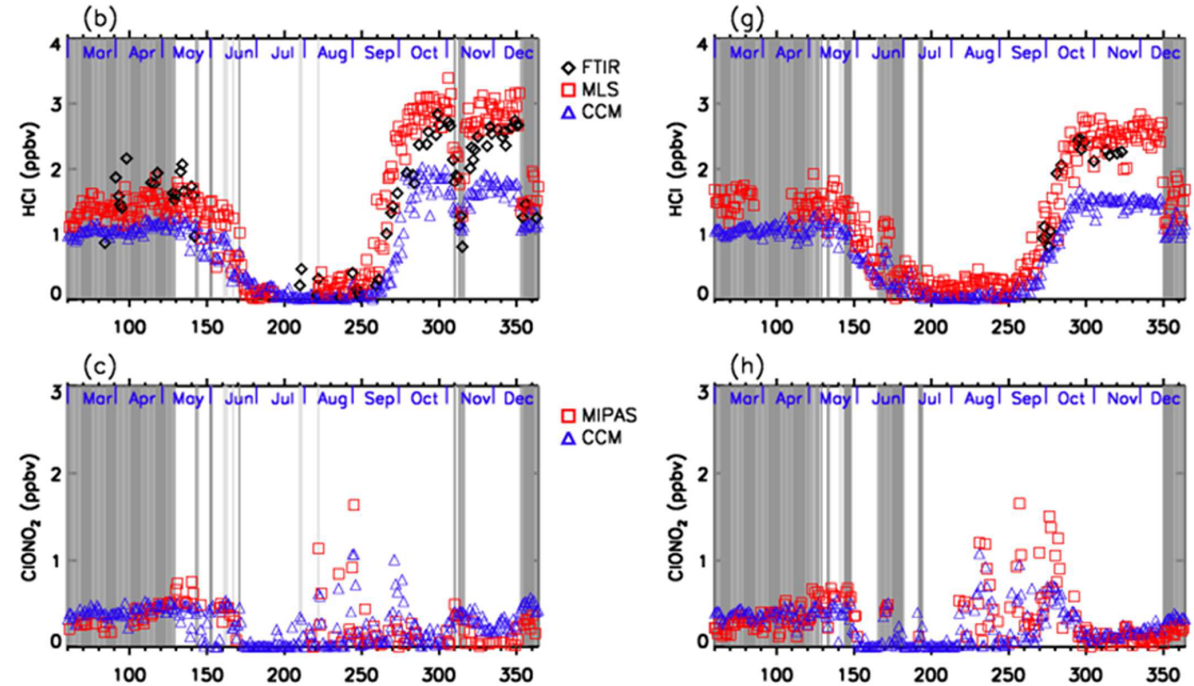

(d)

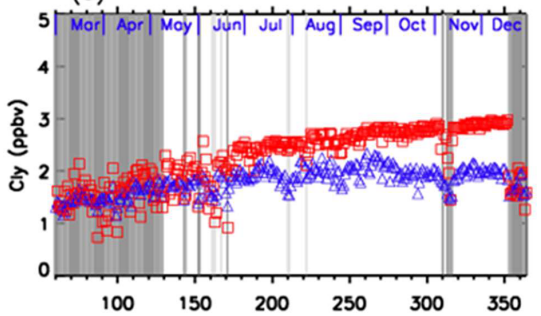

口MLS
$\triangle \mathrm{CCM}$

(e)
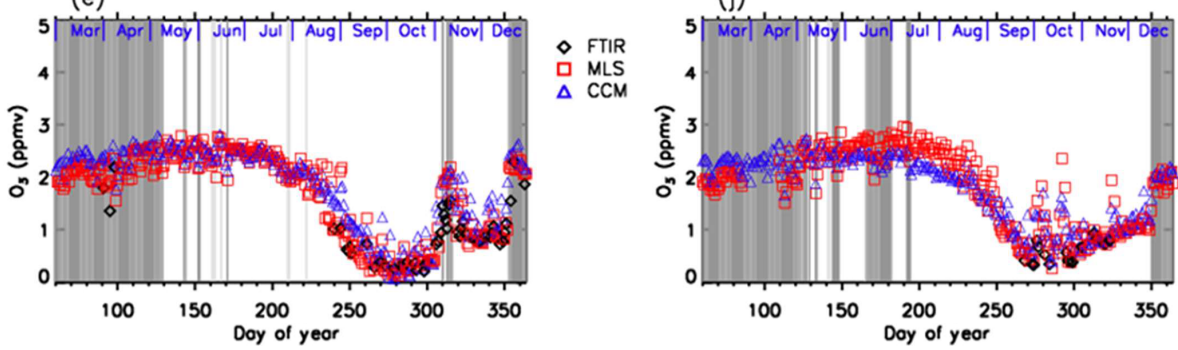

Figure 11. Daily time series of measured and modeled minor species over Syowa Station at $18 \mathrm{~km}$. Black diamonds are data by FTIR, red squares are by Aura MLS and Envisat MIPAS, blue triangles are data by MIROC3.2 CCM. Panel (a) is for $\mathrm{ClO}$, (b) is for $\mathrm{HCl}$, (c) is for $\mathrm{ClONO}_{2}$, (d) is for $\mathrm{Cl}_{y}$, and (e) is for $\mathrm{O}_{3}$ in 2007. (f) is for $\mathrm{ClO},(\mathbf{g})$ is for $\mathrm{HCl}$, (h) is for $\mathrm{ClONO}_{2}$, (i) is for $\mathrm{Cl}_{y}$, and (j) is for $\mathrm{O}_{3}$ in 2011 .

\subsection{Time evolution of chlorine species from CCM and discussion}

Three-hourly time series of zonal-mean active chlorine species, $\mathrm{Cl}_{2} \mathrm{O}_{2}$ (b), $\mathrm{Cl}_{2}$ (c), $\mathrm{ClO}$ (d), and their sum $(\mathrm{ClO}+$ $2 \cdot \mathrm{Cl}_{2} \mathrm{O}_{2}+2 \cdot \mathrm{Cl}_{2}$ ) (a), $\mathrm{HOCl}$ (e), and chlorine reservoir species $\mathrm{HCl}(\mathrm{f})$ and $\mathrm{ClONO}_{2}(\mathrm{~g})$ modeled by MIROC3.2
$\mathrm{CCM}$ at $68.4,71.2,76.7$, and $87.9^{\circ} \mathrm{S}$ in 2007 are plotted in Fig. 15. The dates on which the distribution of each species is shown in Fig. 13 are indicated by vertical dotted lines. In Fig. 15, it is shown that $\mathrm{HCl}$ and $\mathrm{ClONO}_{2}$ rapidly decreased on around 10 May (day 130) at $87.9^{\circ} \mathrm{S}$ due to the heterogeneous Reaction (R1), when PSCs started to form in the Antarctic polar vortex (Fig. 15f and g). Consequently, 

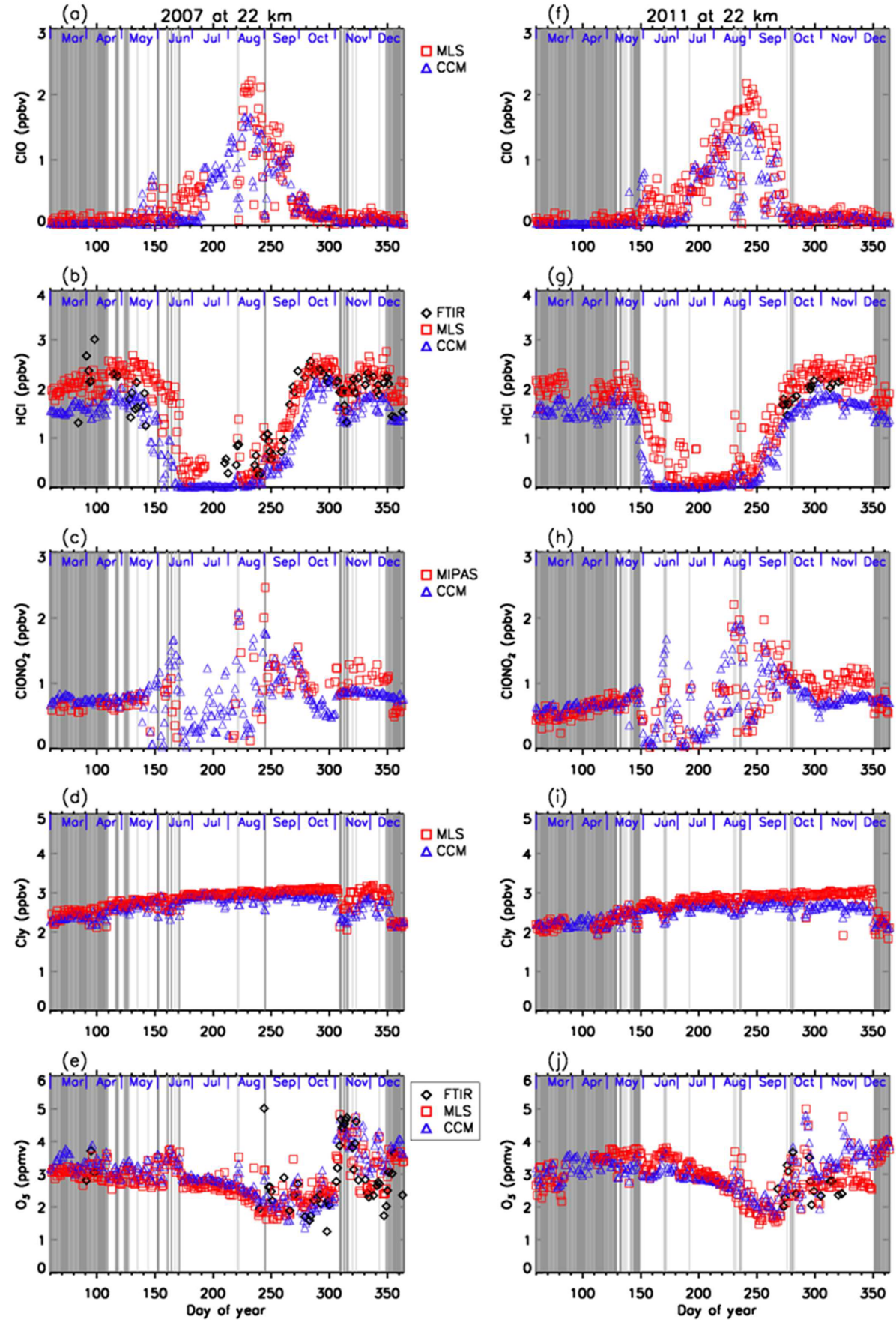

Figure 12. Same as Fig. 11 but for $22 \mathrm{~km}$.

$\mathrm{Cl}_{2}$ was formed (Fig. 15c). Similar chlorine activation was seen at $76.7^{\circ} \mathrm{S}$ about $5-10 \mathrm{~d}$ later than at $87.9^{\circ} \mathrm{S}$. The decrease in $\mathrm{HCl}$ stopped when the counterpart of the heterogeneous Reaction (R1) $\left(\mathrm{ClONO}_{2}\right)$ was missing on around 20 May (day 140). The continuous loss of $\mathrm{HCl}$ occurred from June to July (day 160-200). The possible cause of this loss will be discussed later. Gradual conversion from $\mathrm{Cl}_{2}$ into $\mathrm{Cl}_{2} \mathrm{O}_{2}$ (ClO dimer) was seen at all latitudes on around
30 May-9 June (day 150-160) (Fig. 15b and c) through Reactions (R5), (R8), and (R9). At $87.9^{\circ} \mathrm{S}$, conversion from $\mathrm{Cl}_{2}$ to $\mathrm{Cl}_{2} \mathrm{O}_{2}$ was slow, due to the lack of sunlight, which is needed for Reaction (R5). The increase in ClO occurred much later in winter (9 July; day 190 or later), because sunlight is needed to form $\mathrm{ClO}$ by Reactions (R5) and (R8) in the polar vortex (Fig. 15d). Nevertheless, there were some enhancements of $\mathrm{ClO}$ in early winter, on 24 June (day 175), 


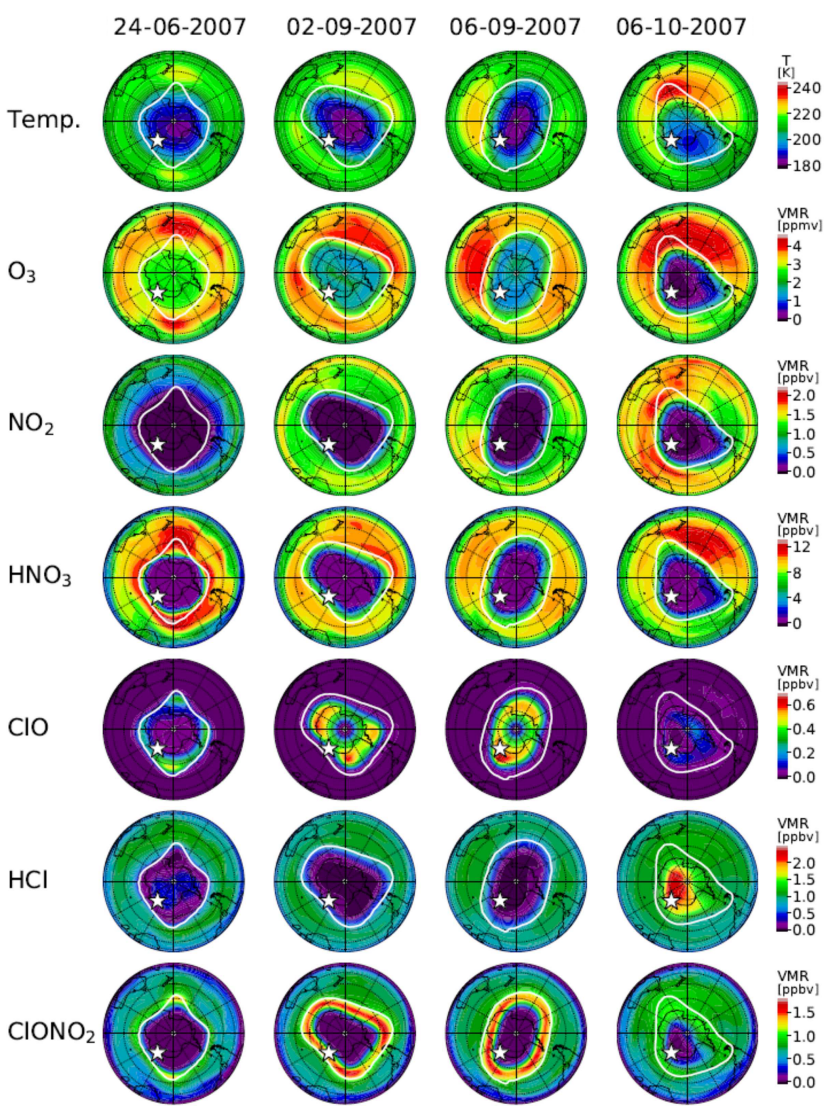

Figure 13. Polar southern hemispheric plots for ERA-Interim temperature and simulated mixing ratios of $\mathrm{O}_{3}, \mathrm{NO}_{2}, \mathrm{HNO}_{3}, \mathrm{ClO}, \mathrm{HCl}$, and $\mathrm{ClONO}_{2}$ by a MIROC3.2 chemistry-climate model (CCM) at $50 \mathrm{hPa}$ for 24 June (day 175), 2 September (day 245), 6 September (day 249), and 6 October (day 279), 2007. The polar vortex (outer) edge defined as the method described in Appendix B at $450 \mathrm{~K}$ was plotted by a white outline in each panel. The location of Syowa Station was shown by a white star in each panel.

simulated at the edge of the polar vortex (Fig. 13) where there was some sunlight available due to the distortion of the shape of the polar vortex. The increase in $\mathrm{ClO}$ occurred from a lower latitude $\left(68.4^{\circ} \mathrm{S}\right)$ on around 14 July (day 195) towards a higher latitude $\left(87.9^{\circ} \mathrm{S}\right)$ on around 12 September (day 255) (Fig. 15d). Diurnal variation of $\mathrm{ClO}$ was also seen at latitudes between 68.4 and $76.7^{\circ} \mathrm{S}$. When the stratospheric temperature increased above NAT saturation temperature on around 27 September (day 270) (Fig. 3b), chlorine activation ended, and $\mathrm{ClO}$ was mainly converted into $\mathrm{HCl}$ at all latitudes inside the polar vortex (Fig. 15d and f). This is because Reactions (R13) and/or (R14) occur more frequently than Reaction (R12) inside the polar vortex due to the depleted $\mathrm{O}_{3}$ amount there, as was described in Sect. 1 (Douglass et al., 1995). The increase in $\mathrm{HOCl}$ due to the heterogeneous Reaction (R2) on the surface of PSCs occurred gradually from June at lower latitudes (68.4 and $71.2^{\circ} \mathrm{S}$ ) (Fig. 15e). It also occurred at $76.7^{\circ} \mathrm{S}$ from July and at $87.9^{\circ} \mathrm{S}$ from August.

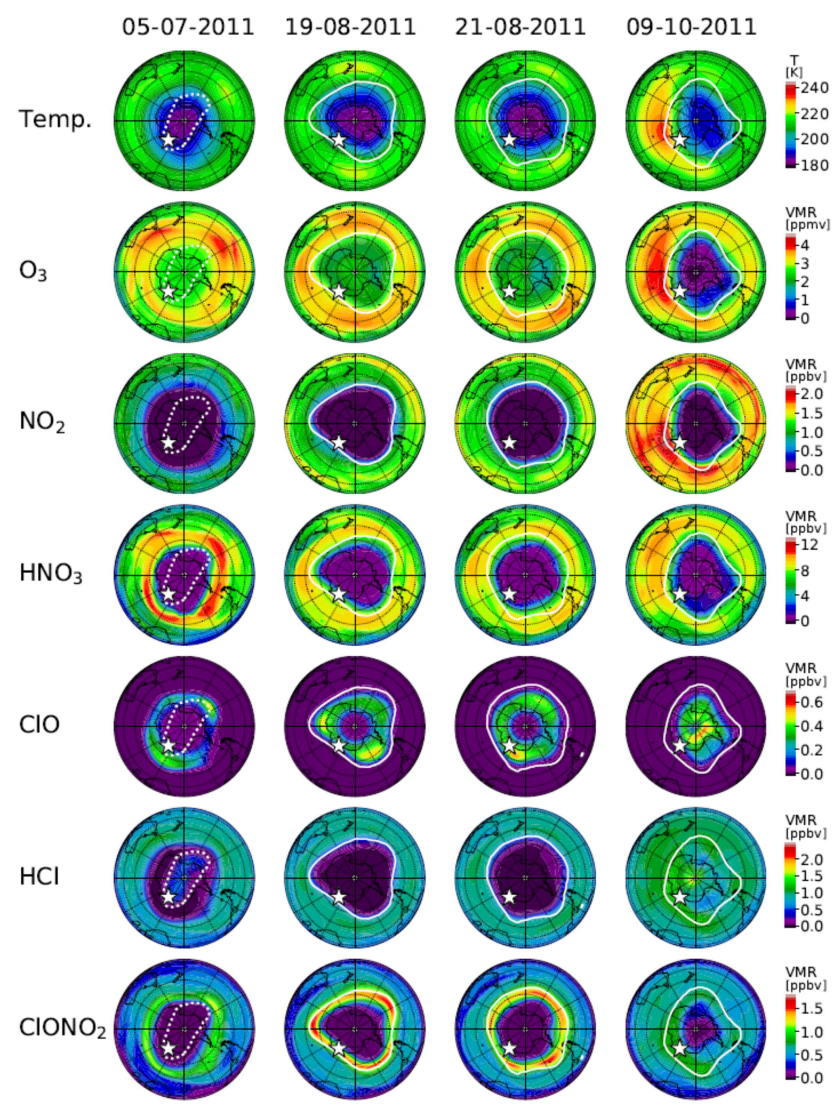

Figure 14. Same as Fig. 13 but for 5 July (day 186), 19 August (day 231), 21 August (day 233), and 9 October (day 282), 2011. The polar vortex edge on 5 July plotted by a dotted while outline indicates that the inner vortex edge was defined on this day.

The cause of the $\mathrm{HOCl}$ increase at $87.9^{\circ} \mathrm{S}$ from August is not clear at the moment. In Fig. 15, the species which decreased at $87.9^{\circ} \mathrm{S}$ from August was $\mathrm{Cl}_{2}$ (Fig. 15c). If sunlight was available, $\mathrm{Cl}_{2}$ was converted into $\mathrm{HOCl}$ through Reactions (R5) and (R8) as well as the following reaction:

$\mathrm{ClO}+\mathrm{HO}_{2} \rightarrow \mathrm{HOCl}+\mathrm{O}_{2}$.

Here, $\mathrm{HO}_{2}$ was needed to yield $\mathrm{HOCl}$. One possibility to yield $\mathrm{HO}_{2}$ in August is either one of the $\mathrm{HCl}$ null cycles $\mathrm{C}_{1}$ or $\mathrm{C}_{2}$ (see Appendix $\mathrm{C}$ ) or one of the $\mathrm{HCl}$ destruction cycles $\mathrm{C}_{3}$ or $\mathrm{C}_{4}$ (see Appendix C), which was described in Müller et al. (2018). If the air mass at $87.9^{\circ} \mathrm{S}$ was located equatorward due to the obliqueness of the polar vortex a few days earlier, then sunlight may have been available and such reactions could yield $\mathrm{HOCl}$ at $87.9^{\circ} \mathrm{S}$.

The continuous loss of $\mathrm{HCl}$ was seen at $87.9^{\circ} \mathrm{S}$ between 9 June (day 160) and 19 July (day 200) even after the disappearance of the counterpart of the heterogeneous Reaction (R1) (Fig. 15f). The cause of this continuous loss was unknown until recently, where a hypothesis was proposed that includes the effect of decomposition of particulate $\mathrm{HNO}_{3}$ by some processes like ionization of air molecules 


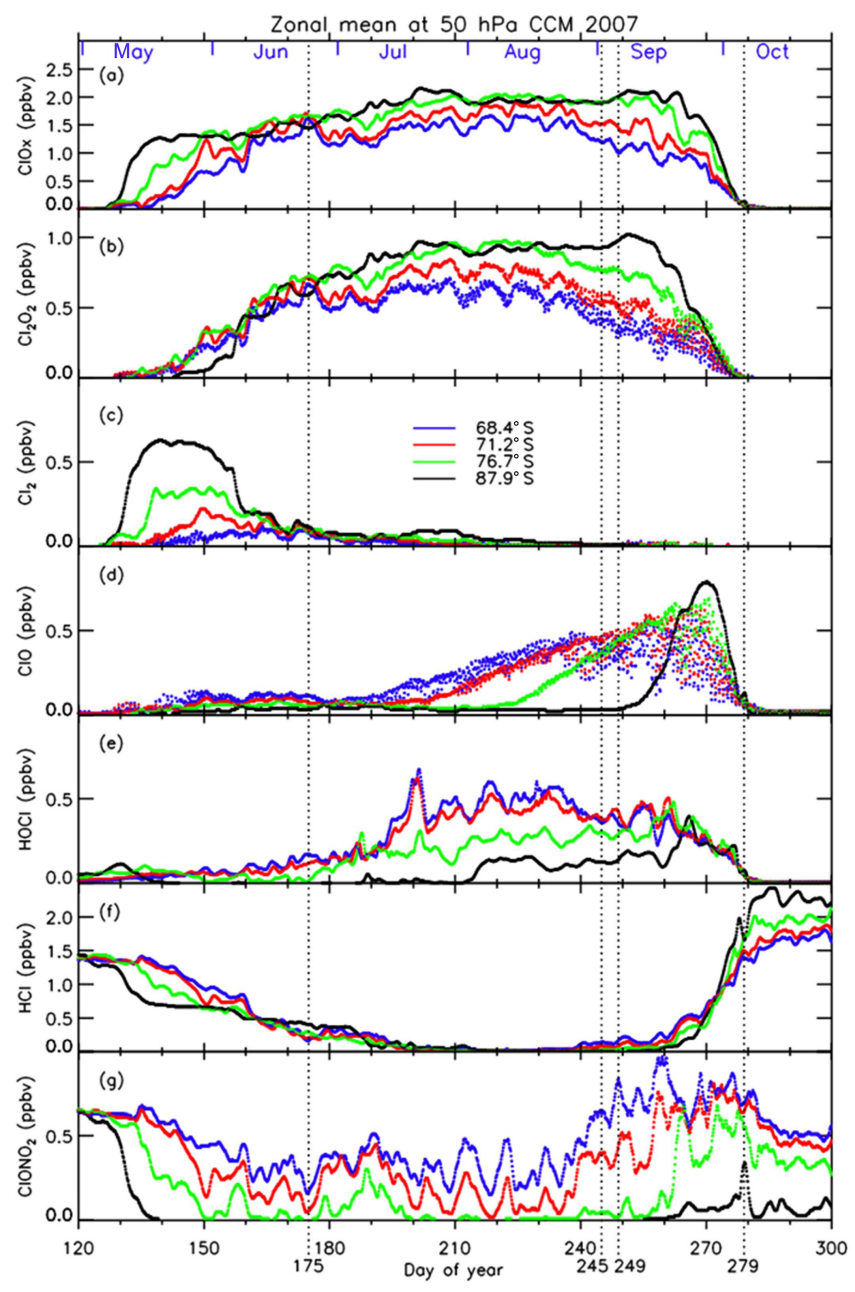

Figure 15. Three-hourly zonal-mean time series of MIROC3.2 CCM outputs for (a) $\mathrm{ClO}+2 \cdot \mathrm{Cl}_{2} \mathrm{O}_{2}+2 \cdot \mathrm{Cl}_{2}$, (b) $\mathrm{Cl}_{2} \mathrm{O}_{2}$, (c) $\mathrm{Cl}_{2}$, (d) $\mathrm{ClO}$, (e) $\mathrm{HOCl}$, (f) $\mathrm{HCl}$, and (g) $\mathrm{ClONO}_{2}$ during day number $120-300$ at $50 \mathrm{hPa}$ in 2007.

caused by galactic cosmic rays during the winter polar vortex or photolysis of dissolved $\mathrm{HNO}_{3}$ in PSC particles (Grooß et al., 2018). However, they concluded that these processes could not explain the $\mathrm{HCl}$ discrepancy between their models and observations. We consider that the continuous loss of $\mathrm{HCl}$ was caused by the mixing of $\mathrm{ClONO}_{2}$-containing air with the air at the core of the polar vortex, due to the excursions of air parcels in and out of sunlight during the winter caused by the distortion of the polar vortex, which photochemically resupply $\mathrm{ClONO}_{2}$ and $\mathrm{HOCl}$. Our result was indicated by some sporadic increase in $\mathrm{ClONO}_{2}$ on around 7 June (day 158), 28 June (day 179), and 8 July (day 189) at $76.7^{\circ} \mathrm{S}$ as shown in Fig. 15g. We confirmed that the shapes of the polar vortex were rather distorted on these days. Subsequently, $\mathrm{HCl}$ losses were observed at 76.7 and $87.9^{\circ} \mathrm{S}$ during these episodes in Fig. 15f. Thus, the continuous loss of $\mathrm{HCl}$ at the most polar latitude $\left(87.9^{\circ} \mathrm{S}\right)$ could be due to the grad- ual mixing of air within the polar vortex during the winter period, when the polar vortex was still strong.

The $\mathrm{ClONO}_{2}$ distribution on 24 June 2007 in Fig. 13 shows a peak at around the polar vortex outer edge (equivalent latitude of $\sim 62^{\circ} \mathrm{S}$ ) where there was no $\mathrm{HCl}$. We confirmed that such a peak continued to exist from the middle of June to the end of July, when sunlight was not available at a geographical latitude higher than $70^{\circ} \mathrm{S}$ due to polar night. However, a substantial amount of $\mathrm{ClONO}_{2}$ exists between an equivalent latitude of $62^{\circ} \mathrm{S}$ (polar vortex outer edge) and $70^{\circ} \mathrm{S}$, mainly due to the distortion of the polar vortex and availability of $\mathrm{O}_{3}$. At $62^{\circ} \mathrm{S}$ equivalent latitude, the amount of $\mathrm{ClONO}_{2}$ has a peak around these days, while $\mathrm{HCl}$ amounts were low. At around $65-70^{\circ} \mathrm{S}, \mathrm{HCl}$ was almost fully depleted. Therefore, if the air mass which contains some $\mathrm{ClONO}_{2}$ traveled poleward due to mixing, it could react with $\mathrm{HCl}$ by Reaction (R1) and continuously destroy $\mathrm{HCl}$ in the core of the polar vortex during the polar night in June and July. Another explanation for the loss of $\mathrm{HCl}$ is the heterogeneous Reaction (R4) on the surface of PSCs with $\mathrm{HOCl}$. Spiky increases in $\mathrm{HOCl}$ at 76.7 and $87.9^{\circ} \mathrm{S}$ and a simultaneous decrease in $\mathrm{HCl}$ occurred on around 7 July (day 188) and 20 July (day 201) in Fig. 15e and f. The continuous loss of $\mathrm{HCl}$ at the core of the polar vortex in August and September was recently proposed by Müller et al. (2018), who proposed that $\mathrm{HCl}$ destruction cycles $\mathrm{C}_{3}$ and $\mathrm{C}_{4}$ (see Appendix $\mathrm{C}$ ) are responsible for the decline of $\mathrm{HCl}$ in the vortex core. These chemical cycles also require sunlight to occur, which may not be available in June and July at the vortex core. Therefore, the distortion of the polar vortex is also important for that reaction to occur as well. We consider that the reactions of $\mathrm{HCl}$ with both $\mathrm{ClONO}_{2}$ and $\mathrm{HOCl}$ contribute the continuous loss of $\mathrm{HCl}$ during winter in the vortex core.

Recently, Solomon et al. (2015) discussed the race between chlorine activation and deactivation to maintain enhanced levels of active chlorine during the time period (September and early October) when rapid ozone loss occurs. Müller et al. (2018) proposed so-called $\mathrm{HCl}$ null cycles to maintain enhanced chlorine levels. They proposed a mechanism in which the formation of $\mathrm{HCl}$ (Reaction R13) is followed by the immediate reactivation of $\mathrm{HCl}$ by null cycles $C_{1}$ and $C_{2}$ (see Appendix C) (Müller et al., 2018). Our MIROC3.2 CCM model results support the mechanism by high $\mathrm{ClO}$ and $\mathrm{HOCl}$ levels in September as shown in Fig. 15d and e.

\section{Conclusions}

Lower stratospheric vertical profiles of $\mathrm{O}_{3}, \mathrm{HNO}_{3}$, and $\mathrm{HCl}$ were retrieved using SFIT2 from solar spectra taken with a ground-based FTIR installed at Syowa Station, Antarctica, from March to December 2007 and September to November 2011. This was the first continuous measurement of chlorine species throughout the ozone hole period from the ground 
in Antarctica. Retrieved profiles were validated with Aura MLS and ozonesonde data. The absolute differences between FTIR and Aura MLS or ozonesonde measurements were within measurement error bars at the altitudes of interest.

To study the temporal variation of chlorine partitioning and ozone destruction from fall to spring in the Antarctic polar vortex, we analyzed temporal variations of measured minor species using FTIR over Syowa Station combined with satellite measurements of $\mathrm{ClO}, \mathrm{HCl}, \mathrm{ClONO}_{2}$ and $\mathrm{HNO}_{3}$. When the stratospheric temperature over Syowa Station fell $\sim 4 \mathrm{~K}$ below NAT saturation temperature, PSCs started to form and the heterogeneous reaction between $\mathrm{HCl}$ and $\mathrm{ClONO}_{2}$ occurred, and eventually, in early winter, both $\mathrm{HCl}$ and $\mathrm{ClONO}_{2}$ were almost completely depleted at both 18 and $22 \mathrm{~km}$. When the sun came back to the Antarctic in spring, enhancement of $\mathrm{ClO}$ and gradual $\mathrm{O}_{3}$ destruction were observed. During the $\mathrm{ClO}$-enhanced period, a negative correlation between $\mathrm{ClO}$ and $\mathrm{ClONO}_{2}$ was observed in the time series of the data at Syowa Station. This negative correlation is associated with the relative distance between Syowa Station and the edge of the polar vortex.

To investigate the behavior of whole chlorine and related species inside the polar vortex and the boundary region in more detail, results of the MIROC3.2 CCM simulation were analyzed. The direct comparison between CCM results and observations shows good day-to-day agreement in general, although some species show systematic differences especially at $18 \mathrm{~km}$. The modeled $\mathrm{O}_{3}$ is in good agreement with FTIR and satellite observations. Rapid conversion of chlorine reservoir species $\left(\mathrm{HCl}\right.$ and $\left.\mathrm{ClONO}_{2}\right)$ into $\mathrm{Cl}_{2}$, gradual conversion of $\mathrm{Cl}_{2}$ into $\mathrm{Cl}_{2} \mathrm{O}_{2}$, increase in $\mathrm{HOCl}$ in the winter period, increase in $\mathrm{ClO}$ when sunlight became available, and conversion of $\mathrm{ClO}$ into $\mathrm{HCl}$ were successfully reproduced by the CCM. The $\mathrm{HCl}$ decrease in the winter polar vortex core continued to occur due to both transport of $\mathrm{ClONO}_{2}$ from the polar vortex boundary region to higher latitudes, providing a flux of $\mathrm{ClONO}_{2}$ from more sunlit latitudes into the polar vortex, and the heterogeneous reaction of $\mathrm{HCl}$ with $\mathrm{HOCl}$. The temporal variation of chlorine species over Syowa Station was affected by both heterogeneous chemistries related to PSC occurrence inside the polar vortex and transport of a $\mathrm{NO}_{x}$-rich air mass from the polar vortex boundary region, which can produce additional $\mathrm{ClONO}_{2}$ via Reaction (R12).
The deactivation pathways from active $\mathrm{ClO}$ into reservoir species $\left(\mathrm{HCl}\right.$ and/or $\left.\mathrm{ClONO}_{2}\right)$ were confirmed to be very dependent on the availability of ambient $\mathrm{O}_{3}$. At $18 \mathrm{~km}$, where most ozone was depleted, most $\mathrm{ClO}$ was converted to $\mathrm{HCl}$. At $22 \mathrm{~km}$, when some $\mathrm{O}_{3}$ was available, an additional increase in $\mathrm{ClONO}_{2}$ than the prewinter value occurred, similar to the Arctic, through Reactions (R15) and (R12) (Douglass et al., 1995; Grooß et al., 1997). 
Appendix A: MIROC3.2 nudged chemistry-climate model

The chemistry-climate model used in this study was the MIROC3.2 CCM, which was developed on the basis of version 3.2 of the Model for Interdisciplinary Research on Climate (MIROC3.2) general circulation model (GCM). The MIROC3.2 CCM introduces the stratospheric chemistry module of the old version of the CCM that was used for simulations proposed by the chemistry-climate model validation (CCMVal) and the second round of CCMVal (CCMVal2) (WMO, 2007, 2011; SPARC CCMVal, 2010; Akiyoshi et al., 2009, 2010). The MIROC3.2 CCM is a spectral model with a T42 horizontal resolution $\left(2.8^{\circ} \times 2.8^{\circ}\right)$ and 34 vertical atmospheric layers above the surface. The top layer is located at approximately $80 \mathrm{~km}(0.01 \mathrm{hPa})$. Hybrid sigmapressure coordinates are used for the vertical coordinate. The horizontal wind velocity and temperature in the CCM were nudged toward the ERA-Interim data (Dee et al., 2011) to simulate global distributions of ozone and other chemical constituents on a daily basis. The transport is calculated by a semi-Lagrangian scheme (Lin and Rood, 1996). The chemical constituents included in this model are $\mathrm{O}_{x}, \mathrm{HO}_{x}, \mathrm{NO}_{x}$, $\mathrm{ClO}_{x}, \mathrm{BrO}_{x}$, hydrocarbons for methane oxidation, heterogeneous reactions on the surface for sulfuric acid aerosols, supercooled ternary solutions, nitric acid trihydrate, and ice particles.
The CCM contains 13 heterogeneous reactions on multiple aerosol types (Akiyoshi, 2007) as well as gas-phase chemical reactions and photolysis reactions. The surface of the particles for the heterogeneous reactions is calculated from the volume of condensation, assuming number density of the particles and the size distributions. Additionally, sedimentation of the particles is considered. The reaction-rate and absorption coefficients are based on JPL-2010 (Sander et al., 2011). The family method is used to calculate gas-phase chemical reactions. The time integrations for the families and heterogeneous reactions are performed explicitly. The time step for the chemistry scheme is $6 \mathrm{~min}$. A scheme of spherical geometry for radiation transfer was developed (Kurokawa et al., 2005) and used for radiation transfer calculation in the CCM. The photolysis rates of chemical constituents are calculated online, using the radiation flux in the CCM with 32 spectral bins. All the 42 photolysis reactions, 140 gas-phase reactions, and 13 heterogeneous reactions are summarized in Table A2. See Akiyoshi et al. (2016) and the Supplement of Morgenstern et al. (2017) for more details.

Table A1. FTIR observation dates at Syowa Station in 2007 and 2011.

\begin{tabular}{|c|c|c|c|c|c|c|}
\hline Month & $\begin{array}{l}\text { Dates } \\
(2007)\end{array}$ & $\begin{array}{l}\text { Dates } \\
(2011)\end{array}$ & $\begin{array}{l}\text { Number of } \\
\text { days inside the } \\
\text { polar vortex } \\
(2007 / 2011)\end{array}$ & $\begin{array}{l}\text { Number of } \\
\text { days in the } \\
\text { boundary region } \\
\text { of the polar } \\
\text { vortex } \\
(2007 / 2011)\end{array}$ & $\begin{array}{l}\text { Number of } \\
\text { days outside the } \\
\text { polar vortex } \\
(2007 / 2011)\end{array}$ & $\begin{array}{l}\text { Number of } \\
\text { measurement } \\
\text { days } \\
(2007 / 2011)\end{array}$ \\
\hline Mar & 25 & & $0 / 0$ & $0 / 0$ & $1 / 0$ & $1 / 0$ \\
\hline Apr & $\begin{array}{l}1,3,4,5,8,24,26 \\
28\end{array}$ & & $0 / 0$ & $0 / 0$ & $8 / 0$ & $8 / 0$ \\
\hline May & $\begin{array}{l}8,9,10,13,14,15 \\
20,21,22\end{array}$ & & $7 / 0$ & $0 / 0$ & $2 / 0$ & $9 / 0$ \\
\hline Jun & & & $0 / 0$ & $0 / 0$ & $0 / 0$ & $0 / 0$ \\
\hline Jul & 29,30 & & $0 / 0$ & $2 / 0$ & $0 / 0$ & $2 / 0$ \\
\hline Aug & $\begin{array}{l}1,8,9,10,24,25 \\
26,28,29\end{array}$ & & $8 / 0$ & $1 / 0$ & $0 / 0$ & $9 / 0$ \\
\hline Sep & $\begin{array}{l}1,4,5,6,7,8,16 \\
18,23,26,27,30\end{array}$ & $25,29,30$ & $12 / 3$ & $0 / 0$ & $0 / 0$ & $12 / 3$ \\
\hline Oct & $\begin{array}{l}6,10,11,14,19 \\
20,25,26,27\end{array}$ & $\begin{array}{l}1,3,4,8,11,22,23 \\
24,26\end{array}$ & $9 / 9$ & $0 / 0$ & $0 / 0$ & $9 / 9$ \\
\hline Nov & $\begin{array}{l}2,3,5,6,7,8,9,10 \\
11,16,17,18,19 \\
21,27,29,30\end{array}$ & $1,2,3,9,11,16,19$ & $12 / 7$ & $1 / 0$ & $4 / 0$ & $17 / 7$ \\
\hline Dec & $\begin{array}{l}4,7,8,9,13,15,16 \\
17,20,22,29\end{array}$ & & $8 / 0$ & $0 / 0$ & $3 / 0$ & $11 / 0$ \\
\hline Total & & & $56 / 19$ & $4 / 0$ & $18 / 0$ & $78 / 19$ \\
\hline
\end{tabular}


Table A2. Chemical reactions in the MIROC3.2 chemistry-climate model.

\begin{tabular}{|c|c|}
\hline (1) Photolysis reactions & Reaction coefficients (reference) \\
\hline $\mathrm{O}_{2}+h v \rightarrow \mathrm{O}\left({ }^{1} \mathrm{D}\right)+\mathrm{O}$ & JPL-2010 \\
\hline $\mathrm{O}_{2}+h v \rightarrow 2 \mathrm{O}$ & JPL-2010 \\
\hline $\mathrm{O}_{3}+h v \rightarrow \mathrm{O}\left({ }^{1} \mathrm{D}\right)+\mathrm{O}_{2}$ & JPL-2010 \\
\hline $\mathrm{O}_{3}+h v \rightarrow \mathrm{O}+\mathrm{O}_{2}$ & JPL-2010 \\
\hline $\mathrm{H}_{2} \mathrm{O}+h v \rightarrow \mathrm{OH}+\mathrm{H}$ & JPL-2010 \\
\hline $\mathrm{CH}_{3} \mathrm{OOH}+h v \rightarrow \mathrm{CH}_{3} \mathrm{O}+\mathrm{OH}$ & JPL-2010 \\
\hline $\mathrm{CH}_{2} \mathrm{O}+h v \rightarrow \mathrm{CHO}+\mathrm{H}$ & JPL-2010 \\
\hline $\mathrm{CH}_{2} \mathrm{O}+h v \rightarrow \mathrm{CO}+\mathrm{H}_{2}$ & JPL-2010 \\
\hline $\mathrm{H}_{2} \mathrm{O}_{2}+h v \rightarrow 2 \mathrm{OH}$ & JPL-2010 \\
\hline $\mathrm{N}_{2} \mathrm{O}+h v \rightarrow \mathrm{N}_{2}+\mathrm{O}\left({ }^{1} \mathrm{D}\right)$ & JPL-2010 \\
\hline $\mathrm{NO}+h v \rightarrow \mathrm{N}+\mathrm{O}$ & JPL-2010 \\
\hline $\mathrm{NO}_{3}+h v \rightarrow \mathrm{NO}_{2}+\mathrm{O}$ & JPL-2010 \\
\hline $\mathrm{NO}_{3}+h v \rightarrow \mathrm{NO}+\mathrm{O}_{2}$ & JPL-2010 \\
\hline $\mathrm{HNO}_{3}+h v \rightarrow \mathrm{OH}+\mathrm{NO}_{2}$ & JPL-2010 \\
\hline $\mathrm{HNO}_{4}+h v \rightarrow \mathrm{OH}+\mathrm{NO}_{3}$ & JPL-2010 \\
\hline $\mathrm{HNO}_{4}+h v \rightarrow \mathrm{HO}_{2}+\mathrm{NO}_{2}$ & JPL-2010 \\
\hline $\mathrm{N}_{2} \mathrm{O}_{5}+h v \rightarrow \mathrm{NO}_{2}+\mathrm{NO}_{3}$ & JPL-2010 \\
\hline $\mathrm{HCl}+h v \rightarrow \mathrm{H}+\mathrm{Cl}$ & JPL-2010 \\
\hline $\mathrm{HOCl}+h v \rightarrow \mathrm{OH}+\mathrm{Cl}$ & JPL-2010 \\
\hline $\mathrm{ClONO}_{2}+h v \rightarrow \mathrm{Cl}+\mathrm{NO}_{3}$ & JPL-2010 \\
\hline $\mathrm{ClONO}_{2}+h v \rightarrow \mathrm{O}+\mathrm{ClONO}$ & JPL-2010 \\
\hline $\mathrm{Cl}_{2} \mathrm{O}_{2}+h v \rightarrow \mathrm{ClOO}+\mathrm{Cl}$ & JPL-2010 \\
\hline $\mathrm{OClO}+h v \rightarrow \mathrm{O}+\mathrm{ClO}$ & JPL-2010 \\
\hline $\mathrm{Cl}_{2}+h v \rightarrow 2 \mathrm{Cl}$ & JPL-2010 \\
\hline $\mathrm{BrONO}_{2}+h v \rightarrow \mathrm{BrO}+\mathrm{NO}_{2}$ & JPL-2010 \\
\hline $\mathrm{BrONO}_{2}+h v \rightarrow \mathrm{Br}+\mathrm{NO}_{3}$ & JPL-2010 \\
\hline $\mathrm{BrCl}+h v \rightarrow \mathrm{Br}+\mathrm{Cl}$ & JPL-2010 \\
\hline $\mathrm{HOBr}+h v \rightarrow \mathrm{Br}+\mathrm{OH}$ & JPL-2010 \\
\hline $\mathrm{BrO}+h v \rightarrow \mathrm{Br}+\mathrm{O}$ & JPL-2010 \\
\hline $\mathrm{HBr}+h v \rightarrow \mathrm{Br}+\mathrm{H}$ & JPL-2010 \\
\hline $\mathrm{Br}_{2}+h v \rightarrow 2 \mathrm{Br}$ & JPL-2010 \\
\hline $\mathrm{CCl}_{4}+h v \rightarrow 4 \mathrm{Cl}+$ products & JPL-2010 \\
\hline $\mathrm{CH}_{3} \mathrm{CCl}_{3}+h v \rightarrow 3 \mathrm{Cl}+$ products & JPL-2010 \\
\hline $\mathrm{CH}_{3} \mathrm{Cl}+h v \rightarrow \mathrm{Cl}+$ products & JPL-2010 \\
\hline $\mathrm{CFCl}_{3}(\mathrm{CFC}-11)+h v \rightarrow 3 \mathrm{Cl}+$ products & JPL-2010 \\
\hline $\mathrm{CF}_{2} \mathrm{Cl}_{2}(\mathrm{CFC}-12)+h v \rightarrow 2 \mathrm{Cl}+$ products & JPL-2010 \\
\hline $\mathrm{CClF}_{2} \mathrm{CCl}_{2} \mathrm{~F}(\mathrm{CFC}-113)+h v \rightarrow 3 \mathrm{Cl}+$ products & JPL-2010 \\
\hline $\mathrm{CHClF}_{2}(\mathrm{HCFC}-22)+h v \rightarrow \mathrm{Cl}+$ products & JPL-2010 \\
\hline $\mathrm{CHBr}_{3}+h v \rightarrow 3 \mathrm{Br}+$ products & JPL-2010 \\
\hline $\mathrm{CH}_{3} \mathrm{Br}+h v \rightarrow \mathrm{Br}+$ products & JPL-2010 \\
\hline $\mathrm{CF}_{2} \mathrm{ClBr}($ Halon-1211) $+h v \rightarrow \mathrm{Br}+\mathrm{Cl}+$ products & JPL-2010 \\
\hline $\mathrm{CF}_{3} \mathrm{Br}($ Halon-1301) $+h v \rightarrow \mathrm{Br}+$ products & JPL-2010 \\
\hline (2) Gas-phase reactions & Reaction coefficients (reference) \\
\hline $\mathrm{O}+\mathrm{O}+M \rightarrow \mathrm{O}_{2}+M$ & Brasseur and Solomon (1986) \\
\hline $\mathrm{O}+\mathrm{O}_{2}+M \rightarrow \mathrm{O}_{3}+M$ & see JPL-2010 \\
\hline $\mathrm{O}+\mathrm{O}_{3} \rightarrow \mathrm{O}_{2}+\mathrm{O}_{2}$ & $8.0 \times 10^{-12} \exp [-2060 / T]$ \\
\hline $\mathrm{O}\left({ }^{1} \mathrm{D}\right)+\mathrm{N}_{2} \rightarrow \mathrm{O}+\mathrm{N}_{2}$ & $2.15 \times 10^{-11} \exp [110 / T]$ \\
\hline $\mathrm{O}\left({ }^{1} \mathrm{D}\right)+\mathrm{O}_{2} \rightarrow \mathrm{O}+\mathrm{O}_{2}$ & $3.3 \times 10^{-11} \exp [55 / T]$ \\
\hline $\mathrm{H}_{2} \mathrm{O}+\mathrm{O}\left({ }^{1} \mathrm{D}\right) \rightarrow 2 \mathrm{OH}$ & $1.63 \times 10^{-10} \exp [60 / T]$ \\
\hline $\mathrm{H}_{2}+\mathrm{O}\left({ }^{1} \mathrm{D}\right) \rightarrow \mathrm{H}+\mathrm{OH}$ & $1.2 \times 10^{-10}$ \\
\hline $\mathrm{CH}_{4}+\mathrm{O}\left({ }^{1} \mathrm{D}\right) \rightarrow \mathrm{CH}_{3}+\mathrm{OH}$ & $1.75 \times 10^{-10}$ \\
\hline $\mathrm{CH}_{4}+\mathrm{OH} \rightarrow \mathrm{CH}_{3}+\mathrm{H}_{2} \mathrm{O}$ & see JPL-2010 \\
\hline $\mathrm{CH}_{3}+\mathrm{O}_{2}+M \rightarrow \mathrm{CH}_{3} \mathrm{O}_{2}+M$ & see JPL-2010 \\
\hline $\mathrm{CH}_{3}+\mathrm{O} \rightarrow \mathrm{CH}_{2} \mathrm{O}+\mathrm{H}$ & $1.1 \times 10^{-10}$ \\
\hline $\mathrm{CH}_{3} \mathrm{O}_{2}+\mathrm{CH}_{3} \mathrm{O}_{2} \rightarrow$ products & $9.5 \times 10^{-14} \exp [390 / T]$ \\
\hline
\end{tabular}


Table A2. Continued.

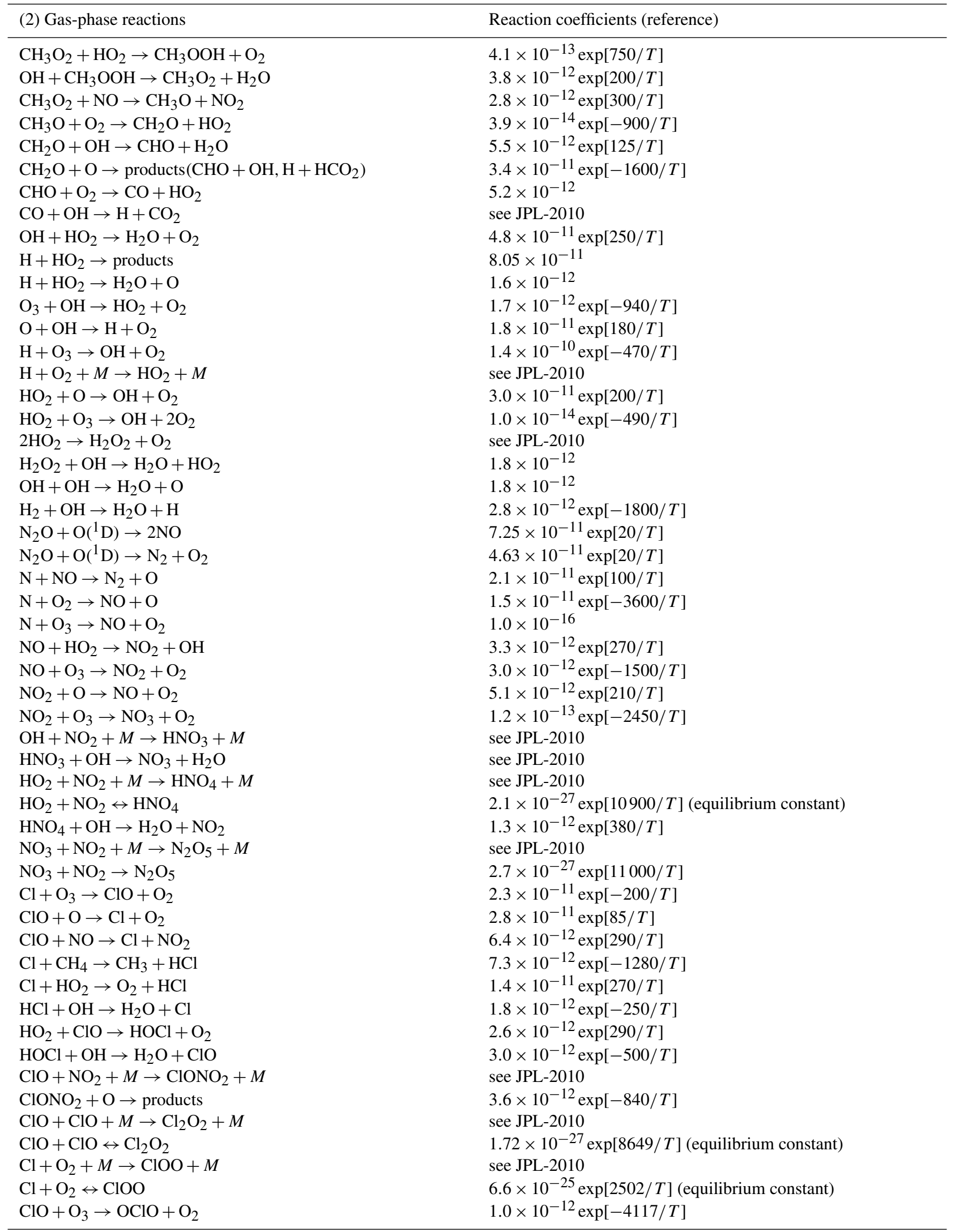


Table A2. Continued.

\begin{tabular}{|c|c|}
\hline (2) Gas-phase reactions & Reaction coefficients (reference) \\
\hline $\mathrm{OClO}+\mathrm{Cl} \rightarrow \mathrm{ClO}+\mathrm{ClO}$ & $3.4 \times 10^{-11} \exp [160 / T]$ \\
\hline $\mathrm{OClO}+\mathrm{OH} \rightarrow \mathrm{HOCl}+\mathrm{O}_{2}$ & $1.4 \times 10^{-12} \exp [600 / T]$ \\
\hline $\mathrm{OClO}+\mathrm{NO} \rightarrow \mathrm{ClO}+\mathrm{NO}_{2}$ & $2.5 \times 10^{-12} \exp [-600 / T]$ \\
\hline $\mathrm{OClO}+\mathrm{O} \rightarrow \mathrm{ClO}+\mathrm{O}_{2}$ & $2.4 \times 10^{-12} \exp [-960 / T]$ \\
\hline $\mathrm{Cl}+\mathrm{H}_{2} \rightarrow \mathrm{H}+\mathrm{HCl}$ & $3.05 \times 10^{-11} \exp [-2270 / T]$ \\
\hline $\mathrm{Cl}+\mathrm{H}_{2} \mathrm{O}_{2} \rightarrow \mathrm{HCl}+\mathrm{HO}_{2}$ & $1.1 \times 10^{-11} \exp [-980 / T]$ \\
\hline $\mathrm{Cl}+\mathrm{CH}_{2} \mathrm{O} \rightarrow \mathrm{CHO}+\mathrm{HCl}$ & $8.1 \times 10^{-11} \exp [-30 / T]$ \\
\hline $\mathrm{HCl}+\mathrm{O} \rightarrow \mathrm{OH}+\mathrm{Cl}$ & $1.0 \times 10^{-11} \exp [-3300 / T]$ \\
\hline $\mathrm{Cl}+\mathrm{HO}_{2} \rightarrow \mathrm{Cl}_{2}+\mathrm{OH}$ & $3.6 \times 10^{-11} \exp [-375 / T]$ \\
\hline $\mathrm{Cl}+\mathrm{HOCl} \rightarrow$ products $\left(\mathrm{Cl}_{2}+\mathrm{OH}, \mathrm{HCl}+\mathrm{ClO}\right)$ & $3.4 \times 10^{-12} \exp [-130 / T]$ \\
\hline $\mathrm{HOCl}+\mathrm{O} \rightarrow \mathrm{OH}+\mathrm{ClO}$ & $1.7 \times 10^{-13}$ \\
\hline $\mathrm{ClO}+\mathrm{ClO} \rightarrow \mathrm{Cl}_{2}+\mathrm{O}_{2}$ & $1.0 \times 10^{-12} \exp [-1590 / T]$ \\
\hline $\mathrm{ClO}+\mathrm{ClO} \rightarrow \mathrm{OClO}+\mathrm{Cl}$ & $3.5 \times 10^{-13} \exp [-1370 / T]$ \\
\hline $\mathrm{ClO}+\mathrm{ClO} \rightarrow \mathrm{ClOO}+\mathrm{Cl}$ & $3.0 \times 10^{-11} \exp [-2450 / T]$ \\
\hline $\mathrm{ClO}+\mathrm{OH} \rightarrow \mathrm{Cl}+\mathrm{HO}_{2}$ & $7.4 \times 10^{-12} \exp [270 / T]$ \\
\hline $\mathrm{ClO}+\mathrm{OH} \rightarrow \mathrm{HCl}+\mathrm{O}_{2}$ & $6.0 \times 10^{-13} \exp [230 / T]$ \\
\hline $\mathrm{CH}_{2} \mathrm{O}+\mathrm{Cl} \rightarrow \mathrm{HCl}+\mathrm{CHO}$ & $8.1 \times 10^{-11} \exp [-30 / T]$ \\
\hline $\mathrm{CH}_{3} \mathrm{O}_{2}+\mathrm{ClO} \rightarrow$ products $\left(\mathrm{ClOO}+\mathrm{CH}_{3} \mathrm{O}, \mathrm{CH}_{3} \mathrm{OCl}+\mathrm{O}_{2}\right)$ & $3.3 \times 10^{-12} \exp [-115 / T]$ \\
\hline $\mathrm{Cl}+\mathrm{NO}_{2}+M \rightarrow \mathrm{ClNO}_{2}+M$ & see JPL-2010 \\
\hline $\mathrm{OH}+\mathrm{ClNO}_{2} \rightarrow \mathrm{HOCl}+\mathrm{NO}_{2}$ & $2.4 \times 10^{-12} \exp [-1250 / T]$ \\
\hline $\mathrm{CH}_{3} \mathrm{CCl}_{3}+\mathrm{OH} \rightarrow 3 \mathrm{Cl}+$ products & $1.64 \times 10^{-12} \exp [-1520 / T]$ \\
\hline $\mathrm{CH}_{3} \mathrm{CCl}_{3}+\mathrm{Cl} \rightarrow \mathrm{CH}_{2} \mathrm{CCl}_{3}+\mathrm{HCl}$ & $3.23 \times 10^{-12} \exp [-1770 / T]$ \\
\hline $\mathrm{CH}_{3} \mathrm{Cl}+\mathrm{OH} \rightarrow \mathrm{Cl}+$ products & $2.4 \times 10^{-12} \exp [-1250 / T]$ \\
\hline $\mathrm{CH}_{3} \mathrm{Cl}+\mathrm{Cl} \rightarrow \mathrm{CH}_{2} \mathrm{Cl}+\mathrm{HCl}$ & $2.17 \times 10^{-11} \exp [-1130 / T]$ \\
\hline $\mathrm{CCl}_{4}+\mathrm{O}\left({ }^{1} \mathrm{D}\right) \rightarrow$ products & $3.3 \times 10^{-10}$ \\
\hline $\mathrm{CFCl}_{3}+\mathrm{O}\left({ }^{1} \mathrm{D}\right) \rightarrow$ products & $2.3 \times 10^{-10}$ \\
\hline $\mathrm{CF}_{2} \mathrm{Cl}_{2}+\mathrm{O}\left({ }^{1} \mathrm{D}\right) \rightarrow$ products & $1.4 \times 10^{-10}$ \\
\hline $\mathrm{CClF}_{2} \mathrm{CCl}_{2} \mathrm{~F}+\mathrm{O}\left({ }^{1} \mathrm{D}\right) \rightarrow$ products & $2.0 \times 10^{-10}$ \\
\hline $\mathrm{CHClF}_{2}+\mathrm{O}\left({ }^{1} \mathrm{D}\right) \rightarrow$ products & $1.0 \times 10^{-10}$ \\
\hline $\mathrm{Br}+\mathrm{O}_{3} \rightarrow \mathrm{BrO}+\mathrm{O}_{2}$ & $1.6 \times 10^{-11} \exp [-780 / T]$ \\
\hline $\mathrm{Br}+\mathrm{HO}_{2} \rightarrow \mathrm{HBr}+\mathrm{O}_{2}$ & $4.8 \times 10^{-12} \exp [-310 / T]$ \\
\hline $\mathrm{Br}+\mathrm{H}_{2} \mathrm{O}_{2} \rightarrow \mathrm{HBr}+\mathrm{HO}_{2}$ & $1.0 \times 10^{-11} \exp [-3000 / T]$ \\
\hline $\mathrm{Br}+\mathrm{OClO} \rightarrow \mathrm{BrO}+\mathrm{ClO}$ & $2.6 \times 10^{-11} \exp [-1300 / T]$ \\
\hline $\mathrm{Br}+\mathrm{CH}_{2} \mathrm{O} \rightarrow \mathrm{HBr}+\mathrm{CHO}$ & $1.7 \times 10^{-11} \exp [-800 / T]$ \\
\hline $\mathrm{BrO}+\mathrm{O} \rightarrow \mathrm{Br}+\mathrm{O}_{2}$ & $1.9 \times 10^{-11} \exp [230 / T]$ \\
\hline $\mathrm{BrO}+\mathrm{OH} \rightarrow \mathrm{Br}+\mathrm{HO}_{2}$ & $1.666 \times 10^{-11} \exp [250 / T]$ \\
\hline $\mathrm{BrO}+\mathrm{OH} \rightarrow \mathrm{HBr}+\mathrm{O}_{2}$ & $3.4 \times 10^{-13} \exp [250 / T]$ \\
\hline $\mathrm{BrO}+\mathrm{HO}_{2} \rightarrow \mathrm{HOBr}+\mathrm{O}_{2}$ & $4.5 \times 10^{-12} \exp [460 / T]$ \\
\hline $\mathrm{BrO}+\mathrm{NO} \rightarrow \mathrm{Br}+\mathrm{NO}_{2}$ & $8.8 \times 10^{-12} \exp [260 / T]$ \\
\hline $\mathrm{BrO}+\mathrm{NO}_{2}+M \rightarrow \mathrm{BrONO}_{2}+M$ & see JPL-2010 \\
\hline $\mathrm{BrO}+\mathrm{ClO} \rightarrow \mathrm{Br}+\mathrm{OClO}$ & $9.5 \times 10^{-13} \exp [550 / T]$ \\
\hline $\mathrm{BrO}+\mathrm{ClO} \rightarrow \mathrm{Br}+\mathrm{ClOO}$ & $2.3 \times 10^{-12} \exp [260 / T]$ \\
\hline $\mathrm{BrO}+\mathrm{ClO} \rightarrow \mathrm{BrCl}+\mathrm{O}_{2}$ & $4.1 \times 10^{-13} \exp [290 / T]$ \\
\hline $\mathrm{HBr}+\mathrm{O}\left({ }^{1} \mathrm{D}\right) \rightarrow$ products $(\mathrm{Br}+\mathrm{OH}, \mathrm{HBr}+\mathrm{O}, \mathrm{H}+\mathrm{BrO})$ & $1.5 \times 10^{-10}$ \\
\hline $\mathrm{HBr}+\mathrm{O} \rightarrow \mathrm{OH}+\mathrm{Br}$ & $5.8 \times 10^{-12} \exp [-1500 / T]$ \\
\hline $\mathrm{HBr}+\mathrm{OH} \rightarrow \mathrm{Br}+\mathrm{H}_{2} \mathrm{O}$ & $5.5 \times 10^{-12} \exp [200 / T]$ \\
\hline $\mathrm{BrO}+\mathrm{BrO} \rightarrow 2 \mathrm{Br}+\mathrm{O}_{2}$ & $2.4 \times 10^{-12} \exp [40 / T]$ \\
\hline $\mathrm{BrO}+\mathrm{BrO} \rightarrow \mathrm{Br}_{2}+\mathrm{O}_{2}$ & $2.8 \times 10^{-14} \exp [860 / T]$ \\
\hline $\mathrm{BrO}+\mathrm{O}_{3} \rightarrow \mathrm{Br}+2 \mathrm{O}_{2}$ & $1.0 \times 10^{-12} \exp [-3225 / T]$ \\
\hline $\mathrm{BrONO}_{2}+\mathrm{O} \rightarrow \mathrm{BrO}+\mathrm{NO}_{3}$ & $1.9 \times 10^{-11} \exp [215 / T]$ \\
\hline $\mathrm{CHBr}_{3}+\mathrm{O}\left({ }^{1} \mathrm{D}\right) \rightarrow$ products & $6.6 \times 10^{-10}$ \\
\hline $\mathrm{CHBr}_{3}+\mathrm{OH} \rightarrow 3 \mathrm{Br}+$ products & $1.35 \times 10^{-12} \exp [-600 / T]$ \\
\hline
\end{tabular}


Table A2. Continued.

\begin{tabular}{|c|c|}
\hline (2) Gas-phase reactions & Reaction coefficients (reference) \\
\hline $\mathrm{CHBr}_{3}+\mathrm{Cl} \rightarrow \mathrm{CBr}_{3}+\mathrm{HCl}$ & $4.85 \times 10^{-12} \exp [-850 / T]$ \\
\hline $\mathrm{CH}_{3} \mathrm{Br}+\mathrm{O}\left({ }^{1} \mathrm{D}\right) \rightarrow$ products & $1.8 \times 10^{-10}$ \\
\hline $\mathrm{CH}_{3} \mathrm{Br}+\mathrm{OH} \rightarrow \mathrm{Br}+$ products & $2.35 \times 10^{-12} \exp [-1300 / T]$ \\
\hline $\mathrm{CH}_{3} \mathrm{Br}+\mathrm{Cl} \rightarrow \mathrm{CH}_{2} \mathrm{Br}+\mathrm{HCl}$ & $1.4 \times 10^{-11} \exp [-1030 / T]$ \\
\hline $\mathrm{CH}_{2} \mathrm{Br}_{2}+\mathrm{O}\left({ }^{1} \mathrm{D}\right) \rightarrow \mathrm{Br}+$ products & $2.7 \times 10^{-10}$ \\
\hline $\mathrm{CH}_{2} \mathrm{Br}_{2}+\mathrm{OH} \rightarrow \mathrm{CHBr}_{2}+\mathrm{H}_{2} \mathrm{O}$ & $2.0 \times 10^{-12} \exp [-840 / T]$ \\
\hline $\mathrm{CH}_{2} \mathrm{Br}_{2}+\mathrm{Cl} \rightarrow \mathrm{CHBr}_{2}+\mathrm{HCl}$ & $6.3 \times 10^{-12} \exp [-800 / T]$ \\
\hline $\mathrm{CF}_{2} \mathrm{ClBr}+\mathrm{O}\left({ }^{1} \mathrm{D}\right) \rightarrow$ products & $1.5 \times 10^{-10}$ \\
\hline $\mathrm{CF}_{3} \mathrm{Br}+\mathrm{O}\left({ }^{1} \mathrm{D}\right) \rightarrow$ products & $1.0 \times 10^{-10}$ \\
\hline (3) Heterogeneous reactions & Reaction coefficients (reference) \\
\hline $\mathrm{N}_{2} \mathrm{O}_{5}+\mathrm{H}_{2} \mathrm{O} \rightarrow 2 \mathrm{HNO}_{3}$ & see JPL-2010 and Akiyoshi (2007) \\
\hline $\mathrm{ClONO}_{2}+\mathrm{H}_{2} \mathrm{O} \rightarrow \mathrm{HOCl}+\mathrm{HNO}_{3}$ & see JPL-2010 and Akiyoshi (2007) \\
\hline $\mathrm{ClONO}_{2}+\mathrm{HCl} \rightarrow \mathrm{Cl}_{2}+\mathrm{HNO}_{3}$ & see JPL-2010 and Akiyoshi (2007) \\
\hline $\mathrm{HOCl}+\mathrm{HCl} \rightarrow \mathrm{Cl}_{2}+\mathrm{H}_{2} \mathrm{O}$ & see JPL-2010 and Akiyoshi (2007) \\
\hline $\mathrm{BrONO}_{2}+\mathrm{H}_{2} \mathrm{O} \rightarrow \mathrm{HOBr}+\mathrm{HNO}_{3}$ & see JPL-2010 and Akiyoshi (2007) \\
\hline $\mathrm{HOBr}+\mathrm{HCl} \rightarrow \mathrm{BrCl}+\mathrm{H}_{2} \mathrm{O}$ & see JPL-2010 and Akiyoshi (2007) \\
\hline $\mathrm{BrONO}_{2}+\mathrm{HCl} \rightarrow \mathrm{BrCl}+\mathrm{HNO}_{3}$ & see JPL-2010 and Akiyoshi (2007) \\
\hline $\mathrm{ClONO}_{2}+\mathrm{HBr} \rightarrow \mathrm{BrCl}+\mathrm{HNO}_{3}$ & see JPL-2010 and Akiyoshi (2007) \\
\hline $\mathrm{BrONO}_{2}+\mathrm{HBr} \rightarrow \mathrm{Br}_{2}+\mathrm{HNO}_{3}$ & see JPL-2010 and Akiyoshi (2007) \\
\hline $\mathrm{HOCl}+\mathrm{HBr} \rightarrow \mathrm{BrCl}+\mathrm{H}_{2} \mathrm{O}$ & see JPL-2010 and Akiyoshi (2007) \\
\hline $\mathrm{HOBr}+\mathrm{HBr} \rightarrow \mathrm{Br}_{2}+\mathrm{H}_{2} \mathrm{O}$ & see JPL-2010 and Akiyoshi (2007) \\
\hline $\mathrm{N}_{2} \mathrm{O}_{5}+\mathrm{HBr} \rightarrow \mathrm{BrNO}_{2}+\mathrm{HNO}_{3}$ & see JPL-2010 and Akiyoshi (2007) \\
\hline $\mathrm{N}_{2} \mathrm{O}_{5}+\mathrm{HCl} \rightarrow \mathrm{ClNO}_{2}+\mathrm{HNO}_{3}$ & see JPL-2010 and Akiyoshi (2007) \\
\hline
\end{tabular}

Total: 42 photolysis reactions, 140 gas-phase reactions, and 13 heterogeneous reactions. 


\section{Appendix B: Determined polar vortex edges}

The inner and outer edges of the polar vortex were determined as follows.

1. Equivalent latitudes (ELs) (McIntyre and Palmer, 1984; Butchart and Remsberg, 1986) were computed based on isentropic potential vorticity at 450 and $560 \mathrm{~K}$ isentropic surfaces for 18 and $22 \mathrm{~km}$, respectively, using the ERAInterim reanalysis data (Dee et al., 2011).

2. Inner and outer edges (at least $5^{\circ}$ apart from each other) of the polar vortex were defined by local maxima of the isentropic potential vorticity gradient with respect to equivalent latitude only when a tangential wind speed (i.e., mean horizontal wind speed along the isentropic potential vorticity contour; see Eq. 1 of Tomikawa and Sato, 2003) near the vortex edge exceeds a threshold value (i.e., $20 \mathrm{~m} \mathrm{~s}^{-1}$; see Nash et al., 1996, and Tomikawa et al., 2015).

3. Then, the polar region was divided into three regions - i.e., inside the polar vortex (inside of inner edge), in the boundary region of the polar vortex (between the inner and outer edges), and outside the polar vortex (outside of outer edge) - when there were two polar vortex edges. When there was only one edge, the polar region was divided into two regions: i.e., inside the polar vortex and outside the polar vortex.

Figures B1 and B2 show time-equivalent latitude sections of modified potential vorticity (MPV) and its gradient with respect to EL at 450 and $560 \mathrm{~K}$ isentropic potential temperature (PT) surfaces in 2007 and 2011, respectively. MPV is a scaled PV to remove its exponential increase with height (cf., Lait, 1994). The inner and outer edge(s) are plotted by black dots, while the ELs of Syowa Station on those days are plotted by red dots. It can be seen that inner edges were first formed at an EL of around $70^{\circ}$ in April, and outer edges started to form at an EL of around $55^{\circ}$ in July-August, forming the boundary region. Then, those two edges converge into one edge at an EL of around $60^{\circ}$ in November. Finally, the polar vortex edge disappeared in December. Syowa Station was mostly located inside the polar vortex, but it was sometimes located at the boundary region or outside the polar vortex, depending on different PT levels.

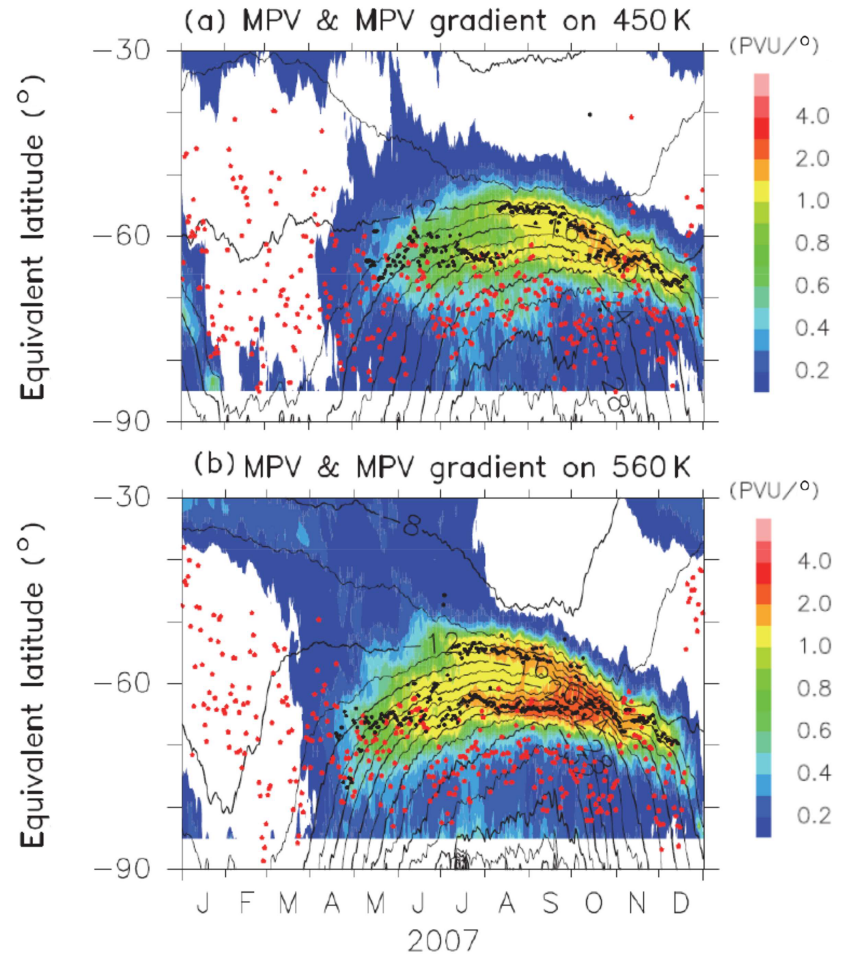

Figure B1. Time-equivalent latitude sections of MPV (contours) and its gradient with respect to EL (colors) at (a) $450 \mathrm{~K}$ and (b) $560 \mathrm{~K}$ isentropic PT surfaces in 2007. Black dots represent the inner and outer edge(s) of the polar vortex. Red dots represent the EL of Syowa Station on each day.

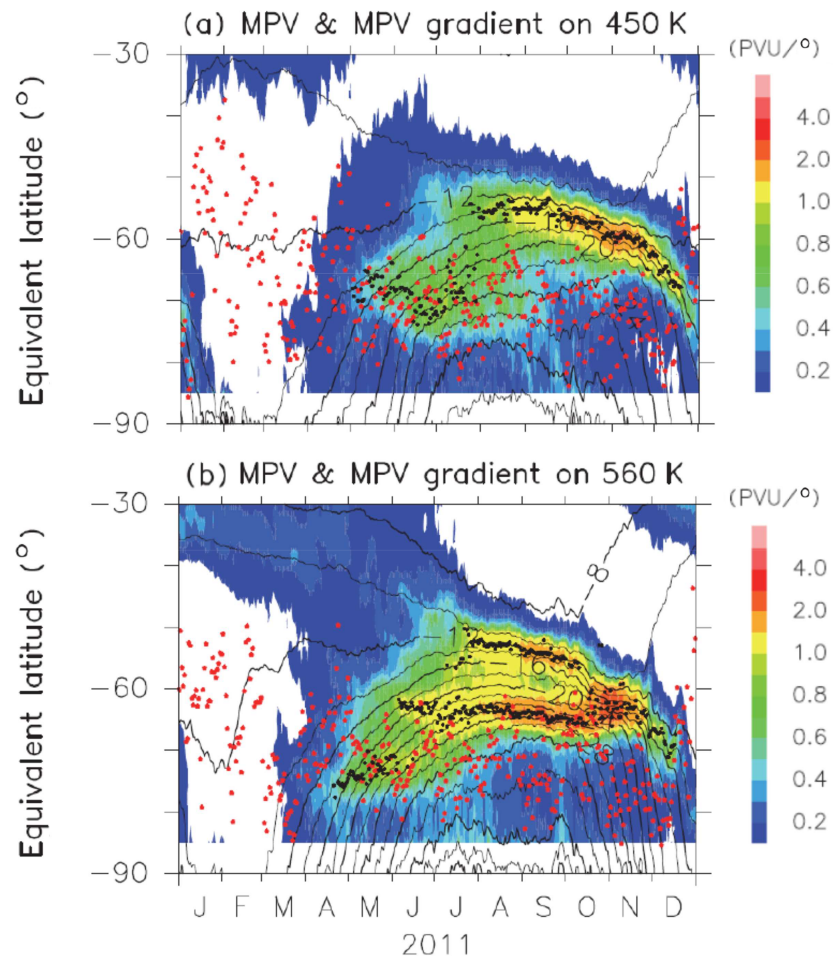

Figure B2. Same as Fig. B1 but for the year in 2011. 
Appendix $\mathrm{C}$ : $\mathrm{HCl}$ null cycles $\left(\mathrm{C}_{1}\right.$ and $\left.\mathrm{C}_{2}\right)$ and $\mathrm{HCl}$ destruction cycles $\left(\mathrm{C}_{3}\right.$ and $\left.\mathrm{C}_{4}\right)$

In Müller et al. (2018), new chemical cycles $C_{1}$ and $C_{2}$ were proposed to maintain high levels of active chlorine in the Antarctic spring, referred to as $\mathrm{HCl}$ null cycles, as follows:

$\mathrm{CH}_{4}+\mathrm{Cl} \rightarrow \mathrm{HCl}+\mathrm{CH}_{3}$

$\mathrm{CH}_{3}+\mathrm{O}_{2}+M \rightarrow \mathrm{CH}_{3} \mathrm{O}_{2}+M$,

$\mathrm{CH}_{3} \mathrm{O}_{2}+\mathrm{ClO} \rightarrow \mathrm{CH}_{3} \mathrm{O}+\mathrm{Cl}+\mathrm{O}_{2}$,

$\mathrm{CH}_{3} \mathrm{O}+\mathrm{O}_{2} \rightarrow \mathrm{HO}_{2}+\mathrm{CH}_{2} \mathrm{O}$,

$\mathrm{ClO}+\mathrm{HO}_{2} \rightarrow \mathrm{HOCl}+\mathrm{O}_{2}$,

$\mathrm{HOCl}+\mathrm{HCl} \rightarrow \mathrm{Cl}_{2}+\mathrm{H}_{2} \mathrm{O}$,

$\mathrm{Cl}_{2}+h v \rightarrow 2 \mathrm{Cl}$,

$\mathrm{Cl}+\mathrm{O}_{3} \rightarrow \mathrm{ClO}+\mathrm{O}_{2} \quad(2 \times)$,

$\operatorname{Net}\left(\mathrm{C}_{1}\right) \mathrm{CH}_{4}+2 \mathrm{O}_{2} \rightarrow \mathrm{CH}_{2} \mathrm{O}+\mathrm{H}_{2} \mathrm{O}+2 \mathrm{O}_{2}$,

$\mathrm{CH}_{2} \mathrm{O}+\mathrm{Cl} \rightarrow \mathrm{HCl}+\mathrm{CHO}$,

$\mathrm{CHO}+\mathrm{O}_{2} \rightarrow \mathrm{CO}+\mathrm{HO}_{2}$,

$\mathrm{ClO}+\mathrm{HO}_{2} \rightarrow \mathrm{HOCl}+\mathrm{O}_{2}$,

$\mathrm{HOCl}+\mathrm{HCl} \rightarrow \mathrm{Cl}_{2}+\mathrm{H}_{2} \mathrm{O}$,

$\mathrm{Cl}_{2}+h v \rightarrow 2 \mathrm{Cl}$,

$\mathrm{Cl}+\mathrm{O}_{3} \rightarrow \mathrm{ClO}+\mathrm{O}_{2}$,

$\mathrm{Net}\left(\mathrm{C}_{2}\right) \mathrm{CH}_{2} \mathrm{O}+\mathrm{O}_{3} \rightarrow \mathrm{CO}+\mathrm{H}_{2} \mathrm{O}+\mathrm{O}_{2}$,
Also, other chemical cycles which are responsible for the decline of $\mathrm{HCl}$ during Antarctic August and September, referred to as $\mathrm{HCl}$ destruction cycles, are also proposed by Müller et al. (2018) as follows:

$\mathrm{CH}_{2} \mathrm{O}+h v \rightarrow \mathrm{CHO}+\mathrm{H}, \quad$ (R29)

$\mathrm{H}+\mathrm{O}_{2}+M \rightarrow \mathrm{HO}_{2}+M$,

$\mathrm{CHO}+\mathrm{O}_{2} \rightarrow \mathrm{CO}+\mathrm{HO}_{2}$,

$\mathrm{ClO}+\mathrm{HO}_{2} \rightarrow \mathrm{HOCl}+\mathrm{O}_{2} \quad(2 \times)$,

(R24)

$\mathrm{HOCl}+\mathrm{HCl} \rightarrow \mathrm{Cl}_{2}+\mathrm{H}_{2} \mathrm{O} \quad(2 \times)$,

$\mathrm{Cl}_{2}+h v \rightarrow 2 \mathrm{Cl}(2 \times)$,

$\mathrm{Cl}+\mathrm{O}_{3} \rightarrow \mathrm{ClO}+\mathrm{O}_{2} \quad(4 \times)$,

$\operatorname{Net}\left(\mathrm{C}_{3}\right) \mathrm{CH}_{2} \mathrm{O}+2 \mathrm{HCl}+4 \mathrm{O}_{3}$

$$
\rightarrow \mathrm{CO}+2 \mathrm{ClO}+2 \mathrm{H}_{2} \mathrm{O}+4 \mathrm{O}_{2} \text {, }
$$

$\mathrm{O}_{3}+h v \rightarrow \mathrm{O}\left({ }^{1} \mathrm{D}\right)+\mathrm{O}_{2}$,

$\mathrm{O}\left({ }^{1} \mathrm{D}\right)+\mathrm{H}_{2} \mathrm{O} \rightarrow 2 \mathrm{OH}$,

$\mathrm{OH}+\mathrm{O}_{3} \rightarrow \mathrm{HO}_{2}+\mathrm{O}_{2} \quad(2 \times)$,

$\mathrm{ClO}+\mathrm{HO}_{2} \rightarrow \mathrm{HOCl}+\mathrm{O}_{2} \quad(2 \times)$,

(R24)
$\mathrm{Cl}_{2}+h v \rightarrow 2 \mathrm{Cl}(2 \times)$,

$\mathrm{Cl}+\mathrm{O}_{3} \rightarrow \mathrm{ClO}+\mathrm{O}_{2} \quad(4 \times)$, 
Data availability. The FTIR data presented here can be obtained from the Global Environmental Database at the National Institute for Environmental Studies in electronic form (HDF files) from the following DOIs:

- https://doi.org/10.17595/20190911.001 (FTIR data for 2007; Nakajima, 2019a),

- https://doi.org/10.17595/20190911.002 (FTIR data for 2011; Nakajima, 2019b).

The MIROC3.2 CCM outputs are from the REF-C1SD simulation data from the CCMI, which are stored at the CCMI site of the Centre for Environmental Data Analysis at the National Centre for Earth Observation at http://data.ceda.ac.uk/badc/wcrp-ccmi/data/ CCMI-1/output/NIES/CCSRNIES-MIROC3.2 (last access: 21 January 2020).

The MLS data were taken from NASA's Earthdata page at the Goddard Space Flight Center at the following site: https: //disc.gsfc.nasa.gov/datasets?page=1\&keywords=AURAMLS (last access: 21 January 2020; Earth Data, 2020).

The MIPAS data were taken from the Institute of Meteorology and Climate Research at the Karlsruhe Institute of Technology at the following site: http://www.imk-asf.kit.edu/english/308.php (last access: 21 January 2020).

The CALIOP data were taken from NASA's Langley Research Center data center at the following site: https://www-calipso.larc.nasa.gov/resources/calipso_users_guide/ data_summaries/psc/index.php (last access: 21 January 2020; National Aeronautics and Space Administration, 2020).

Author contributions. HN, IM, YN, and MT conceived and worked on the current research project. HN, KS, and TK made FTIR observations at Syowa Station in 2007 and 2011. HN, YN, KS, and NBJ conducted the SFIT2 retrievals. HA conducted MIROC3.2 CCM simulations and ED analyzed them. YT performed the polar vortex categorization calculation. HN, IM, YN, HA, YT, and NBJ contributed to the interpretation of the results and wrote the paper.

Competing interests. The authors declare that they have no conflict of interest.

Acknowledgements. We acknowledge all the members of the 48th Japanese Antarctic Research Expedition (JARE-48) and JARE-52 for their support in making the FTIR observation at Syowa Station. The data provision of Aura MLS, Envisat MIPAS, and CALIPSO CALIOP is much appreciated. We thank the Japan Meteorological Agency for providing the ozonesonde and rawinsonde data at Syowa Station. Thanks are due to Yosuke Yamashita for performing the CCM run. The model computations were performed on NECSX9/A(ECO) and NEC SX-ACE computers at the CGER, NIES. We thank Takafumi Sugita for useful discussion and comments. We also thank the three anonymous referees for their useful comments, which significantly improved the contents of this paper.

Financial support. The model computations in this research has been supported by the Ministry of the Environment, Japan (grant no. 2-1303), and the Environment Restoration and Conservation Agency, Japan (grant no. 2-1709).

Review statement. This paper was edited by Farahnaz Khosrawi and reviewed by three anonymous referees.

\section{References}

Akiyoshi, H.: Modeling of the heterogeneous reaction processes on the polar stratospheric clouds in chemical transport models and the effects on the Arctic ozone layer through bromine species, Earozoru Kenkyu, 22, 196-203, 2007 (in Japanese).

Akiyoshi, H., Zhou, L. B., Yamashita, Y., Sakamoto, K., Yoshiki, M., Nagashima, T., Takahashi, M., Kurokawa, J., Takigawa, M., and Imamura, T.: A CCM simulation of the breakup of the Antarctic polar vortex in the years 1980-2004 under the CCMVal scenarios, J. Geophys. Res., 114, D03103, https://doi.org/10.1029/2007JD009261, 2009.

Akiyoshi, H., Yamashita, Y., Sakamoto, K., Zhou, L. B., and Imamura, T.: Recovery of stratospheric ozone in calculations by the Center for Climate System Research/National Institute for Environmental Studies chemistry-climate model under the CCMValREF2 scenario and a no-climate-change run, J. Geophys. Res., 115, D19301, https://doi.org/10.1029/2009JD012683, 2010.

Akiyoshi, H., Nakamura, T., Miyasaka, T., Shiotani, M., and Suzuki, M.: A nudged chemistry-climate model simulation of chemical constituent distribution at northern high-latitude stratosphere observed by SMILES and MLS during the 2009/2010 stratospheric sudden warming, J. Geophys. Res.-Atmos., 121, 1361-1380, https://doi.org/10.1002/2015JD023334, 2016.

Anderson, J., Russell III, J. M., Solomon, S., and Deaver, L. E.: Halogen Occultation Experiment confirmation of stratospheric chlorine decreases in accordance with the Montreal Protocol, J. Geophys. Res., 105, 4483-4490, https://doi.org/10.1029/1999JD901075, 2000.

Anderson, J. G., Brune, W. H., and Proffitt, M. H.: Ozone destruction by chlorine radicals within the Antarctic vortex: The spatial and temporal evolution of $\mathrm{ClO}-\mathrm{O}_{3}$ anticorrelation based on in situ ER-2 data, J. Geophys. Res., 94, 11465-11479, 1989.

Bonne, G. P., Stimpfle, R. M., Cohen, R. C., Voss, P. B., Perkins, K. K., Anderson, J. G., Salawitch, R. J., Elkins, J. W., Dutton, G. S., Jucks, K. W., and Toon, G. C.: An examination of the inorganic chlorine budget in the lower stratosphere, J. Geophys. Res., 105, 1957-1971, 2000.

Brasseur, G. and Solomon, S.: Aeronomy of the middle atmosphere, D. Reidel Pub. Co., 452 pp., 1986.

Butchart, N. and Remsberg, E. E.: The area of the stratospheric polar vortex as a diagnostic for tracer transport on an isentropic surface, J. Atmos. Sci., 43, 1319-1339, 1986.

Canty, T. P., Salawitch, R. J., and Wilmouth, D. M.: The kinetics of the ClOOCl catalytic cycle, J. Geophys. Res., 121, 13768-13783, https://doi.org/10.1002/2016JD025710, 2016.

Chubachi, S.: Preliminary result of ozone observation at Syowa Station from February 1982 to January 1983, Mem. Natl. Inst. Polar Res., 34, 13-19, 1984. 
Connor, B., Parrish, A., Tsou, J., and McCormick, M.: Error analysis for the ground-based microwave ozone measurements during STOIC, J. Geophys. Res., 100, 9283-9291, 1995.

Dee, D. P., Uppala, S. M., Simmons, A. J., Berrisford, P., Poli, P., Kobayashi, S., Andrae, U., Balmaseda, M. A., Balsamo, G., Bauer, P., Bechtold, P., Beljaars, A. C. M., van de Berg, L., Bidlot, J., Bormann, N., Delsol, C., Dragani, R., Fuentes, M., Geer, A. J., Haimberger, L., Healy, S. B., Hersbach, H., Hólm, E. V., Isaksen, L., Kållberg, P., Köhler, M., Matricardi, M., McNally, A. P., Monge-Sanz, B. M., Morcrette, J.-J., Park, B.-K., Peubey, C., de Rosnay, P., Tavolato, C., Thépaut, J.-N., and Vitart, F.: The ERA-Interim reanalysis: configuration and performance of the data assimilation system, Q. J. Roy. Meteor. Soc., 137, 553-597, https://doi.org/10.1002/qj.828, 2011.

de Laat, A. T. J., van Weele, M., and van der A, R. J.: Onset of stratospheric ozone recovery in the Antarctic ozone hole in assimilated daily total ozone columns, J. Geophys. Res., 122, 11880-11899, https://doi.org/10.1002/2016JD025723, 2017.

de Zafra, R. L., Jaramillo, M., Barrett, J., Emmons, L. K., Solomon, P. M., and Parrish, A.: New observations of a large concentration of $\mathrm{ClO}$ in the springtime lower stratosphere over Antarctica and its implications for ozone-depleting chemistry, J. Geophys. Res., 94, 11423-11428, 1989.

Douglass, A. R., Schoeberl, M. R., Stolarski, R. S., Waters, J. W., Russell III, J. M., Roche, A. E., and Massie, S. T.: Interhemispheric differences in springtime production of $\mathrm{HCl}$ and $\mathrm{ClONO}_{2}$ in the polar vortices, J. Geophys. Res., 100, 13967-13978, 1995.

Drdla, K. and Müller, R.: Temperature thresholds for chlorine activation and ozone loss in the polar stratosphere, Ann. Geophys., 30, 1055-1073, https://doi.org/10.5194/angeo-30-10552012, 2012.

Dufour, G., Nassar, R., Boone, C. D., Skelton, R., Walker, K. A., Bernath, P. F., Rinsland, C. P., Semeniuk, K., Jin, J. J., McConnell, J. C., and Manney, G. L.: Partitioning between the inorganic chlorine reservoirs $\mathrm{HCl}$ and $\mathrm{ClONO}_{2}$ during the Arctic winter 2005 from the ACE-FTS, Atmos. Chem. Phys., 6, 23552366, https://doi.org/10.5194/acp-6-2355-2006, 2006.

Earth Data: AURA MLS Data collections, available at: https://disc. gsfc.nasa.gov/datasets?page=1\&keywords=AURAMLS, last access: 21 January 2020.

Farman, J. C., Gardiner, B. G., and Shanklin, J. D.: Large losses of total ozone in Antarctica reveal seasonal $\mathrm{ClO}_{x} / \mathrm{NO}_{x}$ interaction, Nature, 315, 207-210, 1985.

Farmer, C. B., Toon, G. C., Schaper, P. W., Blavier, J.-F., and Lowes, L. L.: Stratospheic trace gases in the spring 1986 Antarctic atmosphere, Nature, 329, 126-130, 1987.

Fischer, H. and Oelhaf, H.: Remote sensing of vertical profiles of atmospheric trace constituents with MIPAS limb-emission spectrometers, Appl. Optics, 35, 2787-2796, 1996.

Fischer, H., Birk, M., Blom, C., Carli, B., Carlotti, M., von Clarmann, T., Delbouille, L., Dudhia, A., Ehhalt, D., Endemann, M., Flaud, J. M., Gessner, R., Kleinert, A., Koopman, R., Langen, J., López-Puertas, M., Mosner, P., Nett, H., Oelhaf, H., Perron, G., Remedios, J., Ridolfi, M., Stiller, G., and Zander, R.: MIPAS: an instrument for atmospheric and climate research, Atmos. Chem. Phys., 8, 2151-2188, https://doi.org/10.5194/acp-8-21512008, 2008.

Froidevaux, L., Livesey, N. J., Read, W. G., Jiang, Y. B., Jimenez, C., Filipiak, M. J., Schwartz, M. J., Santee, M. L., Pumphrey, H.
C., Jiang, J. H., Wu, D. L., Manney, G. L., Drouin, B. J., Waters, J. W., Fetzer, E. J., Bernath, P. F., Boone, C. D., Walker, K. A., Jucks, K. W., Toon, G. C., Margitan, J. J., Sen, B., Webster, C. R., Christensen, L. E., Elkins, J. W., Atlas, E., Lueb, R. A., and Hendershot, R.: Early validation analyses of atmospheric profiles from EOS MLS on the Aura satellite, IEEE T. Geosci. Remote Sens., 44, 1106-1121, 2006.

Froidevaux, L., Jiang, Y. B., Lambert, A., Livesey, N. J., Read, W. G., Waters, J. W., Browell, E. V., Hair, J. W., Avery, M. A., McGee, T. J., Twigg, L. W., Sumnicht, G. K., Jucks, K. W., Margitan, J. J., Sen, B., Stachnik, R. A., Toon, G. C., Bernath, P F., Boone, C. D., Walker, K. A., Filipiak, M. J., Harwood, R. S., Fuller, R. A., Manney, G. L., Schwartz, M. J., Daffer, W. H., Drouin, B. J., Cofield, R. E., Cuddy, D. T., Jarnot, R. F., Knosp, B. W., Perun, V. S., Snyder, W. V., Stek, P. C., Thurstans, R. P., and Wagner, P. A.: Validation of Aura Microwave Limb Sounder stratospheric ozone measurements, J. Geophys. Res., 113, D15S20, https://doi.org/10.1029/2007JD008771, 2008.

Gallery, W. O., Kneizys, F. S., and Clough, S. A.: Air mass computer program for atmospheric transmittance/radiance calculation: FSCATM, Environmental Research Paper ERP-828/AFGLTR-83-0065, Air Force Geophysical Laboratory, Bedford, MA, USA, 1983.

Goldman, A., Fernald, F. G., Murcray, F. J., Murcray, F. H., and Murcray, D. G.: Spectral least squares quantification of several atmospheric gases from high resolution infrared solar spectra obtained at the South Pole, J. Quant. Spectrosc. Ra., 29, 189-204, 1983.

Goldman, A., Murcray, F. J., Murcray, F. H., and Murcray, D. G.: Quantification of $\mathrm{HCl}$ from high resolution infrared solar spectra obtained at the South Pole in December 1986, Geophys. Res. Lett., 14, 622-623, 1987.

Grooß, J.-U., Pierce, R. B., Crutzen, P. J., Grose, W. L., and Russell III, J. M.: Reformation of chlorine reservoirs in southern hemisphere polar spring, J. Geophys., Res., 102, 13141-13152, https://doi.org/10.1029/96JD03505, 1997.

Grooß, J.-U., Brautzsch, K., Pommrich, R., Solomon, S., and Müller, R.: Stratospheric ozone chemistry in the Antarctic: what determines the lowest ozone values reached and their recovery?, Atmos. Chem. Phys., 11, 12217-12226, https://doi.org/10.5194/acp-11-12217-2011, 2011.

Grooß, J.-U., Müller, R., Spang, R., Tritscher, I., Wegner, T., Chipperfield, M. P., Feng, W., Kinnison, D. E., and Madronich, S.: On the discrepancy of $\mathrm{HCl}$ processing in the core of the wintertime polar vortices, Atmos. Chem. Phys., 18, 8647-8666, https://doi.org/10.5194/acp-18-8647-2018, 2018

Hase, F, Hannigan, J. W., Co1ey, M. T., Goldman, A., Höpfner, M., Jones, N. B., Rinsland, C. P., and Wood, S. W.: Intercomparison of retrieval codes used for the analysis of high-resolution, ground-based FTIR measurements, J. Quant. Spectrosc. Ra., 87, 25-52, 2004.

Hayashida, S., Sugita, T., Ikeda, N., Toda, Y., and Irie, H.: Temporal evolution of $\mathrm{ClONO}_{2}$ observed with Improved Limb Atmospheric Spectrometer (ILAS) during Arctic late winter and early spring in 1997, J. Geophys. Res., 112, D14311, https://doi.org/10.1029/2006JD008108, 2007.

Höpfner, M., von Clarmann, T., Fischer, H., Glatthor, N., Grabowski, U., Kellmann, S., Kiefer, M., Linden, A., Mengistu Tsidu, G., Milz, M., Steck, T., Stiller, G. P., Wang, D. Y., and 
Funke, B.: First spaceborne observations of Antarctic stratospheric $\mathrm{ClONO}_{2}$ recovery: Austral spring 2002, J. Geophys. Res., 109, D11308, https://doi.org/10.1029/2004JD004609, 2004.

Höpfner, M., von Clarmann, T., Fischer, H., Funke, B., Glatthor, N., Grabowski, U., Kellmann, S., Kiefer, M., Linden, A., Milz, M., Steck, T., Stiller, G. P., Bernath, P., Blom, C. E., Blumenstock, Th., Boone, C., Chance, K., Coffey, M. T., Friedl-Vallon, F., Griffith, D., Hannigan, J. W., Hase, F., Jones, N., Jucks, K. W., Keim, C., Kleinert, A., Kouker, W., Liu, G. Y., Mahieu, E., Mellqvist, J., Mikuteit, S., Notholt, J., Oelhaf, H., Piesch, C., Reddmann, T., Ruhnke, R., Schneider, M., Strandberg, A., Toon, G., Walker, K. A., Warneke, T., Wetzel, G., Wood, S., and Zander, R.: Validation of MIPAS $\mathrm{ClONO}_{2}$ measurements, Atmos. Chem. Phys., 7, 257-281, https://doi.org/10.5194/acp-7-257-2007, 2007.

Jaeglé, L., Webster, C. R., May, R. D., Scott, D. C., Stimpfle, R. M., Kohn, D. W., Wennberg, P. O., Hanisco, T. F., Cohen, R. C., Proffitt, M. H., Kelly, K. K., Elkins, J., Baumgardner, D., Dye, J. E., Wilson, J. C., Pueschel, R. F., Chan, K. R., Salawitch, R. J., Tuck, A. F., Hovde, S. J., and Yung, Y. L.: Evolution and stoichiometry of heterogeneous processing in the Antarctic stratosphere, J. Geophys. Res., 102, 13235-13253, 1997.

Ko, M. K. W., Rodriguez, J. M., Sze, N. D., Proffitt, M. H., Starr, W. L., Krueger, A., Browell, E. V., and McCormick, M. P.: Implications of AAOE observations for proposed chemical explanations of the seasonal and interannual behavior of Antarctic ozone, J. Geophys. Res., 94, 16705-16715, 1989.

Komhyr, W. D.: Operations handbook - Ozone measurements to $40 \mathrm{~km}$ altitude with model $4 \mathrm{~A}$-ECC-ozone sondes, NOAA Techn. Memorandum ERL-ARL-149, National Oceanic and Atmospheric Administration, Air Resources Lab., Silver Spring, MD, USA, 1986.

Kreher, K., Keys, J. G., Johnston, P. V., Platt, U., and Liu, X.: Ground-based measurements of $\mathrm{OClO}$ and $\mathrm{HCl}$ in austral spring 1993 at Arrival Heights Antarctica, Geophys. Res. Lett., 23, 1545-1548, 1996.

Kurokawa, J., Akiyoshi, H., Nagashima, T., Nakane, H., Masunaga, H., Nakajima, T., and Takahashi, M.: Effects of atmospheric sphericity on the stratospheric chemistry and dynamics over Antarctica, J. Geophys. Res., 110, D21305, https://doi.org/10.1029/2005JD005798, 2005.

Kuttippurath, J., Goutail, F., Pommereau, J.-P., Lefèvre, F., Roscoe, H. K., Pazmiño, A., Feng, W., Chipperfield, M. P., and GodinBeekmann, S.: Estimation of Antarctic ozone loss from groundbased total column measurements, Atmos. Chem. Phys., 10, 6569-6581, https://doi.org/10.5194/acp-10-6569-2010, 2010.

Lait, L. R.: An alternative form for potential vorticity, J. Atmos. Sci., 51, 1754-1759, 1994.

Lee, A. M., Roscoe, H. K., Jones, A. E., Haynes, P. H., Shuckburgh, E. F., Morrey, M. W., and Pumphrey, H. C.: The impact of the mixing properties within the Antarctic stratospheric vortex on ozone loss in spring, J. Geophys. Res., 106, 3203-3211, https://doi.org/10.1029/2000JD900398, 2001.

Lin, S.-J. and Rood, R. B.: Multidimensional flux-form semiLagrangian transport schemes, Mon. Weather Rev., 124, 20462070, 1996.

Livesey, N., Van Snyder, W., Read, W., and Wagner, P.: Retrieval algorithms for the EOS Microwave Limb Sounder
(MLS), IEEE T. Geosci. Remote Sens., 44, 1144-1155, https://doi.org/10.1109/TGRS.2006.872327, 2006.

Livesey, N. J., Read, W. G., Froidevaux, L., Lambert, A., Manney, G. L., Pumphrey, H. C., Santee, M. L., Schwartz, M. J., Wang, S., Cofield, R. E., Cuddy, D. T., Fuller, R. A., Jarnot, R. F., Jiang, J. H., Brian W. Knosp, Stek, P. C., Wagner, P. A., and Wu, D. L.: Version 3.3 and 3.4 Level 2 data quality and description document, Jet Propul. Lab., Tech. Rep. JPL D-33509, Pasadena, CA, USA, available at: http://mls.jpl.nasa.gov (last access: 21 January 2020), 2013.

Livesey, N. J., Read, W. G., Wagner, P. A., Froidevaux, L., Lambert, A., Manney, G. L., Millán Valle, L. F., Pumphrey, H. C. Santee, M. L., Schwartz, M. J., Wang, S., Fuller, R. A., Jarnot, R. F., Knosp, B. W., Martinez, E., and Lay, R. R.: Version 4.2x Level 2 data quality and description document, Jet Propul. Lab., Tech. Rep. JPL D-33509 Rev. D, Pasadena, CA, USA, available at: http://mls.jpl.nasa.gov (last access: 21 January 2020), 2018.

Manney, G. L., Santee, M. L, Rex, M., Livesey, N. J., Pitts, M. C., Veefkind, P., Nash, E. R., Wohltmann, I., Lehmann, R., Froidevaux, L., Poole, L. R., Schoeberl, M. R., Haffner, D. P., Davies, J., Dorokhov, V., Gernandt, H., Johnson, B., Kivi, R., Kyrö, E., Larsen, N., Levelt, P. F., Makshtas, A., McElroy, C. T., Nakajima, H., Parrondo, M. C., Tarasick, D. W., von der Gathen, P., Walker, K. A., and Zinoviev, N. S.: Unprecedented Arctic ozone loss in 2011, Nature, 478, 469-475, https://doi.org/10.1038/nature10556, 2011.

McIntyre, M. E. and Palmer, T. N.: The "surf zone" in the stratosphere, J. Atmos. Terr. Phys., 46, 825-849, 1984.

Mellqvist, J., Galle, B., Blumenstock, T., Hase, F., Yashcov, D., Notholt, J., Sen, B., Blavier, J.-F., Toon, G. C., and Chipperfield, M. P.: Ground-based FTIR observations of chlorine activation and ozone depletion inside the Arctic vortex during the winter of 1999/2000, J. Geophys. Res., 107, 8263, https://doi.org/10.1029/2001JD001080, 2002.

Michelsen, H. A., Webster, C. R., Manney, G. L., Scott, D. C., Margitan, J. J., May, R. D., Irion, F. W., Gunson, M. R., Russell III, J. M., and Spivakovssky, C. M.: Maintenance of high $\mathrm{HCl} / \mathrm{Cl}_{y}$ and $\mathrm{NO}_{x} / \mathrm{NO}_{y}$ in the Antarctic vortex: A chemical signature of confinement during spring, J. Geophys. Res., 104, 26419-26436, 1999.

Morgenstern, O., Hegglin, M. I., Rozanov, E., O’Connor, F. M., Abraham, N. L., Akiyoshi, H., Archibald, A. T., Bekki, S., Butchart, N., Chipperfield, M. P., Deushi, M., Dhomse, S. S., Garcia, R. R., Hardiman, S. C., Horowitz, L. W., Jöckel, P., Josse, B., Kinnison, D., Lin, M., Mancini, E., Manyin, M. E., Marchand, M., Marécal, V., Michou, M., Oman, L. D., Pitari, G., Plummer, D. A., Revell, L. E., Saint-Martin, D., Schofield, R., Stenke, A., Stone, K., Sudo, K., Tanaka, T. Y., Tilmes, S., Yamashita, Y., Yoshida, K., and Zeng, G.: Review of the global models used within phase 1 of the Chemistry-Climate Model Initiative (CCMI), Geosci. Model Dev., 10, 639-671, https://doi.org/10.5194/gmd-10-639-2017, 2017.

Müller, R., Peter, T., Crutzen, P. J., Oelhaf, H., Adrian, G. P., v. Clarmann, T., Wegner, A., Schmidt, U., and Lary, D.: Chlorine chemistry and the potential for ozone depletion in the Arctic stratosphere in the winter of 1991/92, Geophys. Res. Lett., 21, 1427-1430, 1994.

Müller, R., Crutzen, P. J., Grooß, J.-U., Brühl, C., Russell III, J. M., and Tuck, A. F.: Chlorine activation and ozone depletion in the 
Arctic vortex: Observations by the Halogen Occultation Experiment on the Upper Atmosphere Research Satellite, J. Geophys. Res., 101, 12531-12554, 1996.

Müller, R., Grooß, J.-U., Zafar, A. M., Robrecht, S., and Lehmann, R.: The maintenance of elevated active chlorine levels in the Antarctic lower stratosphere through $\mathrm{HCl}$ null cycles, Atmos. Chem. Phys., 18, 2985-2997, https://doi.org/10.5194/acp-182985-2018, 2018.

Murcray, F. J., Murcray, F. H., Goldman, A., and Murcray, D. G.: Infrared measurements of several nitrogen species above the South Pole in December 1980 and November-December 1986, J. Geophys. Res., 92, 13373-13376, 1987.

Murcray, F. J., Goldman, A., Blatherwick, R., Matthews, A., and Jones, N. B.: $\mathrm{HNO}_{3}$ and $\mathrm{HCl}$ amounts over McMurdo during the spring of 1987, J. Geophys. Res., 94, 16615-16618, 1989.

Nakajima, H.: Preface to special section on ILAS-II: The Improved Limb Atmospheric Spectrometer II, J. Geophys. Res., 111, D20S90, https://doi.org/10.1029/2006JD007412, 2006.

Nakajima, H.: Atmospheric Profiles and Total Columns of $\mathrm{O}_{3}, \mathrm{HNO}_{3}$, and $\mathrm{HCl}$ Measured by Fourier Transform Infrared Spetrometer (FTIR) at Antarctic Syowa Station in 2007, Center for Global Environmental Research, NIES, https://doi.org/10.17595/20190911.001, 2019a.

Nakajima, H.: Atmospheric Profiles and Total Columns of $\mathrm{O}_{3}, \mathrm{HNO}_{3}$, and $\mathrm{HCl}$ Measured by Fourier Transform Infrared Spetrometer (FTIR) at Antarctic Syowa Station in 2011, Center for Global Environmental Research, NIES, https://doi.org/10.17595/20190911.002, 2019b.

Nakajima, H., Sugita, T., Yokota, T., Ishigaki, T., Mogi, Y., Araki, N., Waragai, K., Kimura, N., Iwazawa, T., Kuze, A., Tanii, J., Kawasaki, H., Horikawa, M., Togami, T., Uemura, N., Kobayashi, H., and Sasano, Y.: Characteristics and performance of the Improved Limb Atmospheric Spectrometer-II (ILAS-II) on board the ADEOS-II satellite, J. Geophys. Res., 111, D11S01, https://doi.org/10.1029/2005JD006334, 2006.

Nakajima, H., Wohltmann, I., Wegner, T., Takeda, M., Pitts, M. C., Poole, L. R., Lehmann, R., Santee, M. L., and Rex, M.: Polar stratospheric cloud evolution and chlorine activation measured by CALIPSO and MLS, and modeled by ATLAS, Atmos. Chem. Phys., 16, 3311-3325, https://doi.org/10.5194/acp16-3311-2016, 2016.

Nash, E. R., Newman, P. A., Rosenfield, J. E., and Schoeberl, M. R.: An objective determination of the polar vortex using Ertel's potential vorticity, J. Geophys. Res., 101, 9471-9478, 1996.

National Aeronautics and Space Administration: CALIPSO: Data User's Guide - Data Product Descriptions - Lidar Level 2 Polar Stratospheric Cloud (PSC) Version 1.x Product Ensemble, available at: https://www-calipso.larc.nasa.gov/resources/ calipso_users_guide/data_summaries/psc/index.php, last access: 21 January 2020.

Newman, P. A., Daniel, J. S., Waugh, D. W., and Nash, E. R.: A new formulation of equivalent effective stratospheric chlorine (EESC), Atmos. Chem. Phys., 7, 4537-4552, https://doi.org/10.5194/acp-7-4537-2007, 2007.

Norton, R. and Rinsland, C.: ATMOS data processing and science analysis methods, Appl. Optics, 30, 389-400, 1991.

Oelhaf, H., v. Clarmann, T., Fischer, H., Friedl-Vallon, F., Fritzsche, C., Linden, A., Piesch, C., Seefeldner, M., and Völker, W.: Stratospheric $\mathrm{ClONO}_{2}$ and $\mathrm{HNO}_{3}$ profiles inside the Arctic vortex from MIPAS-B limb emission spectra obtained during EASOE, Geophys. Res. Lett., 21, 1263-1266, https://doi.org/10.1029/93GL01303, 1994.

Parrish, A., Connor, B., Tsou, J., McDermid, I., and Chu, W.: Ground-based microwave monitoring of stratospheric ozone, J. Geophys. Res., 97, 2541-2546, 1992.

Pitts, M. C., Thomason, L. W., Poole, L. R., and Winker, D. M.: Characterization of Polar Stratospheric Clouds with spaceborne lidar: CALIPSO and the 2006 Antarctic season, Atmos. Chem. Phys., 7, 5207-5228, https://doi.org/10.5194/acp-7-5207-2007, 2007.

Pitts, M. C., Poole, L. R., and Thomason, L. W.: CALIPSO polar stratospheric cloud observations: second-generation detection algorithm and composition discrimination, Atmos. Chem. Phys., 9, 7577-7589, https://doi.org/10.5194/acp-9-7577-2009, 2009.

Pitts, M. C., Poole, L. R., Dörnbrack, A., and Thomason, L. W.: The 2009-2010 Arctic polar stratospheric cloud season: a CALIPSO perspective, Atmos. Chem. Phys., 11, 2161-2177, https://doi.org/10.5194/acp-11-2161-2011, 2011.

Rees, D., Barnett, J. J., and Labitzke, K.: COSPAR International Reference Atmosphere: 1986, Part II, Middle Atmosphere Models, Adv. Space Res., 10, 1-525, 1990.

Rinsland, C. P., Goldman, A., Murcray, F. J., Murcray, F. H., Blatherwick, R. D., and Murcray, D. G.: Infrared measurements of atmospheric gases above Mauna Loa, Hawaii, in February 1987, J. Geophys. Res., 93, 12607-12626, 1988.

Rinsland, C. P., Jones, N. B., Connor, B. J., Logan, J. A., Pougatchev, N. S., Goldman, A., Murcray, F. J., Stephen, T. M., Pine, A. S., Zander, R., Mahieu, E., and Demoulin, P.: Northern and Southern Hemisphere ground-based infrared spectroscopic measurements of tropospheric carbon monoxide and ethane, J. Geophys. Res., 103, 28197-28218, 1998.

Rodgers, C. D.: Inverse methods for atmospheric sounding: Theory and practice, World Scientific, Singapore, 2000.

Saitoh, N., Hayashida, S., Sugita, T., Nakajima, H., Yokota, T., Hayashi, M., Shiraishi, K., Kanzawa, H., Ejiri, M. K., Irie, H., Tanaka, T., Terao, Y., Bevilacqua, R. M., Randall, C. E., Thomason, L. W., Taha, G., Kobayashi, H., and Sasano, Y.: Intercomparison of ILAS-II version 1.4 aerosol extinction coefficient at $780 \mathrm{~nm}$ with SAGE II, SAGE III, and POAM III, J. Geophys. Res., 111, D11S05, https://doi.org/10.1029/2005JD006315, 2006.

Sander, S. P., Abbatt, J., Barker, J. R., Burkholder, J. B., Friedl, R. R., Golden, D. M., Huie, R. E., Kolb, C. E., Kurylo, M. J., Moortgat, G. K., Orkin, V. L., and Wine, P. H.: Chemical Kinetics and Photochemical Data for Use in Atmospheric Studies, Evaluation No. 17, JPL Publication 10-6, Jet Propulsion Laboratory, Pasadena, available at: http://jpldataeval.jpl.nasa.gov/ (last access: 21 January 2020), 2011.

Santee, M. L., Manney, G. L., Waters, J. W., and Livesey, N. J.: Variations and climatology of $\mathrm{ClO}$ in the polar lower stratosphere from UARS Microwave Limb Sounder measurements, J. Geophys. Res., 108, 4454, https://doi.org/10.1029/2002JD003335, 2003.

Santee, M. L., MacKenzie, I. A., Manney, G. L., Chipperfield, M. P., Bernath, P. F., Walker, K. A., Boone, C. D., Froidevaux, L., Livesey, N. J., and Waters, J. W.: A study of stratospheric chlorine partitioning based on new satellite 
measurements and modeling, J. Geophys. Res., 113, D12307, https://doi.org/10.1029/2007JD009057, 2008.

Santee, M. L., Manney, G. L., Livesey, N. J., Froidevaux, L., Schwartz, M. J., and Read, W. G.: Trace gas evolution in the lowermost stratosphere from Aura Microwave Limb Sounder measurements, J. Geophys. Res., 116, D18306, https://doi.org/10.1029/2011JD015590, 2011.

Schauffler, S. M., Atlas, E. L., Donnelly, S. G., Andrews, A., Montzka, S. A., Elkins, J. W., Hurst, D. F., Romashkin, P. A., Dutton, G. S., and Stroud, V.: Chlorine budget and partitioning during the Stratospheric Aerosol and Gas Experiment (SAGE) III Ozone Loss and Validation Experiment (SOLVE), J. Geophys. Res., 108, 4173, https://doi.org/10.1029/2001JD002040, 2003.

Schneider, M., Hase, F., Blumenstock, T., Redondas, A., and Cuevas, E.: Quality assessment of $\mathrm{O}_{3}$ profiles measured by a state-of-the-art ground-based FTIR observing system, Atmos. Chem. Phys., 8, 5579-5588, https://doi.org/10.5194/acp-8-55792008, 2008.

Smit, H. G. J. and Straeter, W.: JOSIE-2000, Jülich Ozone Sonde Intercomparison Experiment 2000, The 2000 WMO international intercomparison of operating procedures for ECC-ozone sondes at the environmental simulation facility at Jülich, WMO Global Atmosphere Watch report series, No. 158, World Meteorological Organization, Geneva, 2004.

Solomon, S.: Stratospheric ozone depletion: A review of concepts and history, Rev. Geophys., 37, 275-316, https://doi.org/10.1029/1999RG900008, 1999.

Solomon, S., Garcia, R. R., Rowland, F. S., and Wuebbles, D. J.: On the depletion of Antarctic ozone, Nature, 321, 755-758, 1986.

Solomon, S., Mount, G. H., Sanders, R. W., and Schmeltekopf, A. L.: Visible spectroscopy at McMurdo Station, Antarctica, 2. Observations of OClO, J. Geophys. Res., 92, 8329-8338, 1987.

Solomon, S., Kinnison, D., Bandoro, J., and Garcia, R.: Simulation of polar ozone depletion: An update, J. Geophys. Res., 120, 7958-7974, https://doi.org/10.1002/2015JD023365, 2015.

Solomon, S., Ivy, D. J., Kinninson, D., Mills, M. J., Neely III, R. R., and Schmidt, A.: Emergene of healing in the Antarctic ozone layer, Science, 353, 269-274, https://doi.org/10.1126/science.aae0061, 2016.

SPARC CCMVal: SPARC Report on the Evaluation of ChemistryClimate Models, edited by: Eyring, V., Shepherd, T. G., and Waugh, D. W., SPARC Report No.5, WCRP-132, WMO/TDNo. 1526, World Climate Research Program, International Council for Science, 2010.

Strahan, S. E., Douglass, A. R., Newman, P. A., and Steenrod, S. D.: Inorganic chlorine variability in the Antarctic vortex and implications for ozone recovery, J. Geophys. Res.-Atmos., 119, 1409814109, https://doi.org/10.1002/2014JD022295, 2014.

Sugita, T., Nakajima, H., Yokota, T., Kanzawa, H., Gernandt, H., Herber, A., von der Gathen, P., König-Langlo, G., Sato, K., Dorokhov, V., Yushkov, V. A., Murayama, Y., Yamamori, M., Godin-Beekmann, S., Goutail, F., Roscoe, H. K., Deshler, T., Yela, M., Taalas, P., Kyrö, E., Oltmans, S. J., Johnson, B. J., Allaart, M., Litynska, Z., Klekociuk, A., Andersen, S. B., Braathen, G. O., De Backer, H., Randall, C. E., Bevilacqua, R. M., Taha, G., Thomason, L. W., Irie, H., Ejiri, M. K., Saitoh, N., Tanaka, T., Terao, Y., Kobayashi, H., and Sasano, Y.: Ozone profiles in the high-latitude stratosphere and lower mesosphere measured by the Improved Limb Atmo- spheric Spectrometer (ILAS)-II: Comparison with other satellite sensors and ozonesondes, J. Geophys. Res., 111, D11S02, https://doi.org/10.1029/2005JD006439, 2006.

Tilmes, S., Müller, R., Grooß, J.-U., Nakajima, H., and Sasano, Y.: Development of tracer relations and chemical ozone loss during the steup phase of the polar vortex, J. Geophys. Res., 111, D24S90, https://doi.org/10.1029/2005JD006726, 2006.

Tomikawa, Y. and Sato, K.: Trapped waves in the edge region of stratospheric polar vortices, J. Geophys. Res., 108, 4047, https://doi.org/10.1029/2002JD002579, 2003.

Tomikawa, Y., Sato, K., Hirasawa, N., Tsutsumi, M., and Nakamura, T.: Balloon-borne observations of lower stratospheric water vapor at Syowa Station, Antarctica in 2013, Polar Sci., 9, 345353, https://doi.org/10.1016/j.polar.2015.08.003, 2015.

Tuck, A. F., Kelly, K. K., Webster, C. R., Loewenstein, M., Stimpfle, R. M., Proffitt, M. H., and Chan, R. K.: Airborne chemistry and dynamics at the edge of the 1994 Antarctic vortex, J. Chem. Soc. Faraday T., 91, 3063-3071, 1995.

von Clarmann, T. and Johansson, S.: Chlorine nitrate in the atmosphere, Atmos. Chem. Phys., 18, 15363-15386, https://doi.org/10.5194/acp-18-15363-2018, 2018.

von Clarmann, T., Fischer, H., Friedl-Vallon, F., Linden, A., Oelhaf, H., Piesch, C., Seefeldner, M., and Völker, W.: Retrieval of stratospheric $\mathrm{O}_{3}, \mathrm{HNO}_{3}$, and $\mathrm{ClONO}_{2}$ profiles from 1992 MIPAS-B limb emission spectra: method, results and error analysis, J. Geophys. Res., 98, 20495-20506, 1993.

von Clarmann, T., Glatthor, N., Grabowski, U., Höpfner, M., Kellmann, S., Kiefer, M., Linden, A., Tsidu, G. M., Milz, M., Steck, T., Stiller, G. P., Wand, D. Y., and Fischer, H.: Retrieval of temperature and tangent altitude pointing from limb emission spectra recorded from space by the Michelson Interferometer for Passive Atmospheric Sounding (MIPAS), J. Geophys. Res., 108, 4736, https://doi.org/10.1029/2003JD003602, 2003.

Waters, J. W., Froidevaux, L., Harwood, R. S., Jarnot, R. F., Pickett, H. M., Read, W. G., Siegel, P. H., Cofield, R. E., Filipiak, M. J., Flower, D. A., Holden, J. R., Lau, G. K., Livesey, N. J., Manney, G. L., Pumphrey, H. C., Santee, M. L., Wu, D. L., Cuddy, D. T., Lay, R. R., Loo, M. S., Perun, V. S., Schwartz, M. J., Stek, P. C., Thurstans, R. P., Boyles, M. A., Chandra, K. M., Chavez, M. C., Chen, G.-S., Chudasama, B. V., and Dodge, R.: The Earth Observing System Microwave Limb Sounder (EOS MLS) on the Aura satellite, IEEE T. Geosci. Remote Sens., 44, 1075-1092, 2006.

Wegner, T., Grooß, J.-U., von Hobe, M., Stroh, F., SumińskaEbersoldt, O., Volk, C. M., Hösen, E., Mitev, V., Shur, G., and Müller, R.: Heterogeneous chlorine activation on stratospheric aerosols and clouds in the Arctic polar vortex, Atmos. Chem. Phys., 12, 11095-11106, https://doi.org/10.5194/acp-12-110952012, 2012.

Winker, D. M., McGill, M., and Hunt, W. H.: Initial performance assessment of CALIOP, Geophys. Res. Lett., 34, L19803, https://doi.org/10.1029/2007GL030135, 2007.

WMO: Scientific Assessment of Ozone Depletion: 2006, Global Ozone Research and Monitoring Project - Report No. 50, 572 pp., Geneva, Switzerland, 2007.

WMO: Scientific Assessment of Ozone Depletion: 2010, Global Ozone Research and Monitoring Project - Report No. 52, 516 pp., Geneva, Switzerland, 2011. 
WMO: Scientific Assessment of Ozone Depletion: 2014, Global Ozone Research and Monitoring Project - Report No. 55, 416 pp., Geneva, Switzerland, 2014.

WMO: Scientific Assessment of Ozone Depletion: 2018, Global Ozone Research and Monitoring Project - Report No. 58, 590 pp., Geneva, Switzerland, 2019.

Wood, S. W., Bodeker, G. E., Boyd, I. S., Jones, N. B., Connor, B. J., Johnston, P. V., Matthews, W. A., Nichol, S. E., Murcray, F. J., Nakajima, H., and Sasano, Y.: Validation of version 5.20 ILAS $\mathrm{HNO}_{3}, \mathrm{CH}_{4}, \mathrm{~N}_{2} \mathrm{O}, \mathrm{O}_{3}$, and $\mathrm{NO}_{2}$ using ground-based measurements at Arrival Heights and Kiruna, J. Geophys. Res., 107, 8208, https://doi.org/10.1029/2001JD000581, 2002.

Wood, S. W., Batchelor, R. L., Goldman, A., Rinsland, C. P., Connor, B. J., Murcray, F. J., Stephen, T. M., and Heuff, D. N.: Ground-based nitric acid measurements at Arrival Heights, Antarctica, using solar and lunar Fourier transform infrared observations, J. Geophys. Res., 109, D18307, https://doi.org/10.1029/2004JD004665, 2004.
Yang, E.-S., Cunnold, D. M., Newchurch, M. J., Salawitch, R. J., McCormick, M. P., Russell III, J. M., Zawodny, J. M., and Oltmans, S. J.: First stage of Antarctic ozone recovery, J. Geophys. Res., 113, D20308, https://doi.org/10.1029/2007JD009675, 2008.

Ziemke, J. R., Chandra, S., Labow, G. J., Bhartia, P. K., Froidevaux, L., and Witte, J. C.: A global climatology of tropospheric and stratospheric ozone derived from Aura OMI and MLS measurements, Atmos. Chem. Phys., 11, 9237-9251, https://doi.org/10.5194/acp-11-9237-2011, 2011. 